\title{
Wind Resource Assessment: San Nicolas Island, California
}

Ed McKenna

National Renewable Energy Laboratory

Timothy L. Olsen

Timothy L. Olsen Consulting

NREL technical monitor: Ed McKenna

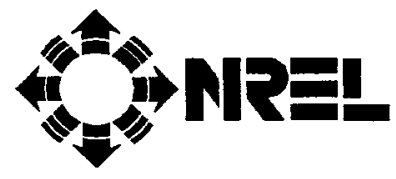

National Renewable Energy Laboratory 1617 Cole Boulevard Golden, Colorado 80401-3393 A national laboratory of the U.S. Department of Energy Managed by Midwest Research Institute for the U.S. Department of Energy under contract No. DE-AC36-83CH10093

Prepared under Subcontract No. CCD-5-15223

January 1996 


\section{NOTICE}

This report was prepared as an account of work sponsored by an agency of the United States govemment. Neither the United States government nor any agency thereof, nor any of their employees, makes any warranty, express or implied, or assumes any legal liability or responsibility for the accuracy, completeness, or usefulness of any information, apparatus, product, or process disclosed, or represents that its use would not infringe privately owned rights. Reference herein to any specific commercial product, process, or senvice by trade name, trademark, manufacturer, or otherwise does not necessarily constitute or imply its endorsement, recommendation, or favoring by the United States government or any agency thereof. The views and opinions of authors expressed herein do not necessarily state or reflect those of the United States govemment or any agency thereof.

Available to DOE and DOE contractors from:

Office of Scientific and Technical Information (OSTI)

P.O. Box 62

Oak Ridge, TN 37831

Prices available by calling (615) $576-8401$

Available to the public from:

National Technical Information Service (NTIS)

U.S. Department of Commerce

5285 Port Royal Road

Springfield, VA 22161

(703) $487-4650$ 


\section{$\underline{\text { Page }}$}

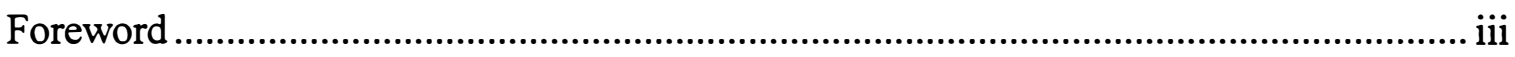

Acknowledgments.................................................................................................... iv

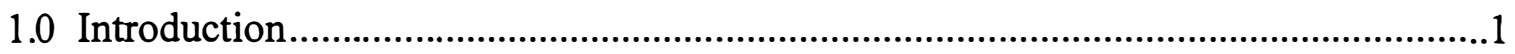

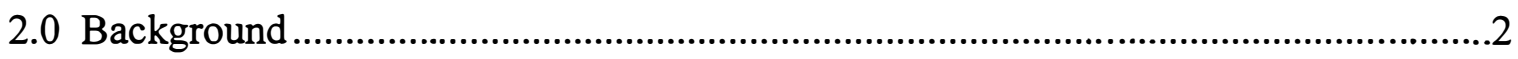

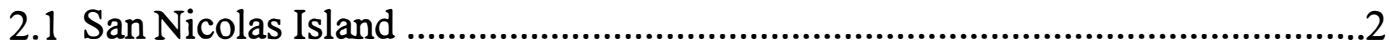

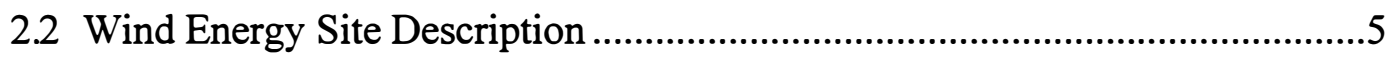

2.3 Wind Data Collection And Analysis..................................................................

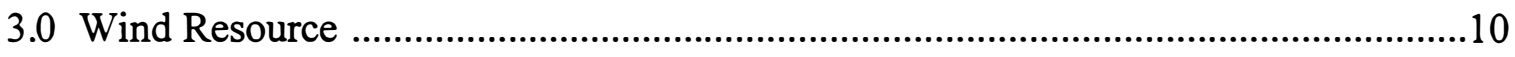

3.1 Historical Data .......................................................................................

3.2 Current Data Statistics .................................................................................12

3.3 Annual Meteorological Records ..................................................................13

3.4 Annual Average Diumal Wind Speed ..........................................................16

3.5 Prevailing Wind Direction ..........................................................................

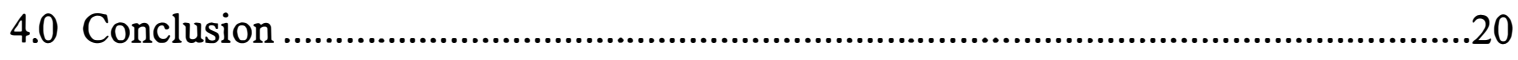

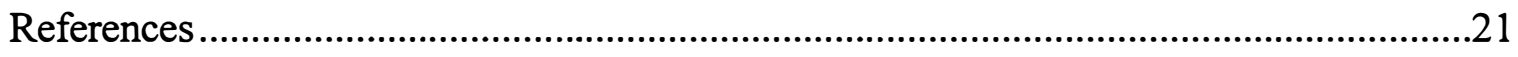

Appendix A: Daily Wind Speed Records

Appendix B: Monthly Wind Speed Records

Appendix C: Monthly Average Diumal Wind Speeds 


\section{List of Tables}

Page

1. Meteorological Instrumentation, San Nicolas Island ............................................

2. Sensor Accuracy and Precision, San Nicolas Island..............................................

3. Summary of Current SNI Meteorological Data ......................................................11

\section{List of Figures}

Page

1. San Nicolas Island Location Map .....................................................................

2. San Nicolas Island Topographic Map ...................................................................

3. SNI Facilities and Potential Wind Farm Site .......................................................

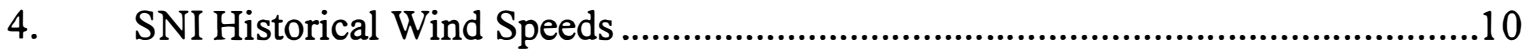

5. SNI Wind Speed Frequency Distribution .........................................................12

6. Annual Wind Speed Record......................................................................13

7. Annual Temperature Record..........................................................................14

8. Annual Pressure Record..............................................................................

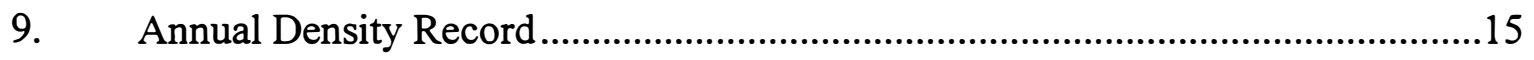

10. Annual Power Density Record.....................................................................15

11. Annual Average Diumal Wind Speed ...................................................................16

12. Wind Rose: Percent Time ………………….............................................

13. Wind Rose: Average Wind Speed …………....................................................18

14. Wind Rose: Time Weighted Average Wind Speed ............................................19 


\section{FOREWORD}

This joint Department of Energy (DOE) and National Renewable Energy Laboratory (NREL) report was prepared as an account of work for others funding contract, sponsored by the Department of Defense (DoD) Strategic Environmental Research and Development Program (SERDP) under DOE Contract \# DE-AC02-83CH10093.

This report documents the wind resources on San Nicolas Island (SNI) from detailed field measurements collected for one year and coarse historical data collected over 32 years. This report will be used by DoD/ United States Navy (USN) Naval Facilities Engineering Service Center (NFESC) as input for additional economic and feasibility studies for a Wind-Diesel installation for SNI.

Timothy L. Olsen, Engineering Consultant, was contracted to provide data reduction analysis, research historical wind resource data, and assist with generation of this report. 


\section{ACKNOWLEDGMENTS}

The authors wish to acknowledge major contributions to the success of this project by Bob Keller, Bill Gage, and Sherwin West of Mountain Valley Energy, who helped to install, commission, and operate the meteorological test equipment. Sherwin West also helped collect and process large quantities of wind resource data. Neil Kelley of NREL shared his excellent meteorological advice and guidance in presentation and interpretation of the wind resource data. Sue Hansen of Sandia National Laboratories tracked down and furnished old reports on San Nicolas Island (SNI) wind resources. Dennis Elliott and Marc Schwartz of NREL helped us track down historical site data. Ron Vincent of NFESC, the SNI project manager, advised on all aspects of SNI facilities, costs, and operations. Lieutenant Commander Egeln, USN Officer in Charge for San Nicolas Island and USN Point Mugu Energy and Public Works Center (PWC) office made the site available for study and arranged travel to and from SNI. Scott Miller of NFESC assisted with instrumentation, and the rest of the SNI Navy support staff assisted with this project in countless ways. Kristin Olsen of KO Consulting organized, edited, and typed the report and developed and refined its numerous graphs. Each of these people deserves special thanks for their role in bringing this project together. 


\subsection{INTRODUCTION}

This report presents an assessment of the local wind resource on San Nicolas Island(SNI), California. In section 2.0, SNI and its potential wind energy site are described, as well as the data collection and analysis procedures. Section 3.0 presents the wind resource data and its analysis results, including historical wind speed averages, current annual and monthly records, diumal wind speeds, and annual wind roses. Conclusions about the SNI wind resource are presented in section 4.0 . 


\subsection{BACKGROUND}

\subsection{San Nicolas Island}

San Nicolas Island (SNI) is the site of the Navy Range Instrumentation Test Site which relies on an isolated diesel-powered grid for its energy needs. As shown in Figure 1, the island is located in the Pacific Ocean 85 miles southwest of Los Angeles, California and 65 miles south of the Naval Air Weapons Station (NAWS), Point Mugu, California. SNI is situated on the continental shelf at latitude $\mathrm{N} 33^{\circ} 14^{\prime}$ and longitude W1 $19^{\circ} 27^{\prime}$. It is approximately 9 miles long and 3.6 miles wide and encompasses an area of 13,370 acres of land owned by the Navy in fee title [1].

The island, generally treeless, is relatively flat on top and drops sharply off on the south side with a more gradual slope to the ocean on the north side. The island's shoreline is formed by cliffs. The interior terrain is a rolling mesa, extensively eroded with little vegetation, mostly coarse grasses and few large shrubs. Its highest point is 907 feet high. The western end contains large shifting sand dunes, and the eastern end has a large sand spit extending eastward. Cliffs on the southern side of the island rise sharply from the sea to 700 feet within a mile of shore; cliffs on the northern side of the island rise to the mesa at 300-400 feet above sea level [1]. A topographic map of the island is shown in Figure 2.

The average mean monthly temperature on SNI is $15^{\circ} \mathrm{C}\left(59^{\circ} \mathrm{F}\right)$. In general, daily maximum temperatures vary from 16 to $21^{\circ} \mathrm{C}\left(60\right.$ to $\left.70^{\circ} \mathrm{F}\right)$, and daily minimum temperatures vary from 9 to $14^{\circ} \mathrm{C}\left(48\right.$ to $\left.58^{\circ} \mathrm{F}\right)$. The coolest month is usually January, and the warmest month is usually September. No freezing temperatures have been recorded on SNI, but temperatures over $38^{\circ} \mathrm{C}$ $\left(100^{\circ} \mathrm{F}\right)$ have been recorded several times. Precipitation averages only $20.1 \mathrm{~cm}$ ( 7.91 inches $)$ per year, and $86 \%$ of the rain falls from November through February. The relative humidity ranges from $57 \%$ to $100 \%$.

Winds on San Nicolas are prevailingly northwest and are strong most of the year. The average wind speed is $7.2 \mathrm{~m} / \mathrm{s}(14 \mathrm{knots})$ and seasonal variation is small. The windiest months, March through July, have wind speeds averaging $8.2 \mathrm{~m} / \mathrm{s}$ (16 knots). The least windy months, August through February, have wind speeds averaging $6.2 \mathrm{~m} / \mathrm{s}$ (12 knots)

Much of San Nicolas Island is used as the Navy Range Instrumentation Test Site. The island is equipped with facilities supporting metric radar, telemetry, Extended Area Test System, optics, communications, microwave, missile launching, drone launching, surveillance radar, and target control. The main support facilities include a runway, an air terminal, housing, a power plant, a fuel farm, a reverse osmosis water system, and a public works and transportation building [1]. 


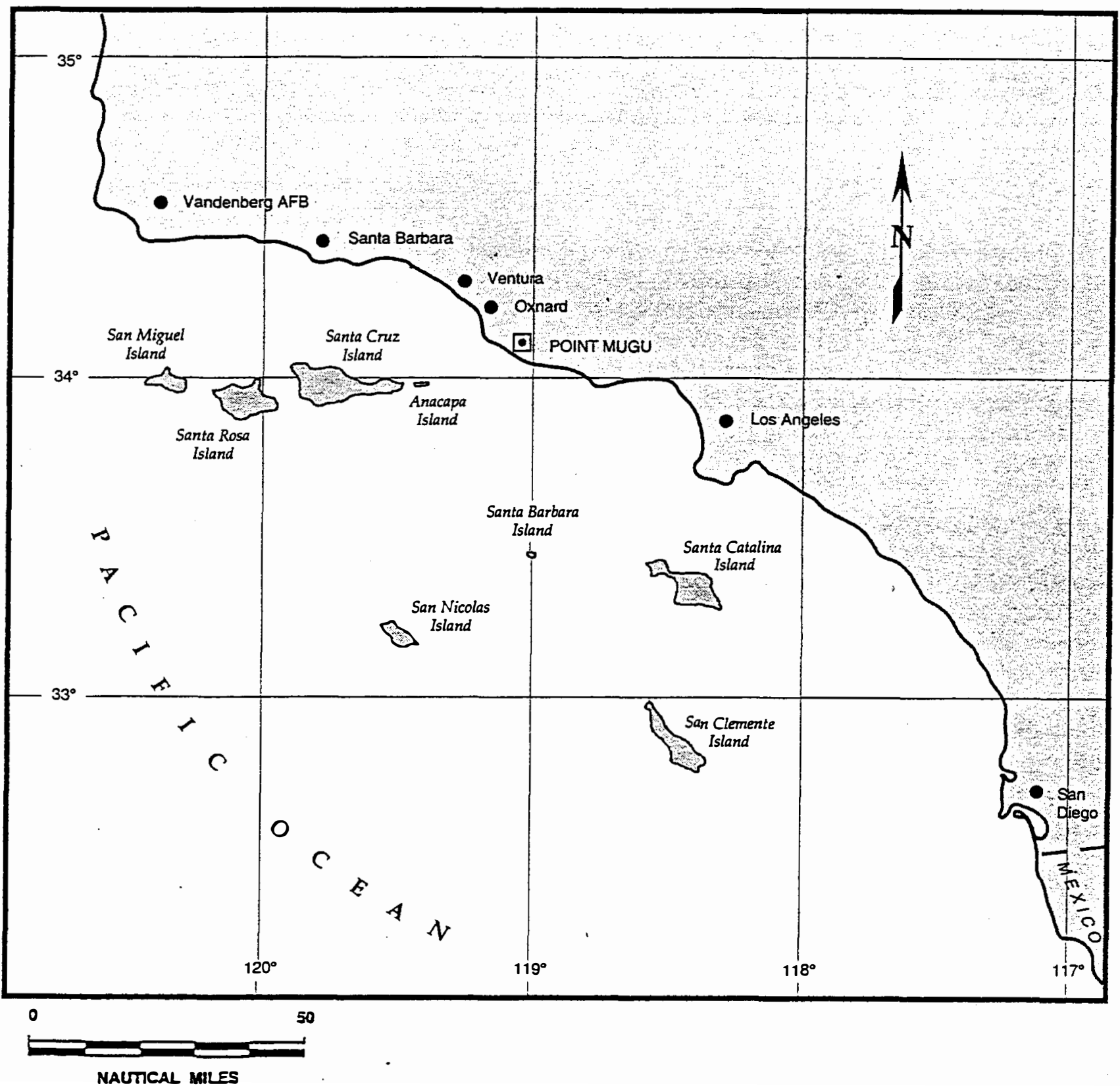

Figure 1. San Nicolas Island location map Source: San Nicholas Island Site Manual. 


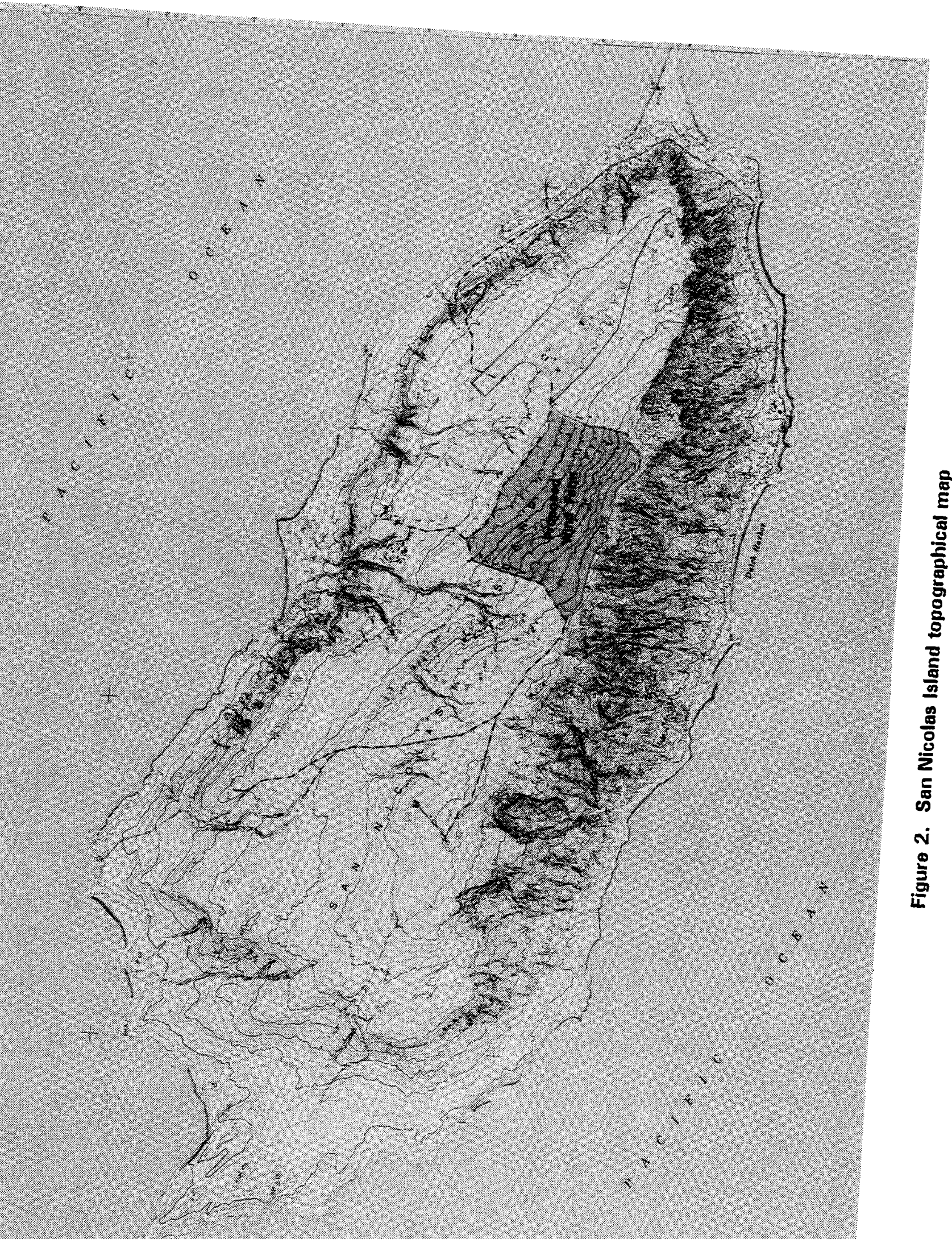




\subsection{Wind Energy Site Description}

The wind energy site is located east-southeast of the center of the island, west of the airport, and along the island's crest, as shown in Figure 3 . About $1.7 \mathrm{sq} . \mathrm{km}$ (0.7 sq. mi.) in area, the site is the west portion of the quadrant bounded by Harrington Road, Owens Road and Monroe Drive. The highest elevation, 818 feet, occurs along Harrington Road toward Owens Road, from which the terrain slopes down to the north and northeast to 550 feet near Monroe Drive.

There are no trees or other wind obstructions on the site, just light vegetation including grasses and cacti. Parts of the site are very eroded and will require some fill and stabilization. Several low water tanks and buildings including the Power Plant Island Utilities are located upwind. The nearness of the power plant minimizes power line distances to the wind energy site.

This site has energetic winds year round. Although more optimal wind site locations may exist on the island, this particular site was selected so as not to interfere with radar, communications, and other naval operations, and to create minimum environmental and cultural impacts. 


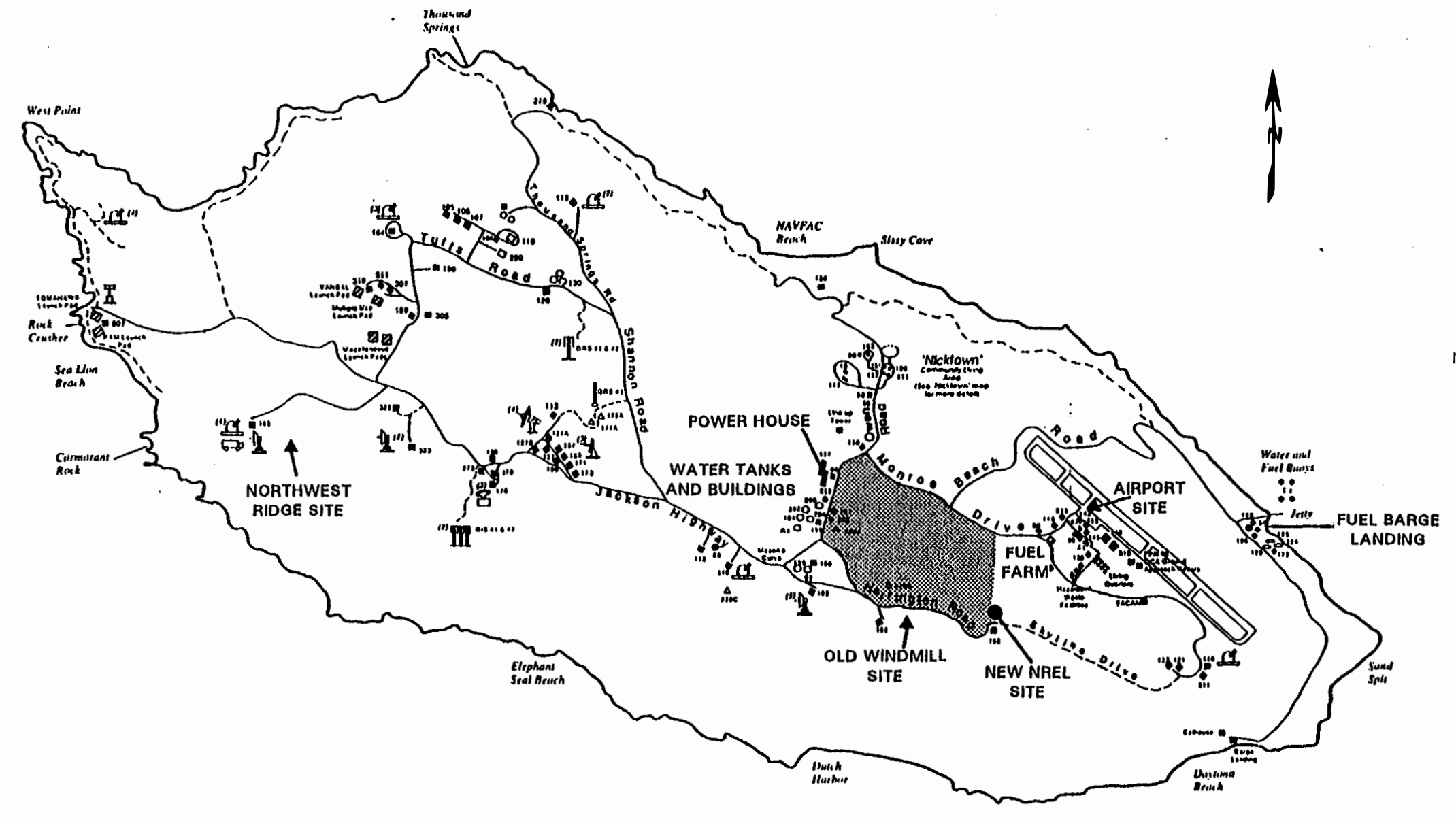

\section{LEGEND}

Potential Windfarm Site

- Historical Monitoring Site

- New Monitoring Site

Figure 3. San Nicolas Island Naval Facilities and potential windfarm area Source: San Nicholas Island Site Manual. 


\subsection{Wind Data Collection and Analysis}

In July 1994, NREL entered into a cooperative agreement with NFESC to collect one full year of high quality wind energy resource data at SNI. We examinated this data in detail, and reviewed historical summary data in order to describe long term behavior.

Instrumentation: The new data was collected through a full wind-energy meteorological sensor system including two anemometers, two wind vanes, a temperature probe, and a barometer. The sensors were mounted $30.5 \mathrm{~m}(100 \mathrm{ft})$ high atop Facility No. 186, the FIC Communications Tower. Details of the instrumentation are presented in Table 1.

Data collection: Data collection began 14 July 1994, and the full year used in this study ran from 1 August 1994 (0000 hours) to 1 August 1995 (0000 hours). All data was sampled at $1 \mathrm{~Hz}$ and then stored as 2 -minute and 10-minute averages. The 10-minute average data was used for this report.

Data analysis: Daily records of the 10-minute average wind speed are plotted for the full year in Appendix A. The annual records use monthly data averages, and the monthly records use daily averages. An annual record is derived for air density using

$$
\rho=p /\left(R^{*} T\right)
$$

where $\rho$ is density, $p$ is pressure, $T$ is temperature, and $\mathrm{R}=0.286 \mathrm{~kJ} /\left(\mathrm{kg}^{*} \mathrm{~K}\right)$ for air. Then wind power density is derived using

$$
\mathrm{P} / \mathrm{A}=0.5 * \rho * \mathrm{~V}^{3}
$$

where $\mathrm{P}$ is power, $\mathrm{A}$ is area, and $\mathrm{V}$ is wind speed. Using hourly average data, the diurnal wind speeds are created by computing an average for each hour of the day over all days in the period.

Wind direction data is difficult to present because the most common directions do not necessarily have the strongest winds. Therefore, this report includes three types of wind roses (in section 3.7): percent time at each direction, average wind speed at each direction, and time-weighted average wind speed at each direction.

Uncertainty Analysis: Measurement precision and accuracy are shown for each sensor and the data logger in Table 2. For air density and power density these values are derived from their corresponding source channels using the square root of the sum of the squares $[2,3]$. 
Figure 4: Meteorological Instrumentation, San Nicolas Island

\begin{tabular}{|c|c|c|c|c|c|c|c|}
\hline & & & & & NREL QA Code & & San Nicolas Island, CA. \\
\hline Manufacturer & Tag No & Description & Model & Serial & Calibration Date & Cost \$ & SNI Site \#1 \\
\hline AIR & & & & & & & Returned to NREL $7 / 14 / 94 \mathrm{Ed}$ \\
\hline AIR & $n / a$ & Intellisensor II 800-1060 mb Barometer & $A B-2 A$ & 4E0029 & Factory - 05/20/94 & $\$ 695$ & SNI Tower Base ENC 16/18 \\
\hline Campbell Sclentlfic & $02104 \mathrm{C}$ & Data Acquisition \& Control System [MET] & CR-10 & 08178 & Factory, 4/22/94 & $\$ 1,090$ & SNI Tower Base ENC 16/18 \\
\hline Campbell Scientific & $\mathbf{n} / \mathbf{a}$ & CR10KD Bracket Kit & 6226 & 0000 & NCR & $\$ 16$ & SNI Tower Base ENC 16/18 \\
\hline Campbell Scientific & $\mathrm{n} / \mathbf{a}$ & SM-716 Mounting Bracket & 6234 & 0000 & NCR & $\$ 18$ & SNI Tower Base ENC 16/18 \\
\hline Campbell Scientific & $n / a$ & Temperature Probe w/ 9 ft lead & $107-U$ & 0000 & NCR & $\$ 40$ & SNI 3m Base Temp Shield \\
\hline Campbell Scientific & $n / a$ & Solar Radiation Shield for $107-\mathrm{U}$ & 41301 & 0000 & NCR & $\$ 95$ & SNI 3m Base Temp Shield \\
\hline Campbell Scientific & $\mathrm{n} / \mathrm{a}$ & CR10 Wiring Panel & 8032 & 1984 & NCR & $\$ 210$ & SNI Tower Base ENC 16/18 \\
\hline Campbell Scientific & $n / a$ & 12 v Power Supply / w/charger & PS12LA & 0000 & NCR & $\$ 250$ & SNI Tower Base ENC 16/18 \\
\hline Campbell Scientific & $n / a$ & SOLAREX 10 Watt Solar Panel w/ mount & MSX 10 & JP93L21000083 & NCR & $\$ 250$ & SNI Tower Base w/ ENC 16/18 \\
\hline Campbell Scientific & $02200 C$ & CR10KD Keyboard / Display & CR-10 KO & 3853 & NCR & $\$ 275$ & SNI Tower Base ENC 16/18 \\
\hline Campbell Scientific & $n / a$ & Enclosure 16" $\times 18^{\prime \prime}$ & ENC 16/18 & 0000 & NCR & $\$ 300$ & SNI Tower Base ENC 16/18 \\
\hline Campbell Scientific & $n / a$ & Telephone Modem & DC112 & 6612 & NCR & $\$ 315$ & SNI Tower Base ENC 16/18 \\
\hline Campbell Scientific & $01529 \mathrm{C}$ & Storage Module "1" Extended Temp Range & SM-716 & 1379 & NCR & $\$ 750$ & SNI Tower Base ENC 16/18 \\
\hline Campbell Scientific & $01682 \mathrm{C}$ & Storage Module " 2" Extended Temp Range & SM-716 & 1772 & NCR & $\$ 750$ & Module \# 2 left w/ S.Miller NFESC \\
\hline Campbell Scientific & $\mathbf{n} / \mathbf{a}$ & 9-Pin Peripheral to RS-232 Interface & SC-532 & \begin{tabular}{|l|}
4776 \\
\end{tabular} & NCR & $\$ 180$ & NFESC -- Scott Miller Computer \\
\hline Campbell Scientific & $n / a$ & External Power Cable & PS12 & $\# 6186 /$ LT\#512410 & NCR & & SNI Tower Base ENC 16/18 \\
\hline & & Max vol $=30 v, \quad I s c=0.65 \mathrm{~A}$ & & 0000 & & & \\
\hline & & $100 \mathrm{ft}$ Wind Sensor System "A" & WS.201 J & & & $\$ 1,400$ & \\
\hline Met One Instruments & $n / a$ & Wind Direction Sensor, W/D "A" & SD-201 & 488 & Factory $6 / 1 / 94$ & & SNI Tower Mast / Boom Assy \\
\hline Met One Instruments & $n / a$ & Wind Direction Vane Assembly & V-201 & N/A & NCR & & SNI Tower Mast / Boom Assy \\
\hline Met One Instruments & $n / a$ & Wind Speed Sensor, W/S "A" & SS-201 & N3315 & Factory 6/1/94 & & SNI Tower Mast / Boom Assy \\
\hline Met One Instruments & $n / a$ & Match w/ Cup & C-201 & N3315 & NCR & & SNI Tower Mast / Boom Assy \\
\hline Met One Instruments & $n / a$ & Wired Crossarm (with connectors) & CA-201 & N/A & NCR & & SNI Tower Mast / Boom Assy \\
\hline Met One Instruments & $n / a$ & Junction Box & JB-201-A & N/A & NCR & & SNI Tower Mast / Boom Assy \\
\hline & & '100 ft Wind Sensor System "B" & WS-201 J & & & $\$ 1.400$ & \\
\hline Met One Instruments & $n / a$ & Wind Direction Sensor, W/D "B" & SD-201 & 489 & Factory 6/1/94 & & SNI Tower Mast / Boom Assy \\
\hline Met One Instruments & $n / a$ & Wind Direction Sensor, W/D "B" Replacement & SD-201 & MetOne & Factory 10/1/94 & $\$ 500$ & Sensor shipped to S.Miller NFESC \\
\hline Met One Instruments & $\mathrm{n} / \mathrm{a}$ & Wind Direction Vane Assembly & V-201 & N/A & NCR & & SNI Tower Mast / Boom Assy \\
\hline Met One Instruments & $n / a$ & Wind Speed Sensor, W/S "B" & SS+201 & N3316 & Factory $6 / 1 / 94$ & & SNI Tower Mast / Boom Assy \\
\hline Met One Instruments & n/a & Match w/ Cup & C-201 & N3316 & NCR & & SNI Tower Mast / Boom Assy \\
\hline Met One Instruments & $n / a$ & Wired Crossarm (with connectors) & CA-201 & N/A & NCR & & SNI Tower Mast / Boom Assy \\
\hline Met One Instruments & $n / a$ & Junction Box & JB-201-A & N/A & NCR & & SNI Tower Mast / Boom Assy \\
\hline Met One Instruments & $\mathrm{n} / \mathrm{a}$ & $8 \mathrm{Ft}$. Retractable Instrument Boom Arm & SPEC & $\mathrm{n} / \mathrm{a}$ & NCR & $\$ 550$ & SNI Tower Mast / Boom Assy \\
\hline W/ NWTC & $n / a$ & $10 \mathrm{Ft}$. Retractable Mast Assy. & Keller & SPEC & NCR & $\$ 500$ & SNI Tower Mast / Boom Assy \\
\hline & & & & & TOTAL \$ & $\$ 9,584$ & SNI Tower Mast / Boom Assy \\
\hline
\end{tabular}


Figure 5: Sensor Accuracy and Precision,

San Nicolas Island

\begin{tabular}{|c|c|c|c|c|c|c|c|c|c|c|c|}
\hline & & & & & Factory & Precision & Precision & Accuracy & Accuracy & Range & Engr. \\
\hline Manufacturer & Tag No & Description & Model & Serial & Calib. Date & (EU) & (\% FS) & $(+/-\mathbf{E U})$ & (+/- \% FS) & & Units \\
\hline & & & & & & & & & & & \\
\hline Campbell Scientific & $02104 \mathrm{C}$ & CR-10 Analog Channels 1 thru 8 & CR-10 & 08178 & $4 / 22 / 94$ & $333 \mathrm{E}-6$ & 0.013 & & 0.05 & $2.5 \mathrm{vdc}$ & $\mathrm{vdc}$ \\
\hline Campbell Scientific & 02104C & CR-10 Pulse Channel 1 - 2 & CR-10 & 08178 & $4 / 22 / 94$ & 8-bit & 0.390 & 8-bit & & 2000 & $\mathrm{~Hz}$ \\
\hline Met One Instnunents & $\mathrm{n} / \mathbf{a}$ & Wind Speed Sensor, W/S "A" & SS-201 & N3315 & $6 / 1 / 94$ & & 0.390 & 0.500 & 2.00 & $0-90$ & $\mathrm{~m} / \mathrm{s}$ \\
\hline Met One Instruments & $\mathrm{n} / \mathbf{a}$ & Wind Direction Sensor, W/D "A" & SD-201 & 488 & 6/1/94 & & 0.013 & 3.600 & 1.00 & $0-360$ & deg. \\
\hline Met One Instruments & $\mathrm{n} / \mathbf{a}$ & Wind Speed Sensor, W/S "B" & SS-201 & N3316 & $6 / 1 / 94$ & & 0.390 & 0.500 & 2.00 & $0-90$ & $\mathrm{~m} / \mathrm{s}$ \\
\hline Met One Instruments & $\mathrm{n} / \mathrm{a}$ & Wind Direction Sensor, W/D "B" & SD-201 & 489 & $6 / 1 / 94$ & & 0.013 & 3.600 & 1.00 & $0-360$ & deg. \\
\hline Campbell Scientific & $\mathbf{n} / \mathbf{a}$ & Temperature Probe w/ $9 \mathrm{ft}$ lead & $107-U$ & 0000 & $6 / 1 / 94$ & 0.100 & 0.140 & 0.100 & 0.14 & -36 to +53 & $\operatorname{deg} C$ \\
\hline AIR & $\mathrm{n} / \mathbf{a}$ & Barometer $800-1060 \mathrm{mb}$ & AB-2A & 4E0029 & $6 / 1 / 94$ & 0.0635 & 0.024 & 0.500 & 0.19 & $800-1060$ & $\mathrm{hPa}$ \\
\hline Calculated & $\mathrm{n} / \mathbf{a}$ & Air Density & & & & 0.001 & 0.142 & 0.002 & 0.24 & $0.86-1.56$ & $\mathrm{~kg} / \mathrm{m}^{\wedge} 3$ \\
\hline Calculated & n/a & Power Density & & & & 3.920 & 0.690 & 19.700 & 3.47 & $0-569$ & $\mathrm{~W} / \mathrm{m}^{\wedge} 2$ \\
\hline
\end{tabular}




\subsection{WIND RESOURCE}

\subsection{Historical Data}

The wind resource at most sites varies from year to year and, in fact, it can vary widely. For this reason, it is prudent to review some long-term data at the nearest site available. Therefore, this section begins with a review of 32 years of wind speed data (1947-1978) at the SNI station number 93116 , compiled by Pacific Northwest Laboratories and managed by the National Climatic Data Center [4]. Newer data is not yet available.

The anemometer locations changed several times for this collection of historical wind data, and therefore had different sensors, mountings, heights, exposures, and possibly drifting calibrations. The heights varied from $4.6 \mathrm{~m}$ to $19.8 \mathrm{~m}$, so each year's data was adjusted to this study's measurement height $(30.5 \mathrm{~m})$ using the $1 / 7$ power law.

Readings generally were made 12-18 times a day - more often in the daytime -- thereby raising the possibility of skewing the averages with non-uniform intervals. Some bias toward lower wind speed measurements might be expected if more readings occurred in daytime, if unknown obstructions were present, or if old anemometers began to bind. Since these factors are not tractable, no attempt is made to account for them. The results of the historical wind speed data follow in Figure 4.

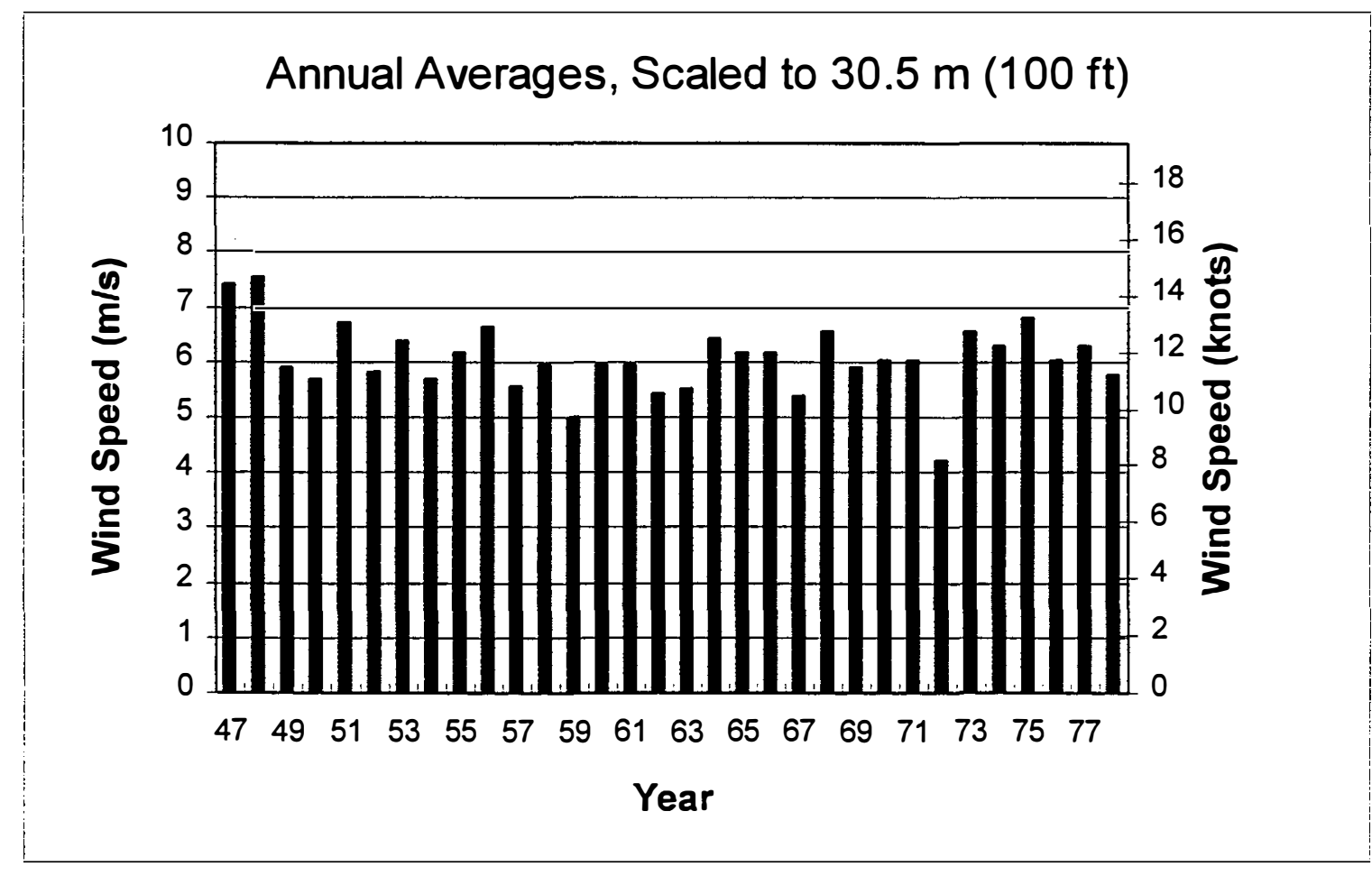

Figure 4: SNI Historical Wind Speeds 
Interannual Variability in The Wind Resource: It is important to realize that a single year of good wind data does not guarantee the same energy production each year. Examination of historical data will help to quantify the interannual variability. The 32 year average wind speed at $\mathrm{SNI}$ is $6.1 \mathrm{~m} / \mathrm{s}$ (11.8 knots) based on annual averages of hourly data, and the average of the annual standard deviations is $3.8 \mathrm{~m} / \mathrm{s}$ ( $7.4 \mathrm{knots})$. But the standard deviation of the annual averages is $0.6 \mathrm{~m} / \mathrm{s},(1.2 \mathrm{knots})$ giving a variability of $0.6 / 6.1=0.10$, or $10 \%$. Despite our low confidence in the average wind speed, this variability implies that the annual average wind speed will fall within $+/-30 \%$ (3 standard deviations) $99 \%$ of the time, assuming these values are normally distributed. This can seriously affect energy production, as power is proportional to wind speed cubed. As an example, a $10 \%$ change in wind speed will cause about a $30 \%$ change in power; a $30 \%$ change in wind speed can alter power by a factor of three. 


\subsection{Current Data Statistics}

Statistical analysis of the full year of NREL 10-minute data yields the results which follow in Table 3, and a full wind-speed distribution is presented in Figure 5.

Table 3: Summary of Current SNI Meteorological Data

\begin{tabular}{llrrrr} 
Channel & Units & Average & $\begin{array}{r}\text { Standard } \\
\text { Deviation }\end{array}$ & Minimum & Maximum \\
\hline Wind Speed & $\mathrm{m} / \mathrm{s}$ & 7.2 & 4.8 & 0.0 & 28.5 \\
Wind Speed & $\mathrm{knots}$ & 14.0 & 9.3 & 0.0 & 55.4 \\
Ambient Temperature & ${ }^{\circ} \mathrm{C}$ & 14.5 & 3.9 & 6.4 & 33.4 \\
Ambient Pressure & $\mathrm{mbar}$ & 983 & 4.6 & 965 & 997 \\
Air Density & $\mathrm{kg} / \mathrm{m}^{3}$ & 1.20 & 0.02 & 1.14 & 1.22 \\
Power Density & $\mathrm{W} / \mathrm{m}^{2}$ & 473 & 759 & 2.3 & 4010
\end{tabular}

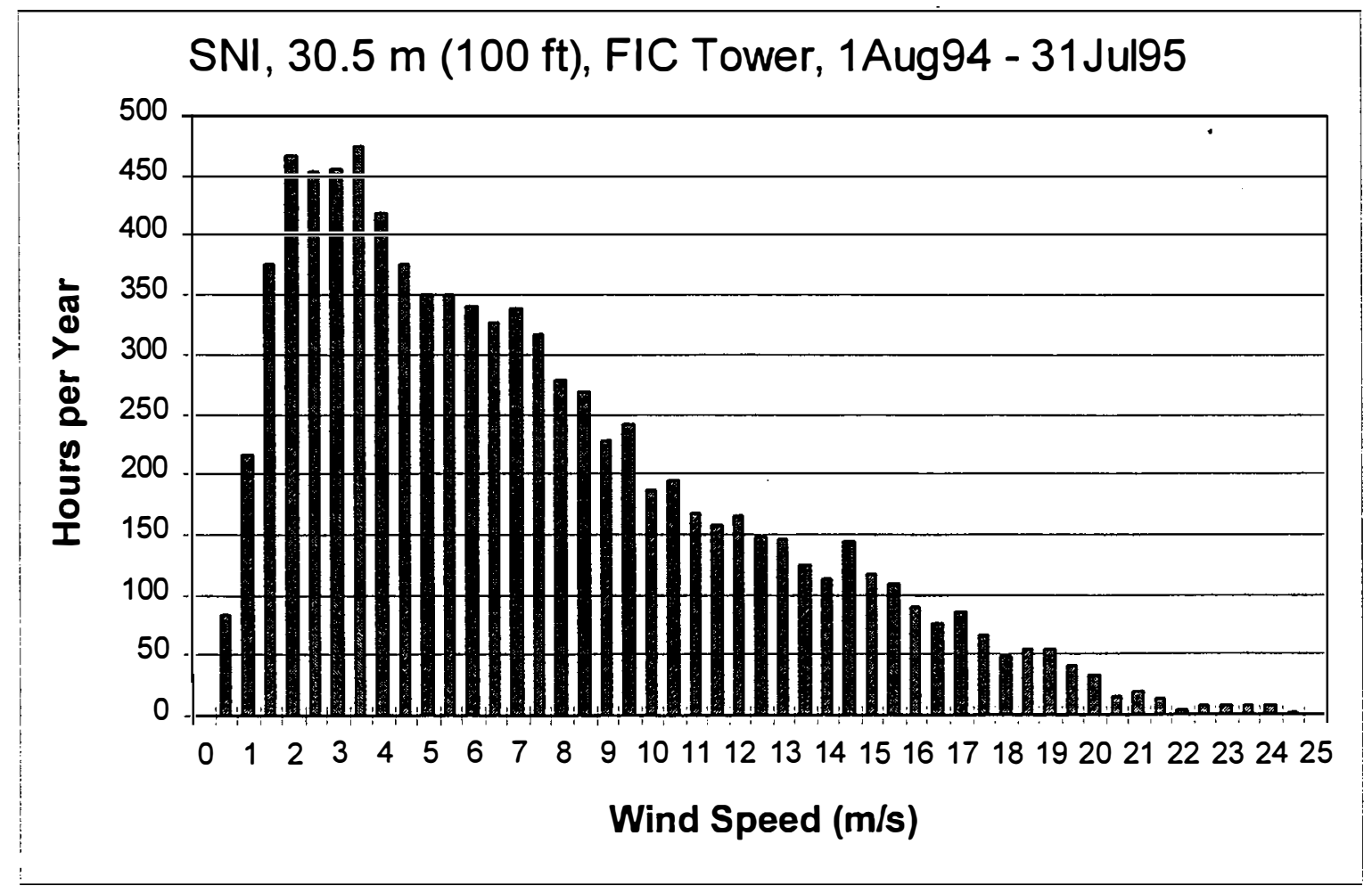

Figure 5: SNI Wind Speed Frequency Distribution 


\subsection{Annual Meteorological Records}

Annual records using monthly averages have been plotted for wind speed, ambient temperature, ambient pressure, air density, and power density. These plots appear in Figures 6-10. The source data was derived from NREL testing on SNI at $30.5 \mathrm{~m}$ (100 ft) on Facility No. 186 for the period 1 August 1994 through 31 July 1995. Wind speeds reached their highest monthly average $(10.3 \mathrm{~m} / \mathrm{s}, 20 \mathrm{knots})$ in April and lowest $(4.5 \mathrm{~m} / \mathrm{s}, 8.7 \mathrm{knots})$ in February, with near average levels the rest of the year. Temperature and pressure cycled gently with more warmth and lower pressure in the summer, causing slightly lower summer densities. Power density looks like an exaggeration of wind speed, as expected from its cubic relationship.

Monthly records using daily average wind speeds are shown in Appendix B for each month from August 1994 through July 1995. Daily records based on 10-minute average wind speeds appear in Appendix A, as mentioned earlier.

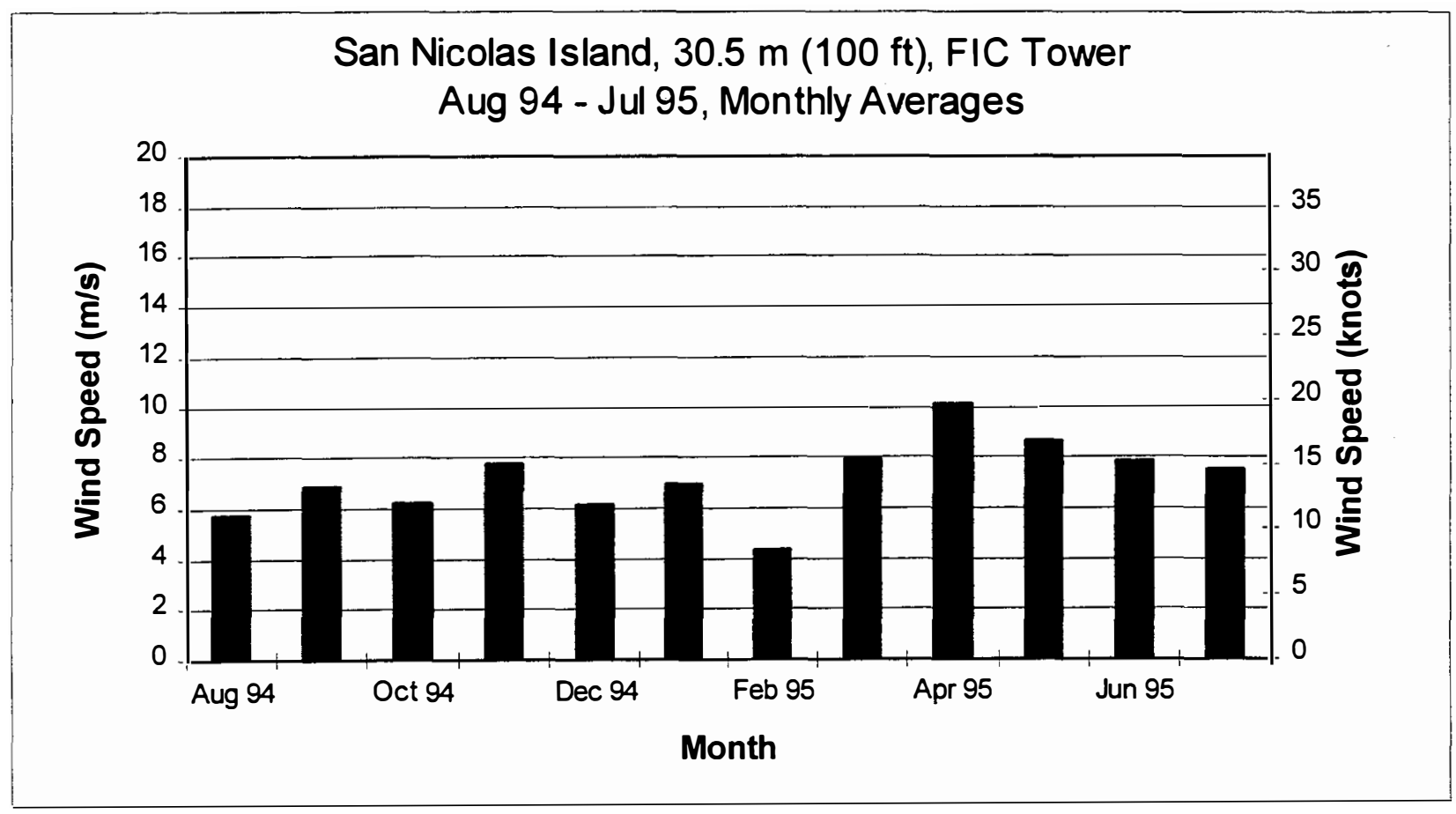

Figure 6: Annual Wind Speed Record 


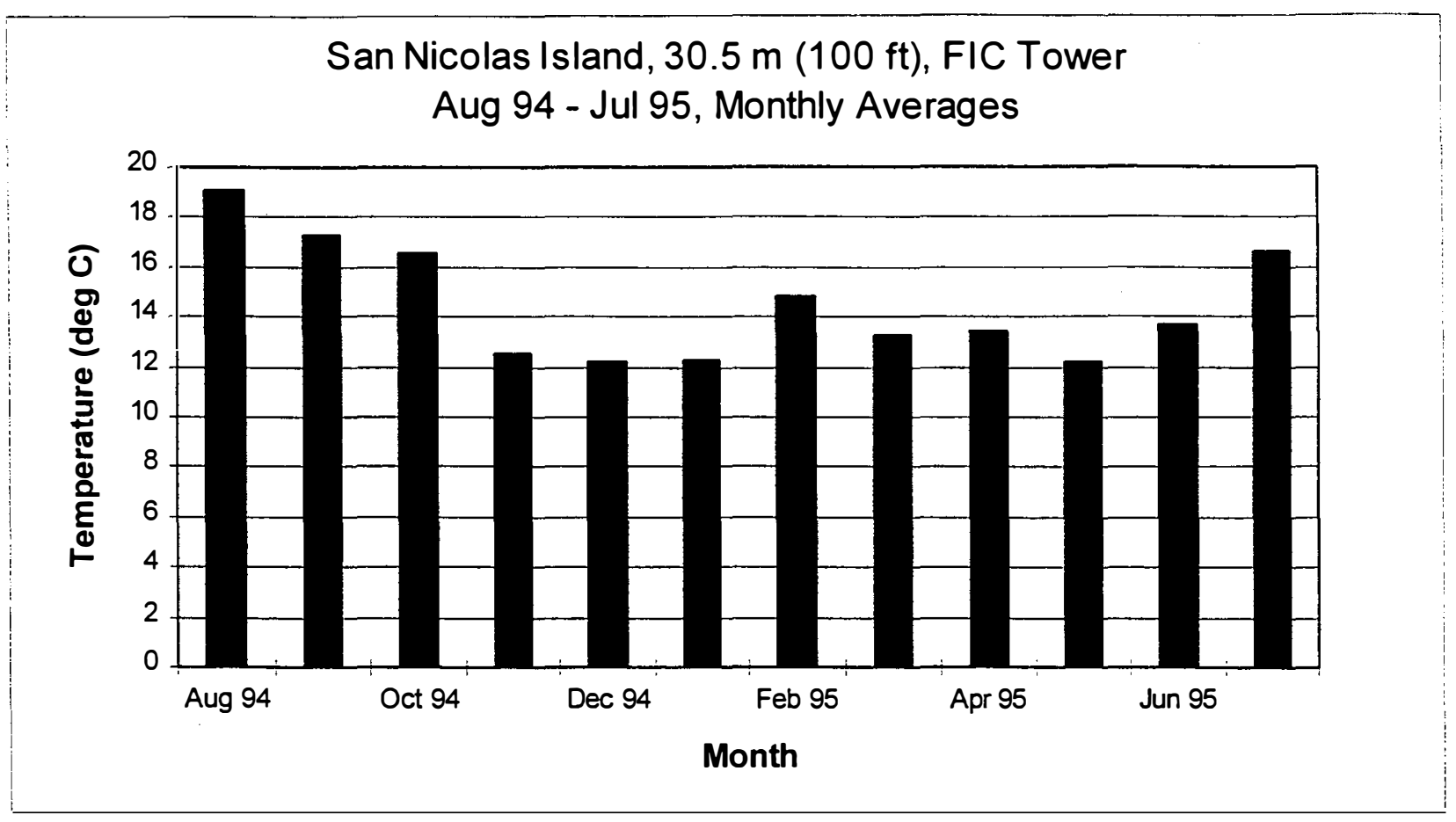

Figure 7: Annual Temperature Record

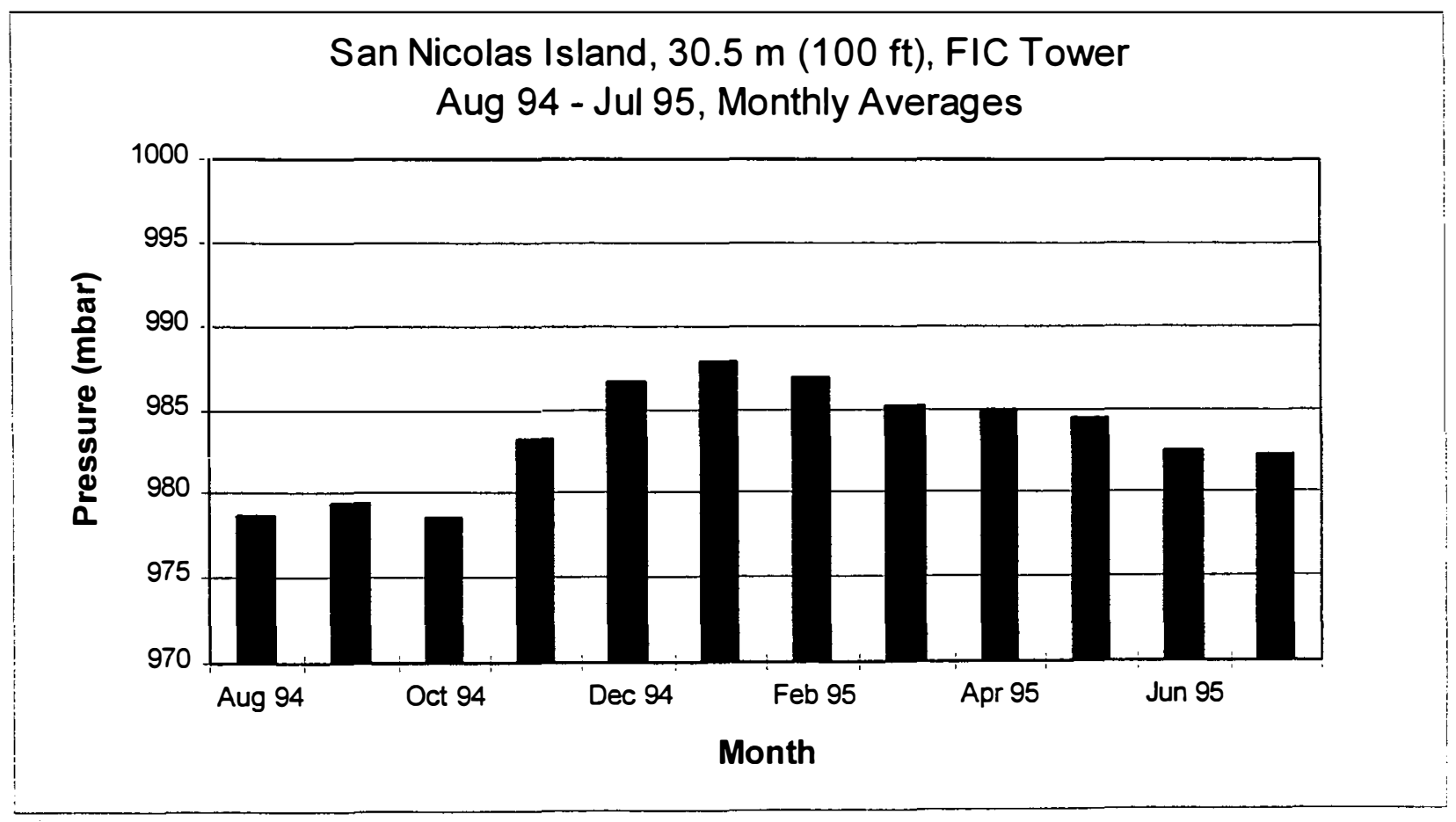

Figure 8: Annual Pressure Record 


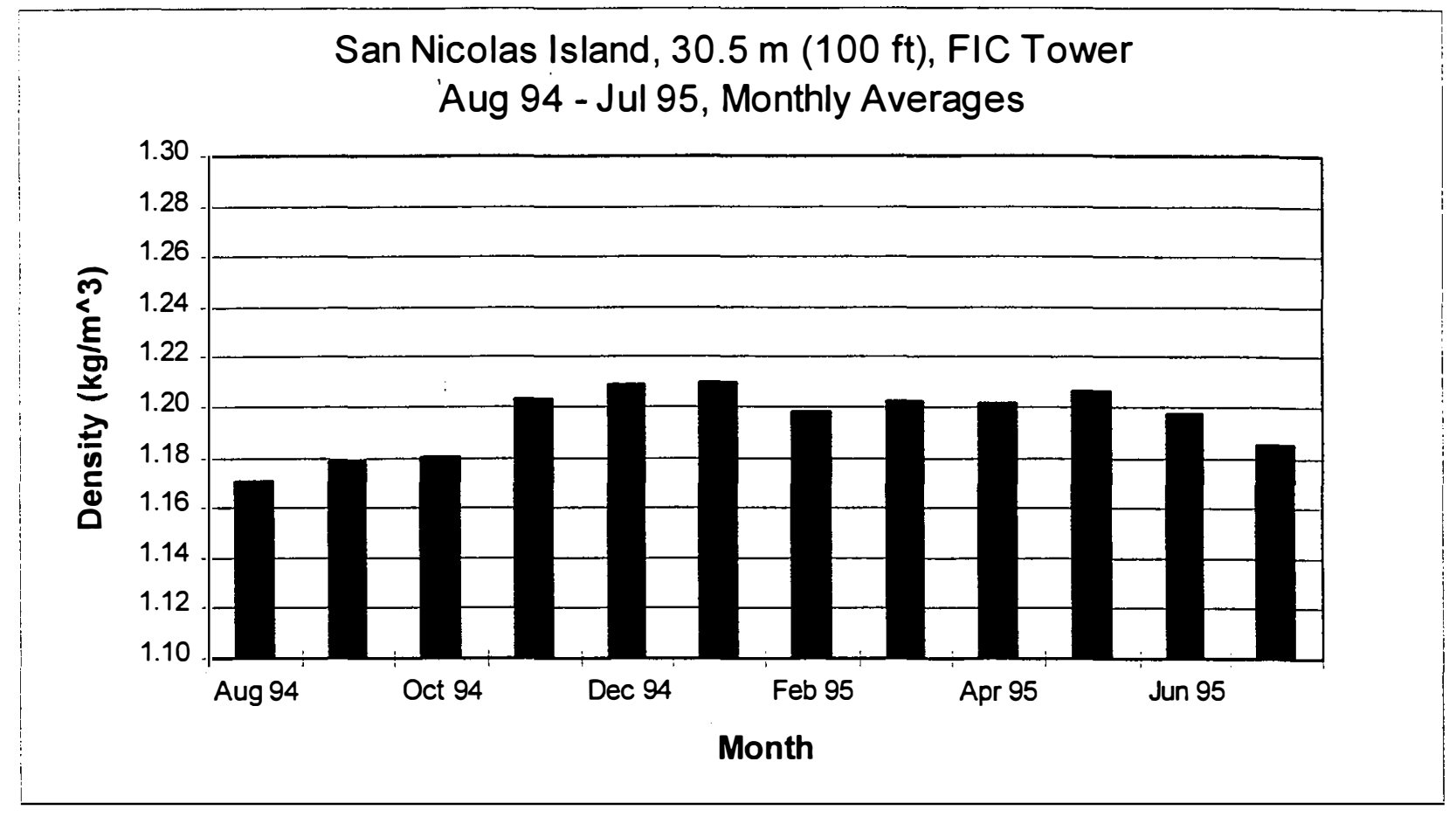

Figure 9: Annual Density Record

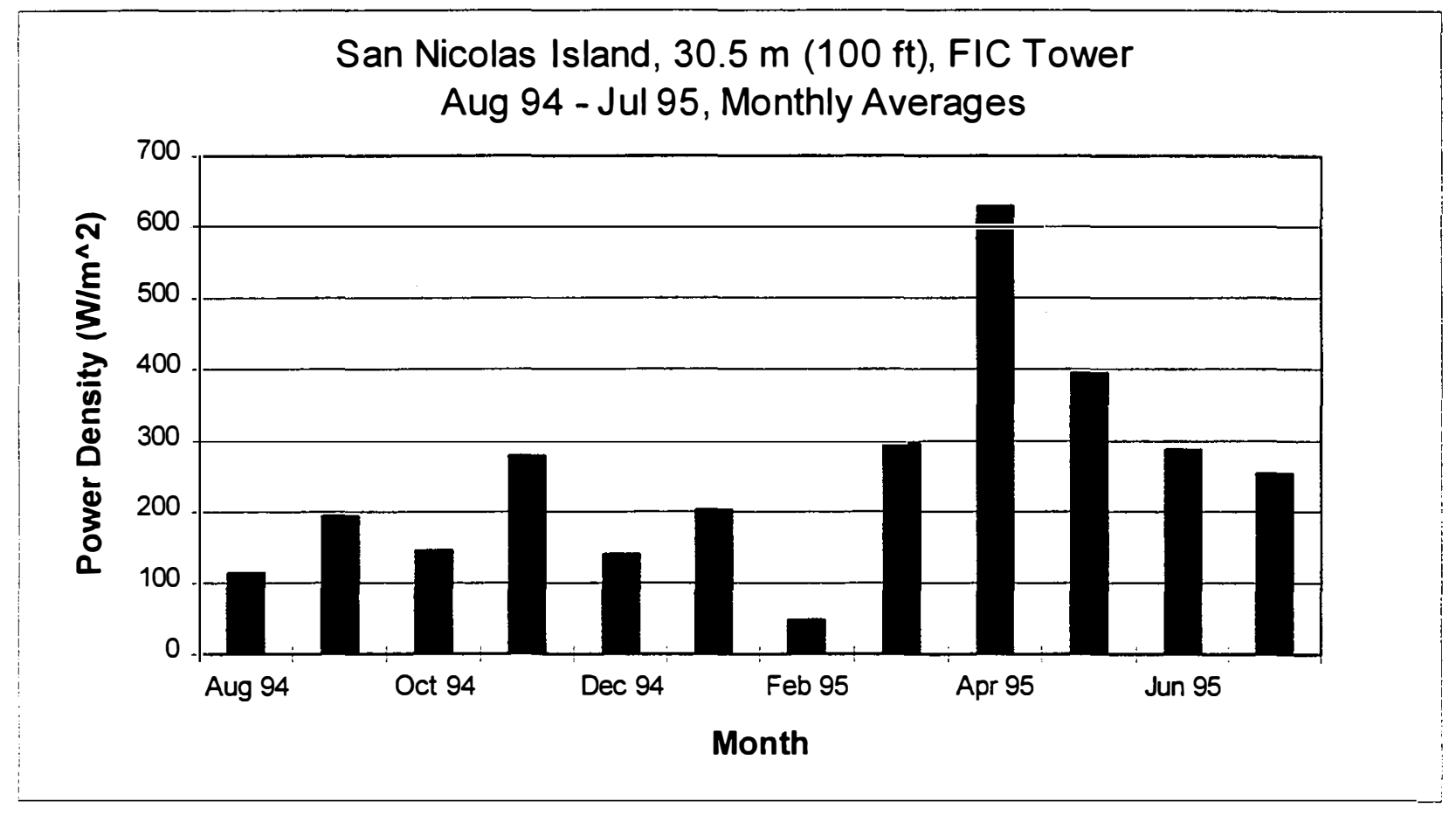

Figure 10: Annual Power Density Record 


\subsection{Annual Average Diurnal Wind Speed}

Although the diurnal (or daily cycle) wind speeds may vary widely from day to day, certain trends exist at most sites. These trends can be elucidated by averaging many daily cycles together. This is done by averaging the wind speeds for each hour of the day over the averaging period, in this case one year. For example, all wind speeds for 0000 to 0100 hours each day are averaged and labeled 0100 , all wind speeds for 0100 to 0200 hours are averaged and labeled 0200 , and so on. The annual average diumal wind speed, as shown in Figure 11, is based on the NREL test data at $30.5 \mathrm{~m}(100 \mathrm{ft})$ on SNI Facility No. 186 from 1 August 1994 through 31 July 1995. The diumal wind speed pattern shows a single cycle with a $6.1 \mathrm{~m} / \mathrm{s}$ ( $12 \mathrm{knots})$ average low at 1100 hours and an $8.6 \mathrm{~m} / \mathrm{s}$ (17 knots) high at 2000 hours.

The same techniques used to calculate annual average diurnal wind speed distribution were used to calculate monthly averages, using NREL/SNI data. The monthly average diumal wind speeds appear in Appendix C.

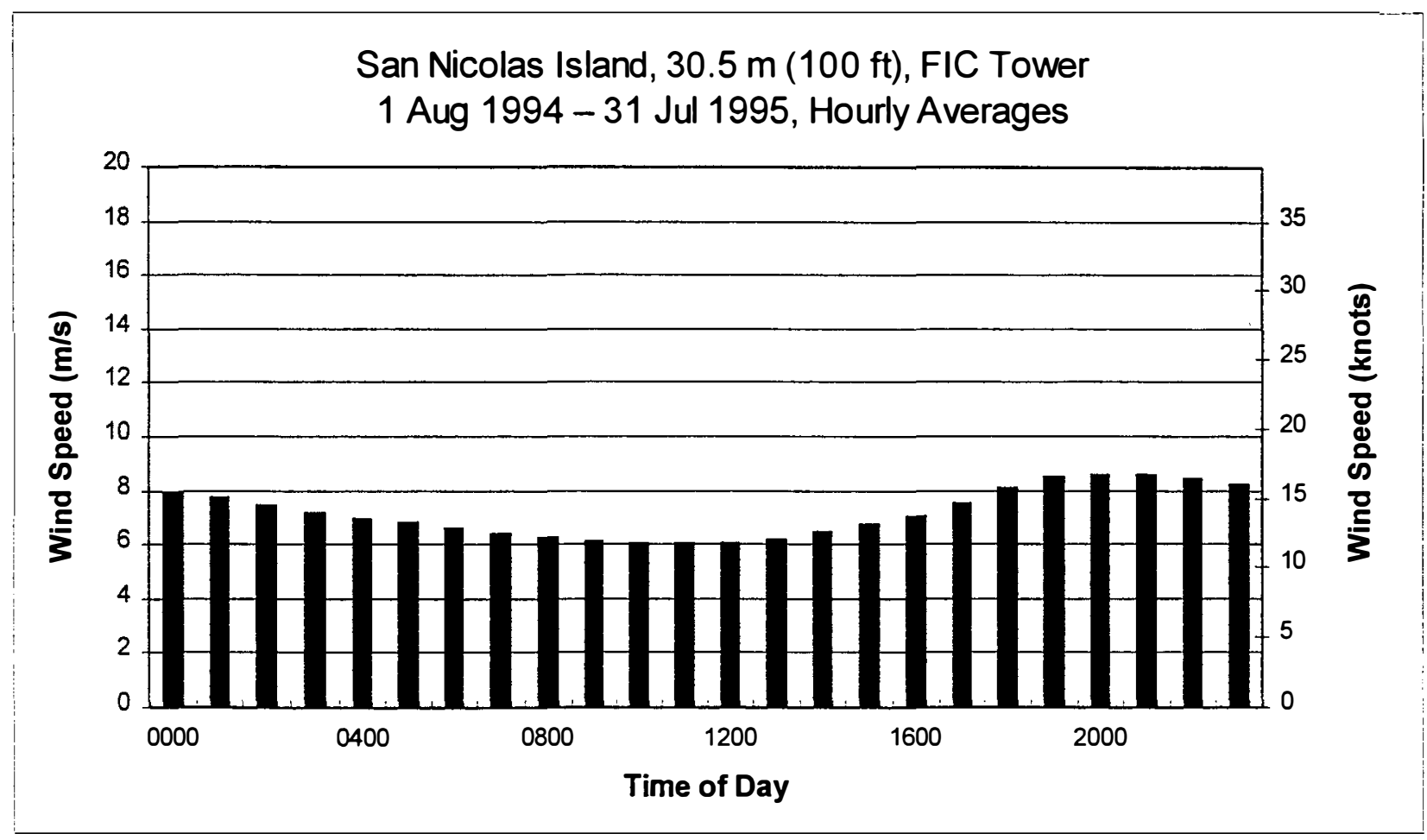

Figure 11: Annual Average Diurnal Wind Speed 


\subsection{Prevailing Wind Direction}

In this report "wind direction" refers to the source -- the direction from which the wind blows. Wind direction data is difficult to summarize because of the need to show both the duration of winds at different directions and the average wind speed at different directions, and these may not correlate well. As mentioned earlier, this data is presented three ways: percent time at each direction in Figure 12, average wind speed at each direction in Figure $13 \mathrm{a}$ and $\mathrm{b}$, and timeweighted average wind speed at each direction in Figure $14 \mathrm{a}$ and $\mathrm{b}$. The time-weighted averages will sound relatively low, since this calculation assigns a wind speed of zero for time not at the given direction. However, the sum of these values equals the annual average wind speed (from all directions). The percent-time and time-weighted-average plots both show the primary wind direction out of the northwest to north by northwest, with occasional wind from the west and southwest. (Note: Figures 13a and 14a have the units $\mathrm{m} / \mathrm{s}$; figures $13 \mathrm{~b}$ and $14 \mathrm{~b}$ are in knots.)

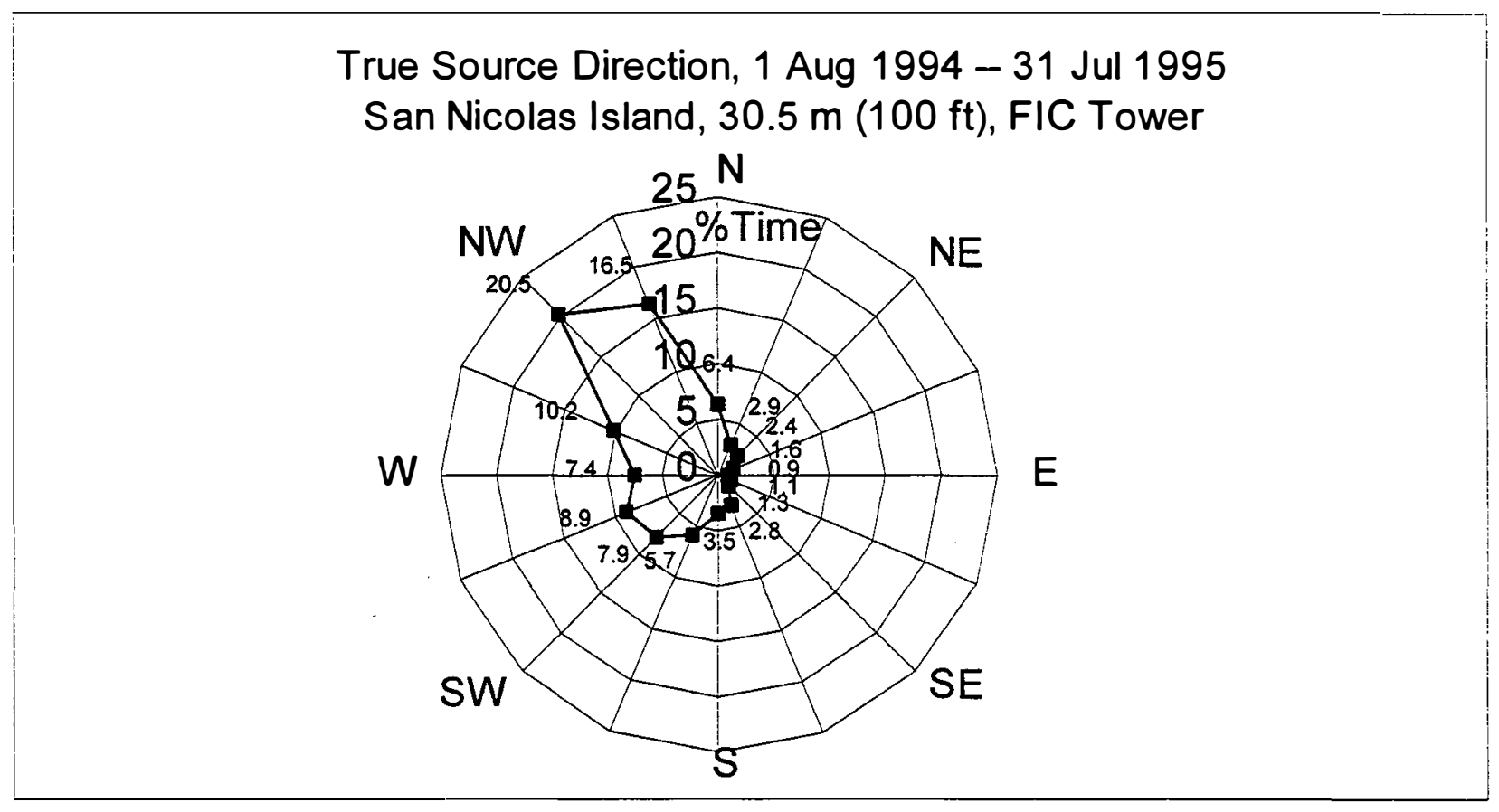

Figure 12: Wind Rose: Percent Time 
True Source Direction, 1 Aug 1994 - 31 Jul 1995 San Nicolas Island, $30.5 \mathrm{~m}$ (100 ft), FIC Tower

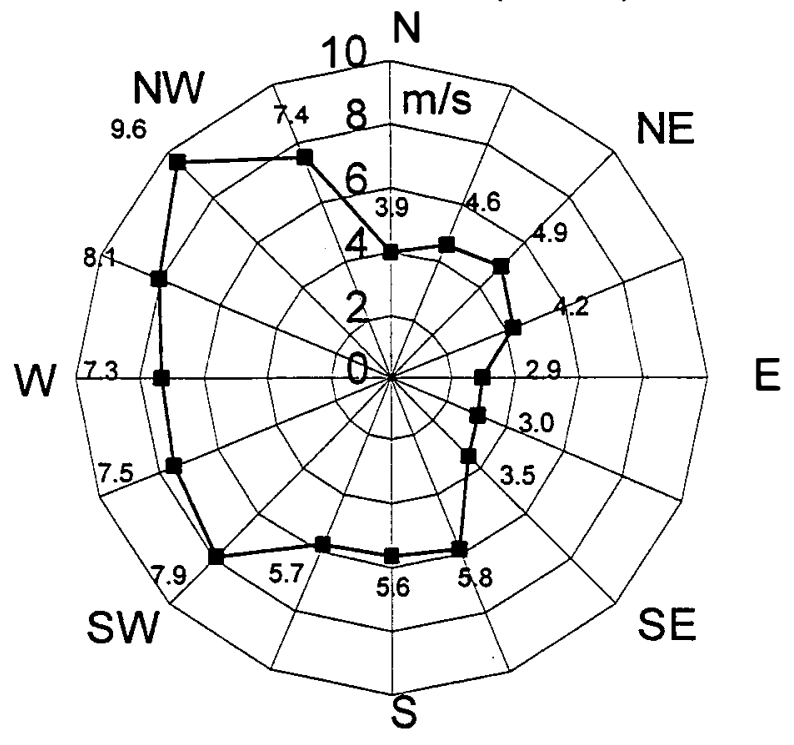

Figure 13a: Wind Rose: Average Wind Speed (m/s)

True Source Direction, 1 Aug 1994 - 31 Jul 1995

San Nicolas Island, $30.5 \mathrm{~m}$ (100 ft), FIC Tower

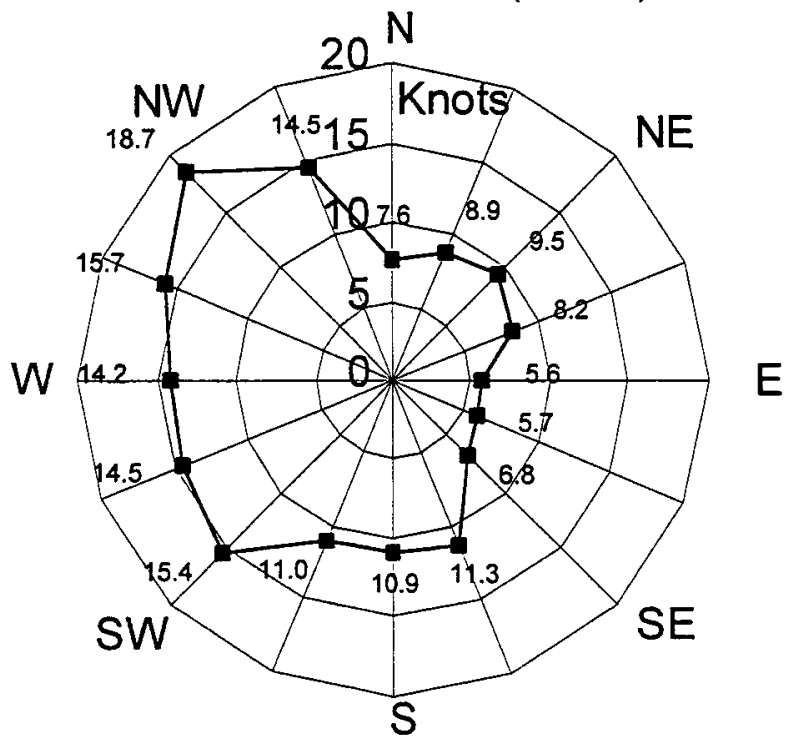

Figure 13b: Wind Rose: Average Wind Speed (knots) 
True Source Direction, 1 Aug 1994 - 31 Jul 1995

San Nicolas Island, $30.5 \mathrm{~m}$ (100 ft), FIC Tower

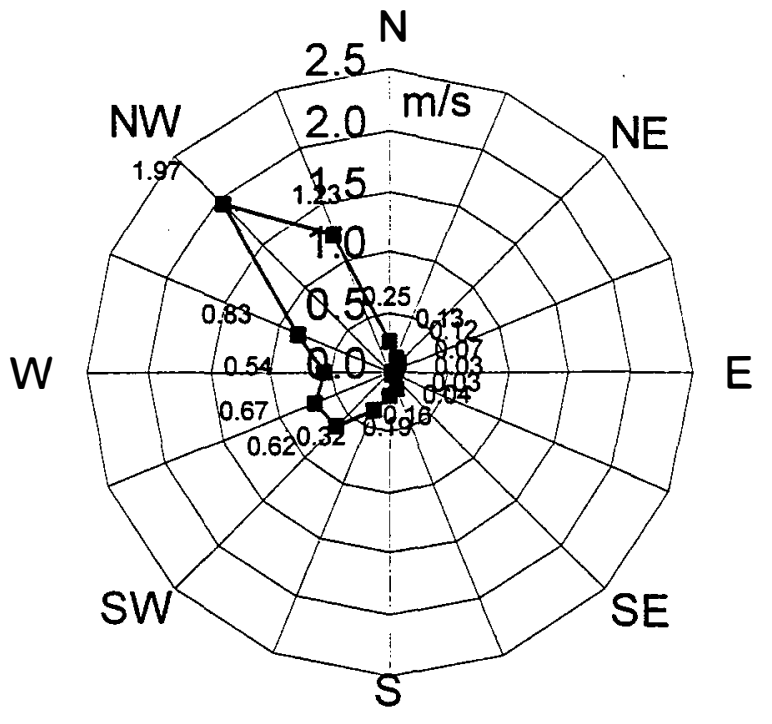

Figure 14a: Wind Rose: Time Weighted Average Wind Speed (m/s)

True Source Direction, 1 Aug 1994 - 31 Jul 1995

San Nicolas Island, $30.5 \mathrm{~m}$ (100 ft), FIC Tower

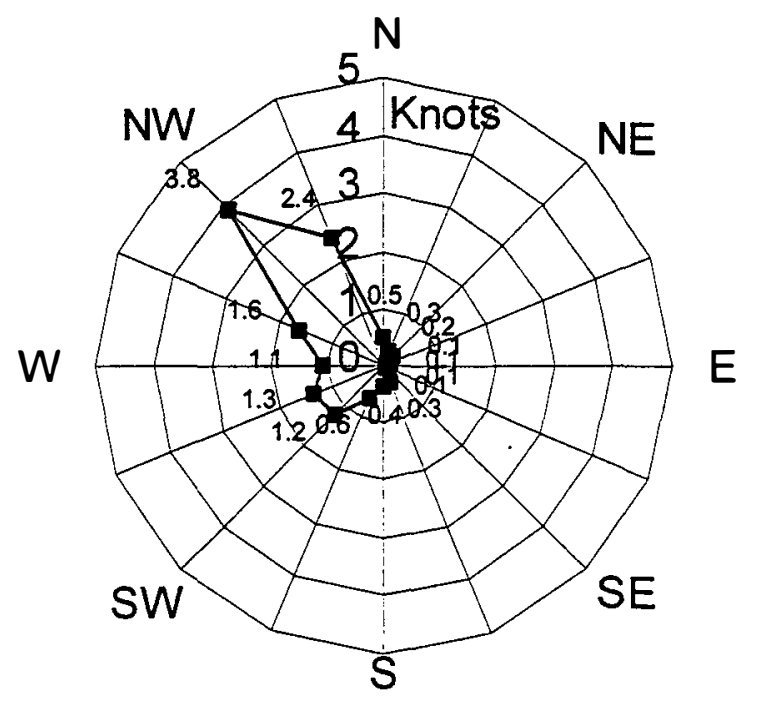

Figure 14b: Wind Rose: Time Weighted Average Wind Speed (knots) 


\subsection{CONCLUSION}

The predominantly northwest direction of the wind would favor that end of the island for wind generation, but facility operations confine any potential windfarm to the central region which was tested for this study. San Nicolas Island has an excellent wind resource at that central site, with an annual average wind speed of $7.2 \mathrm{~m} / \mathrm{s}$ (14.0 knots) as measured by NREL at $30.5 \mathrm{~m}$ (100 $\mathrm{ft}$ ) at Facility No. 186 during the year ending July 31, 1995. The 32-year historical data set shows an average wind speed of $6.1 \mathrm{~m} / \mathrm{s}$ (11.8 knots), with a standard deviation on the annual averages of $0.6 \mathrm{~m} / \mathrm{s}(1.2 \mathrm{knots})$. This also would indicate a good site, with annual averages falling between $4.3 \mathrm{~m} / \mathrm{s}$ ( $8.4 \mathrm{knots})$ and $7.9 \mathrm{~m} / \mathrm{s}$ (15.3 knots). Although the historical data carries a statistical advantage in its duration, the NREL data had much higher quality control.

The annual wind speed pattern varied from a low of $4.5 \mathrm{~m} / \mathrm{s}(8.7 \mathrm{knots})$ in February to a high of $10.3 \mathrm{~m} / \mathrm{s}$ ( $20 \mathrm{knots})$ in April, based on one month averages. The diumal cycle swung from 6.1 $\mathrm{m} / \mathrm{s}$ (12 knots) at 1100 hours to $8.6 \mathrm{~m} / \mathrm{s}$ (17 knots) at 2000 hours. The mild effect of these cycles imply a fairly steady wind resource, which is favorable for supplemental wind energy. However, short term wind speed variations are significant, as indicated by the standard deviation of $4.8 \mathrm{~m} / \mathrm{s}$ ( $9.3 \mathrm{knots})$ and extremes of $0 \mathrm{~m} / \mathrm{s}$ ( 0 knots) and $28.5 \mathrm{~m} / \mathrm{s}$ ( $55.4 \mathrm{knots})$. Such variations could place significant demands on a hybrid wind/diesel energy system design. 


\section{REFERENCES}

1. Dulka, K. et al. (1993). San Nicolas Island and Santa Cruz Island Site Manual, Naval Air Weapons Center Weapons Division.

2. Taylor, J. (1988). Fundamentals of Measurement Error, Neff Instrument Corporation.

3. American Society of Mechanical Engineers. (1986) Instruments and Apparatus, Part 1: Measurement Uncertainty, ANSI/ASME PTC 19.1-1985.

4. Elliott, D. L. et al. (1987). Wind Energy Resource Atlas of the United States, DOE/CH10093-4, Pacific Northwest Laboratory.

5. Pal, D.; Smuck, S. (1988). Wind Power Assessment for Offshore Landing Field, San Nicolas Island, CA, TM no 74-88-06, Naval Civil Engineering Laboratory.

6. McKenna, E. (1993). Report on the Visit to DOD - USN Facilities for SERDP Project, Inter-Office Memorandum, National Renewable Energy Laboratory.

7. Taylor, W. H., Jr.; Pal, D. (1981) Preliminary Wind Resource Assessment for Naval Shore Establishments, TM no M-63-81-20.

8. Reed, J. (1979). Some Variability Statistics of Available Wind Power, SAND 78-1735, Sandia National Laboratories.

9. Reed, J. (1979). Wind Power Climatology of the United States - Supplement, SAND 781620, Sandia National Laboratories.

10. Reed, J. (1978). Wind Speed Distribution Changes With Height at Selected Weather Stations, SAND 76-0714, Sandia National Laboratories. 
APPENDIX A: Daily Wind Speed Records 

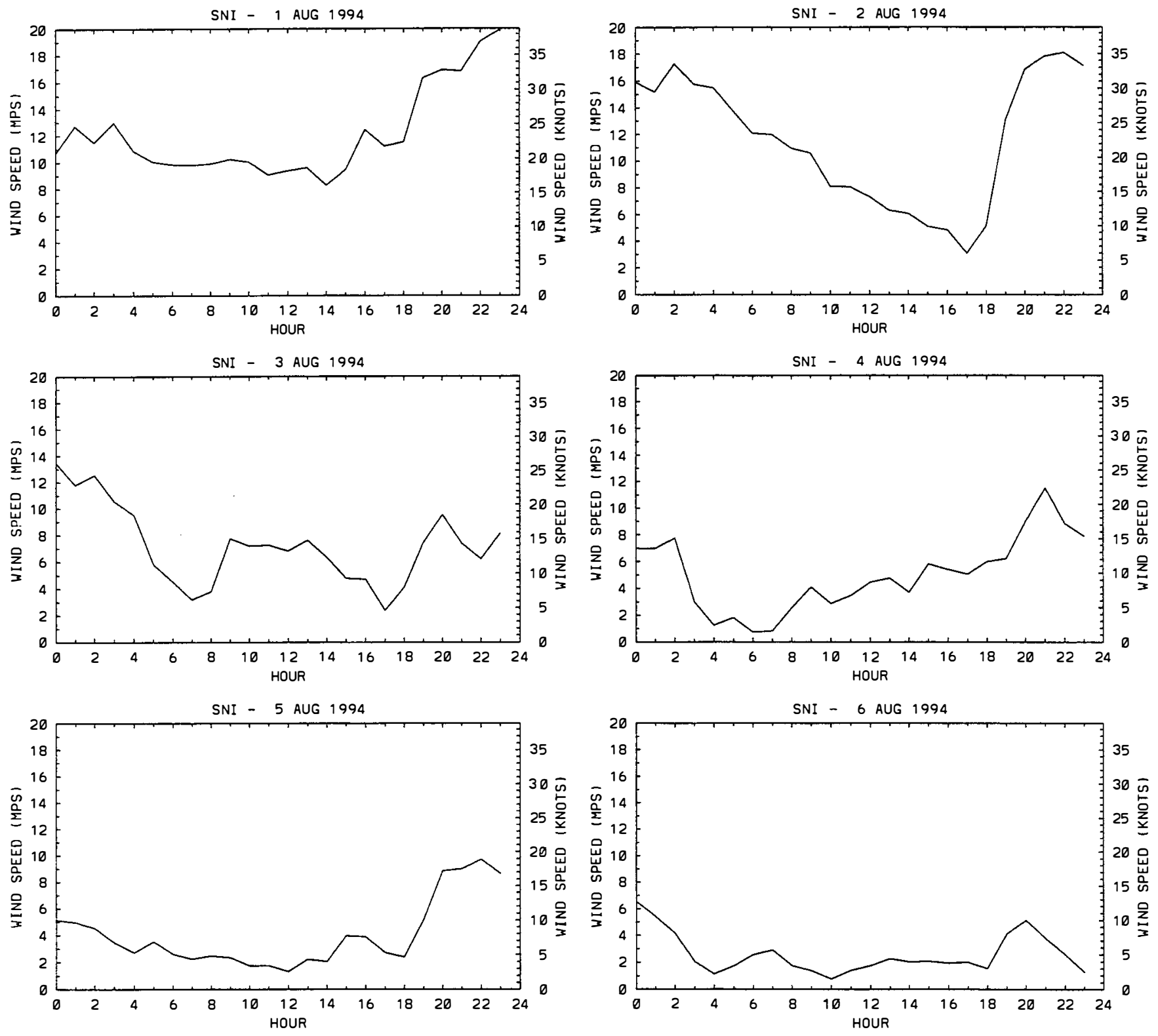

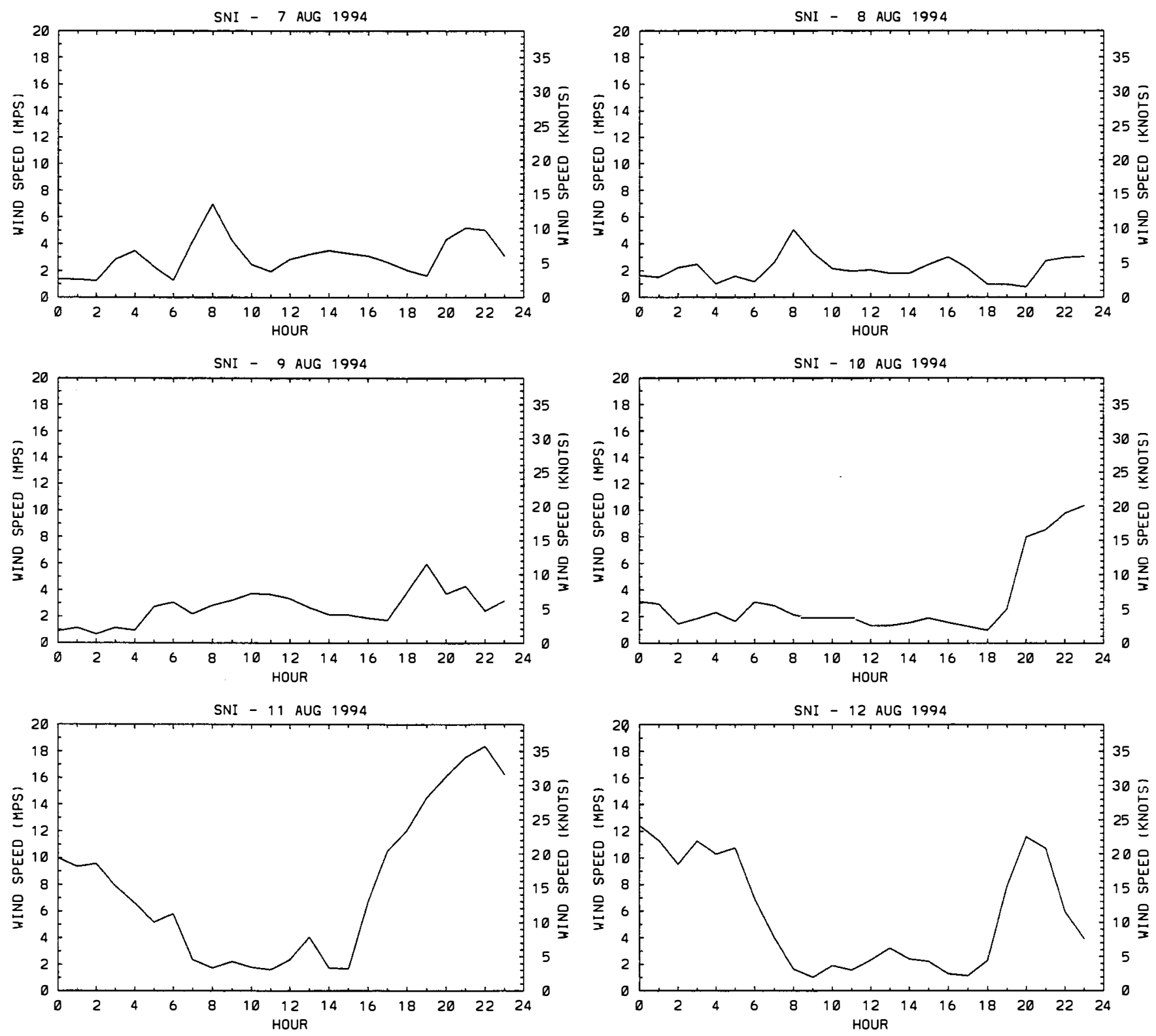

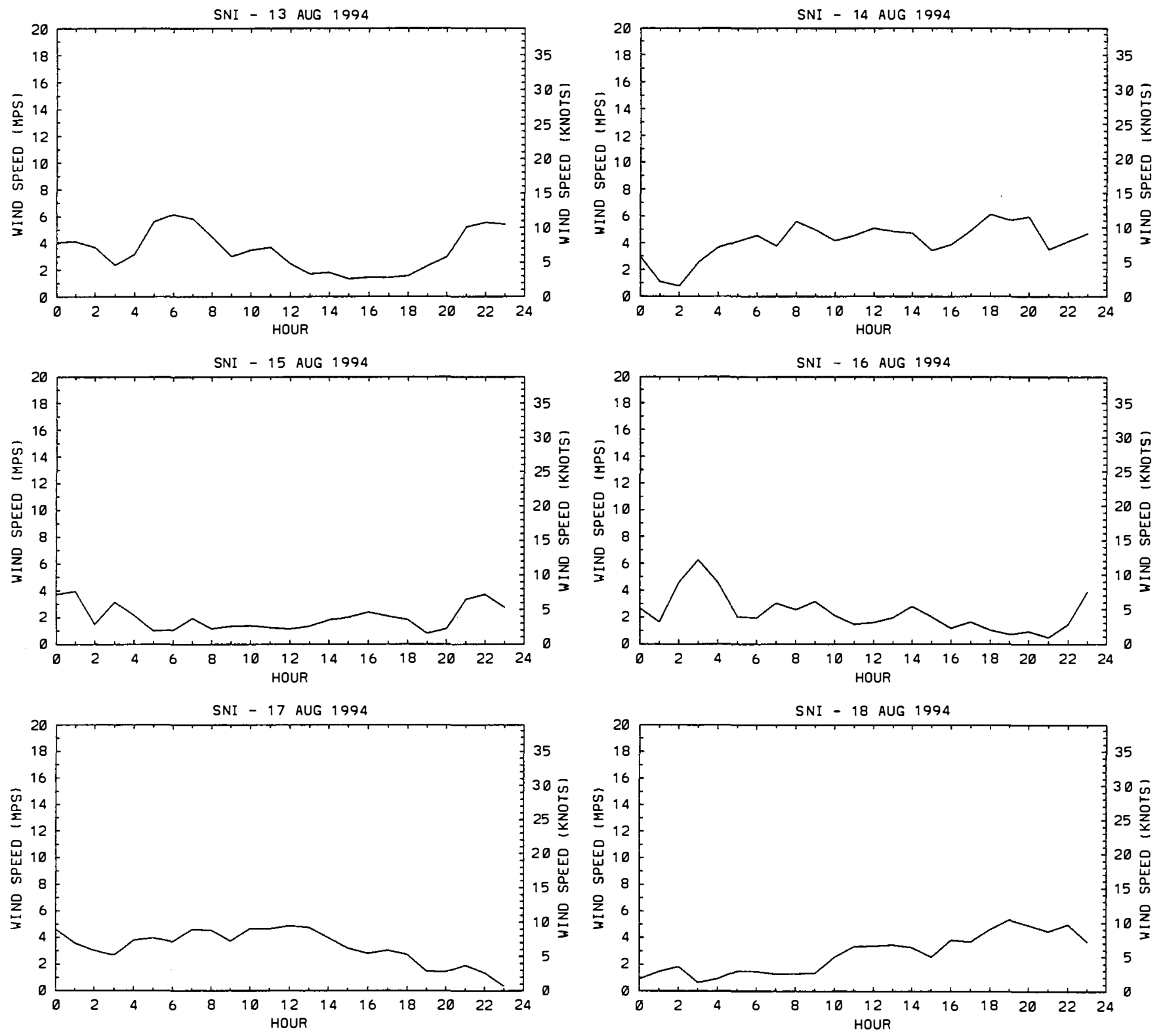

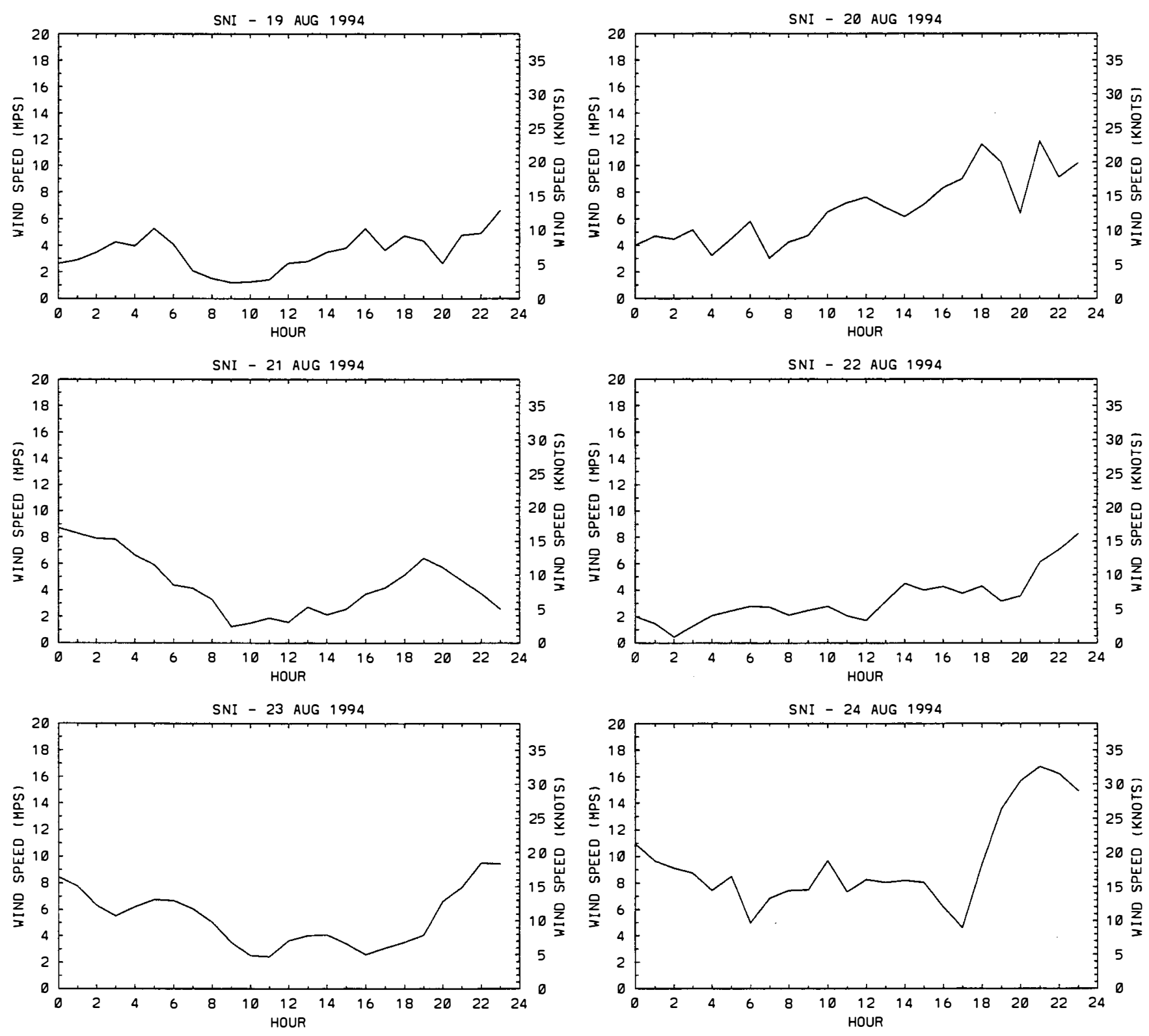

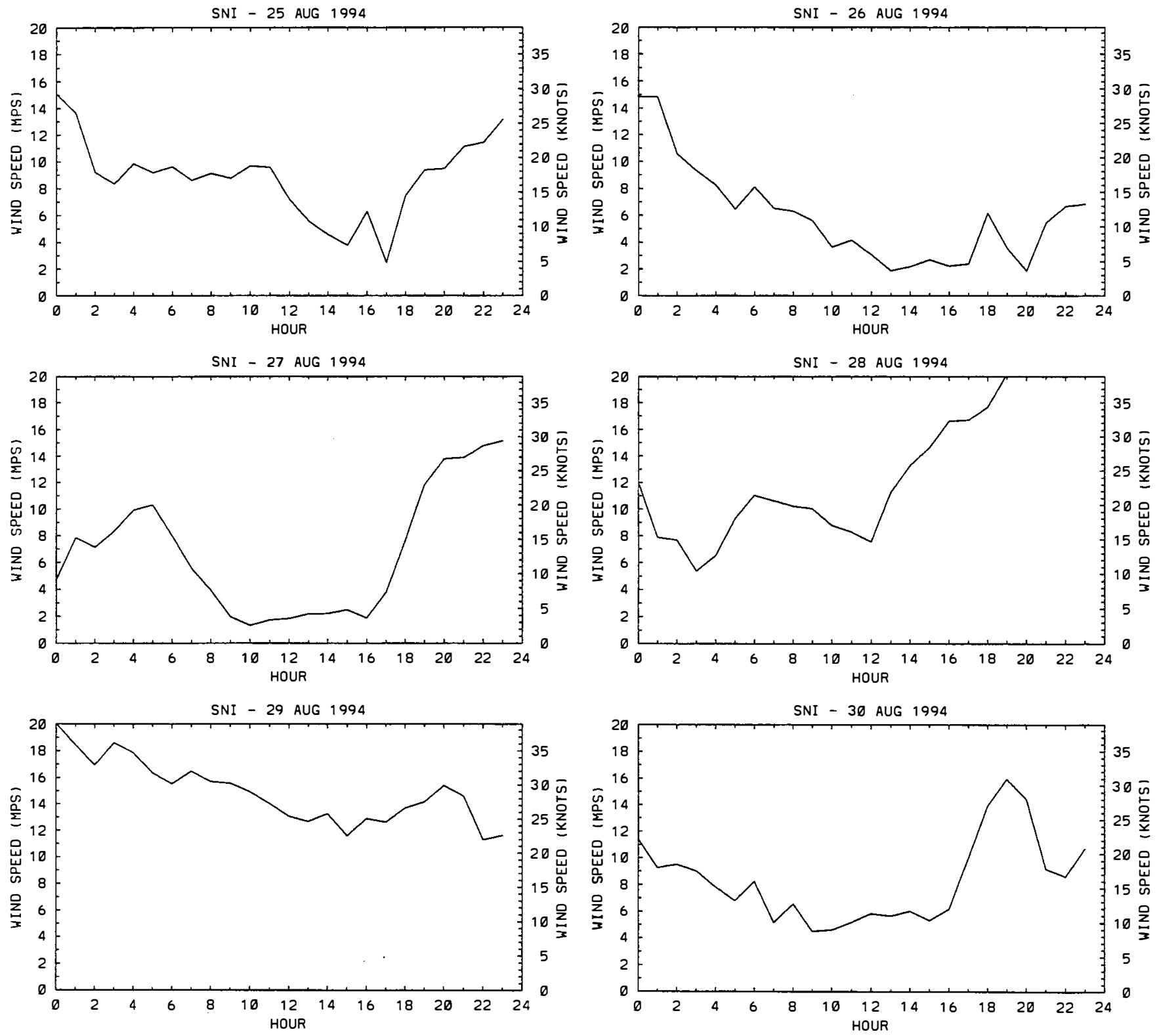

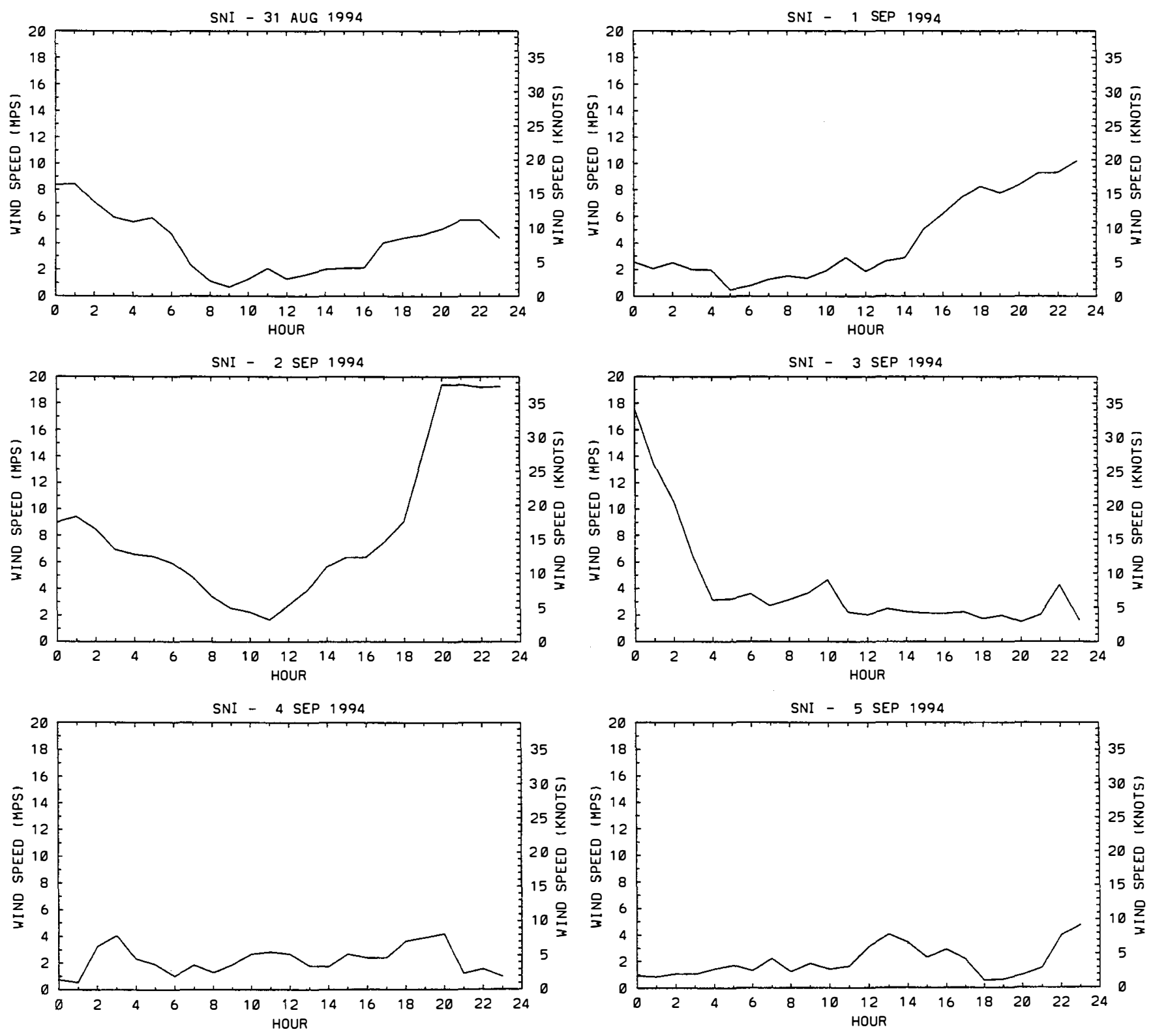

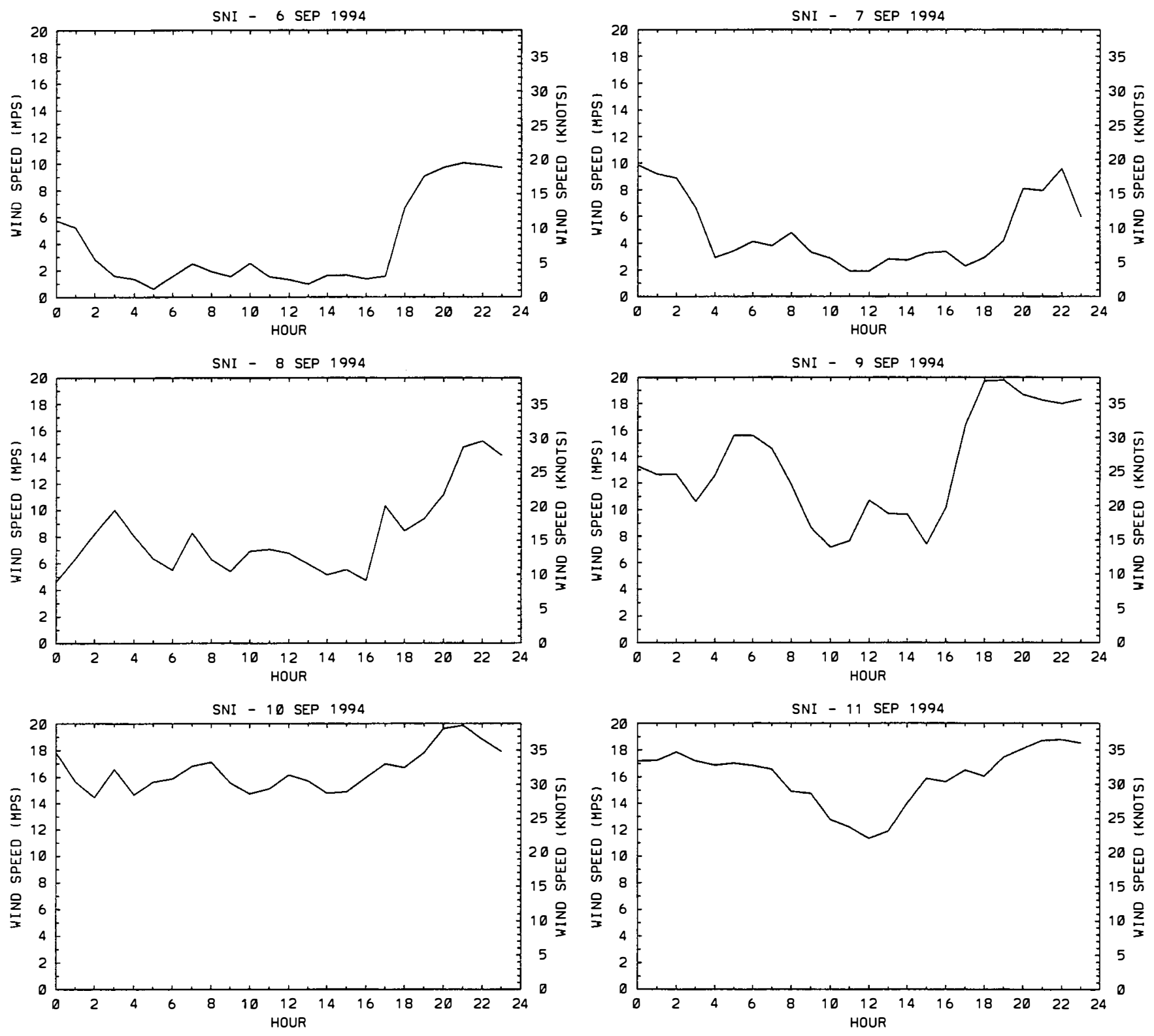

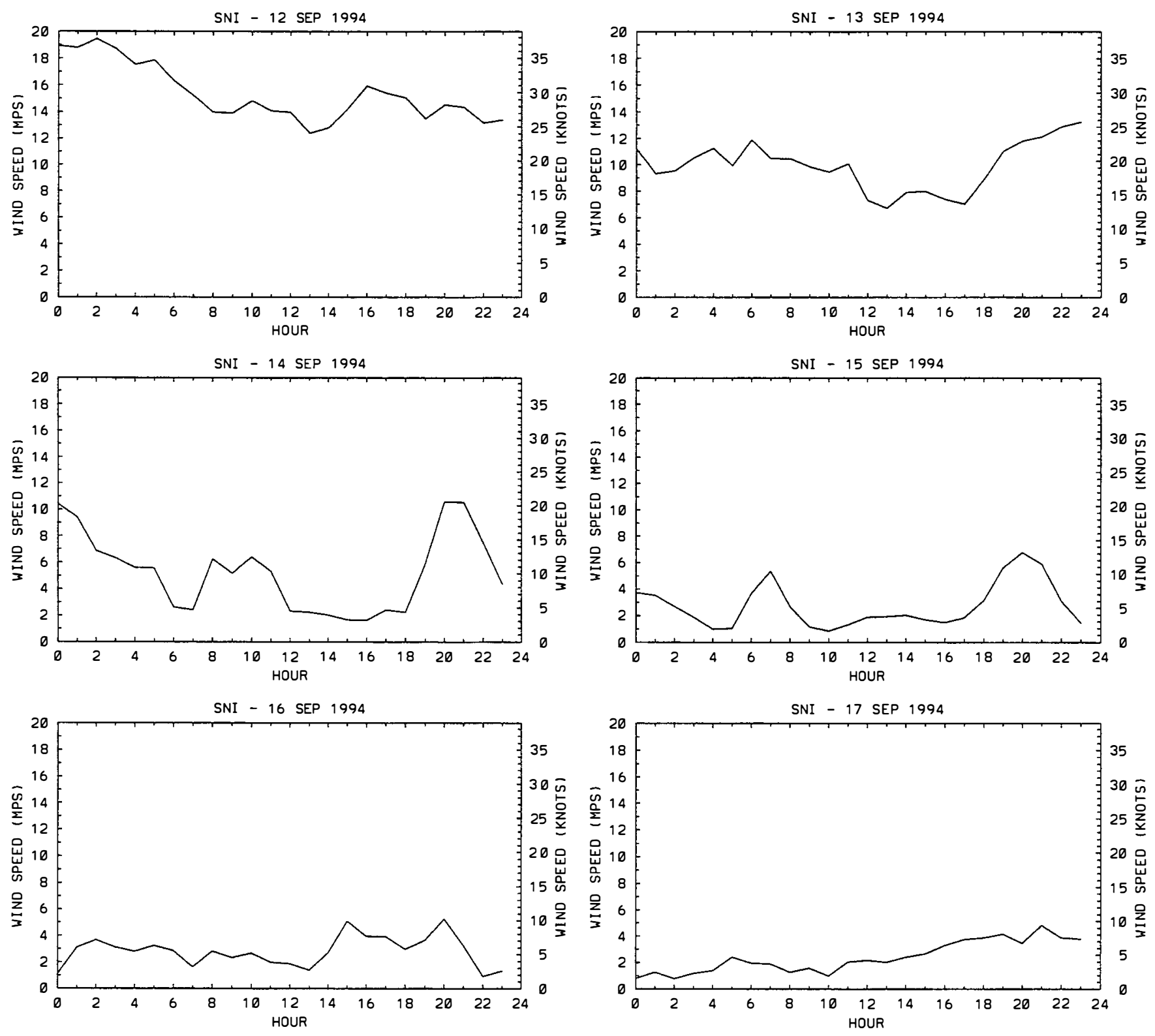

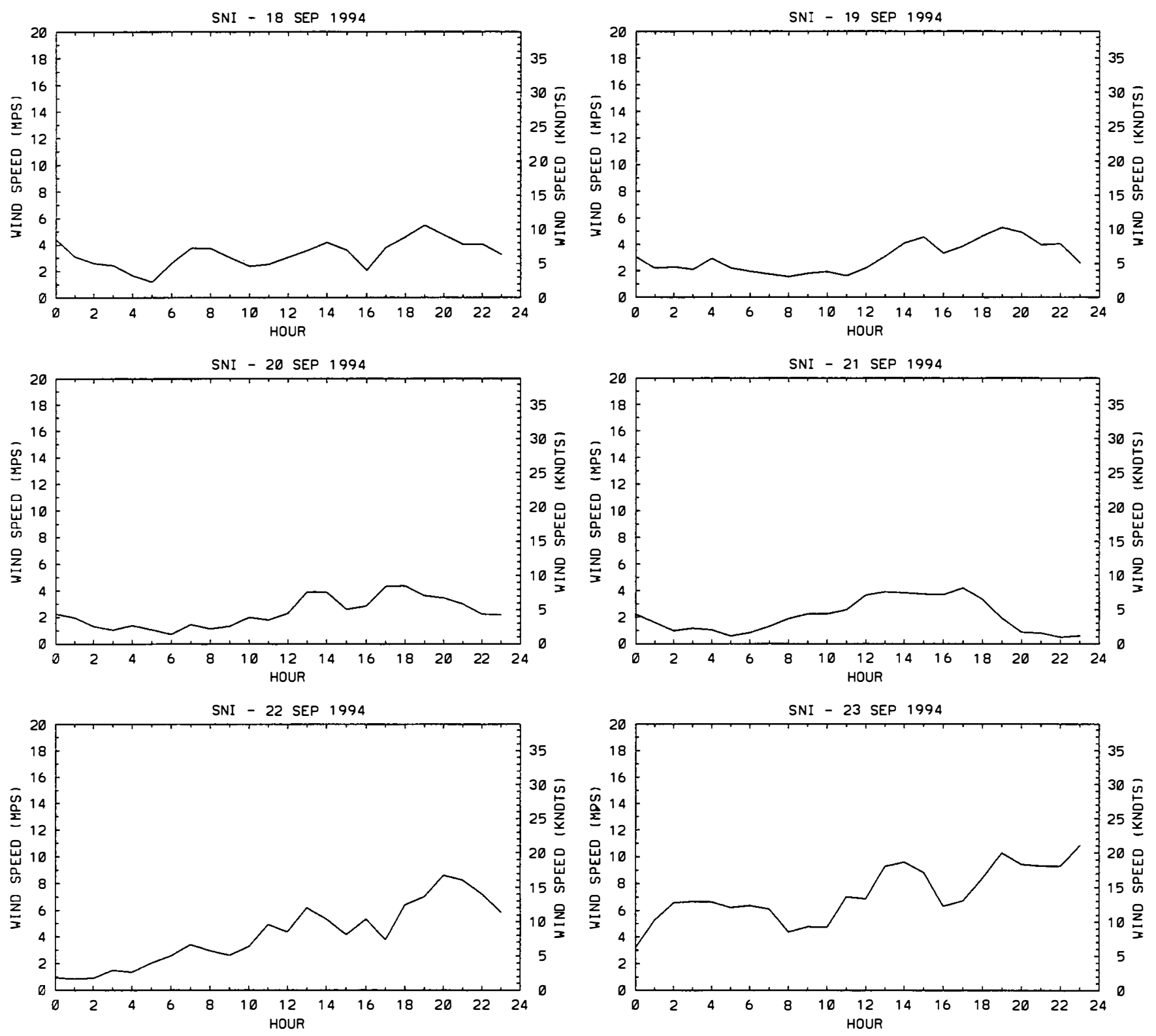

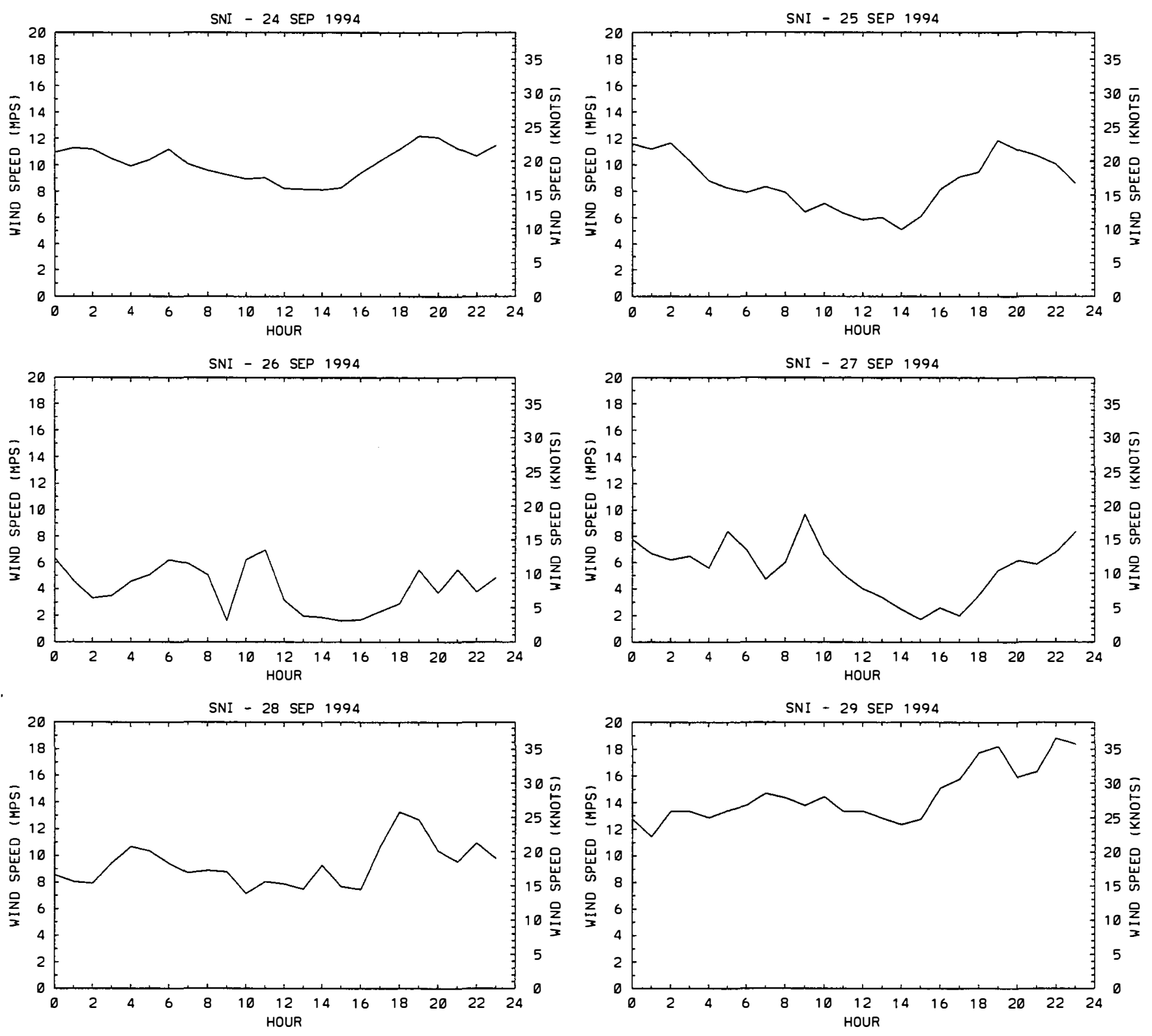

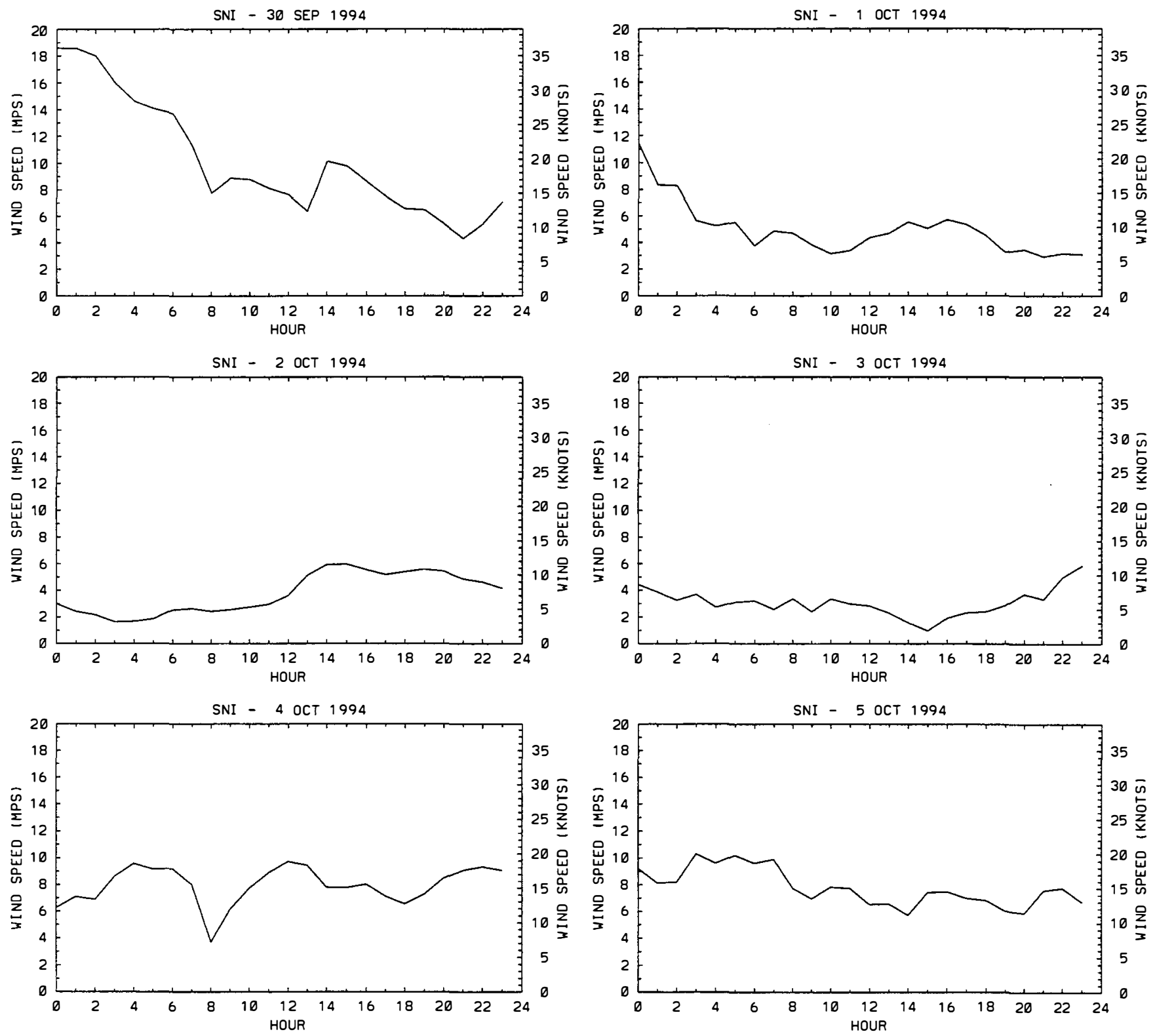

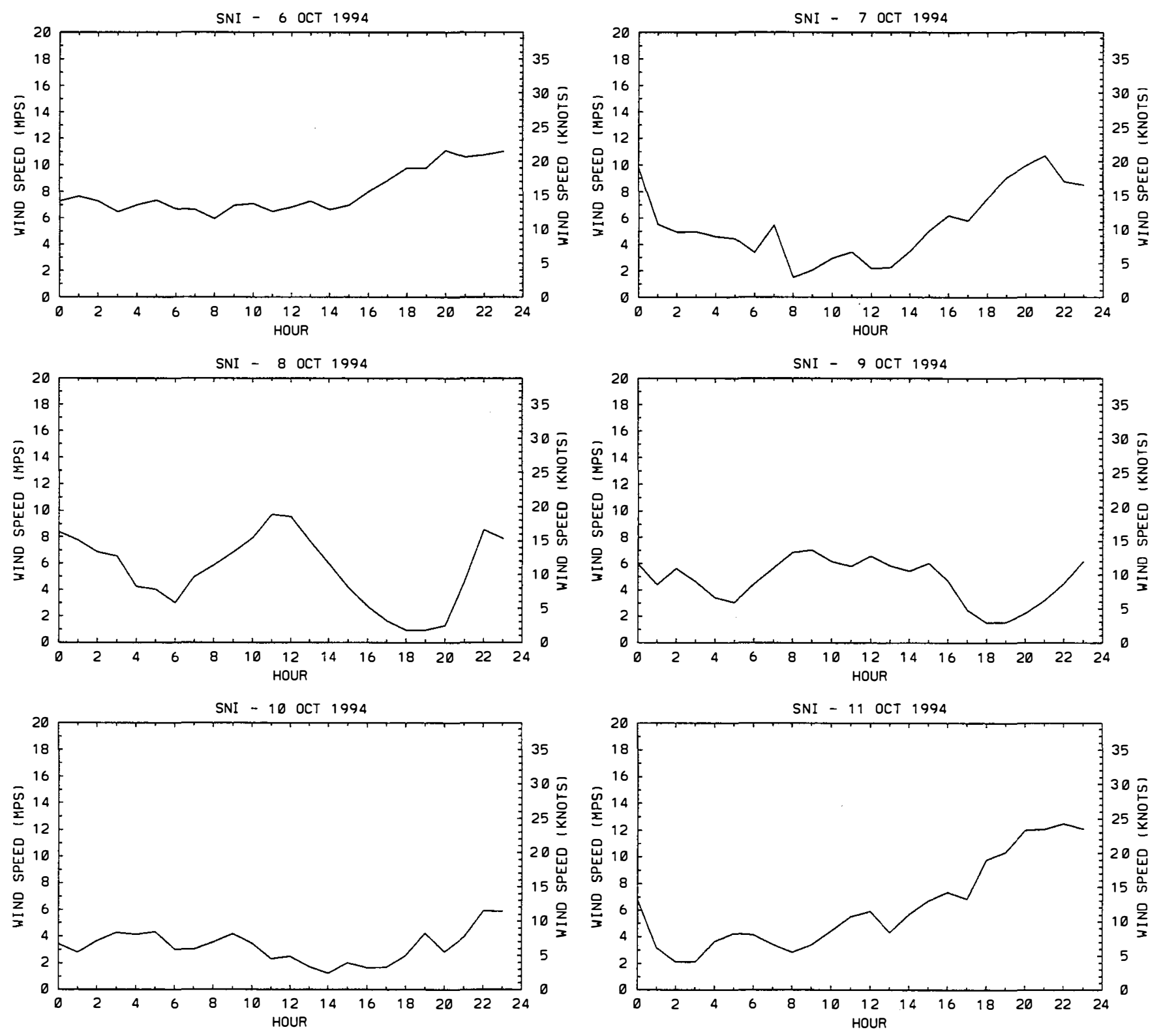

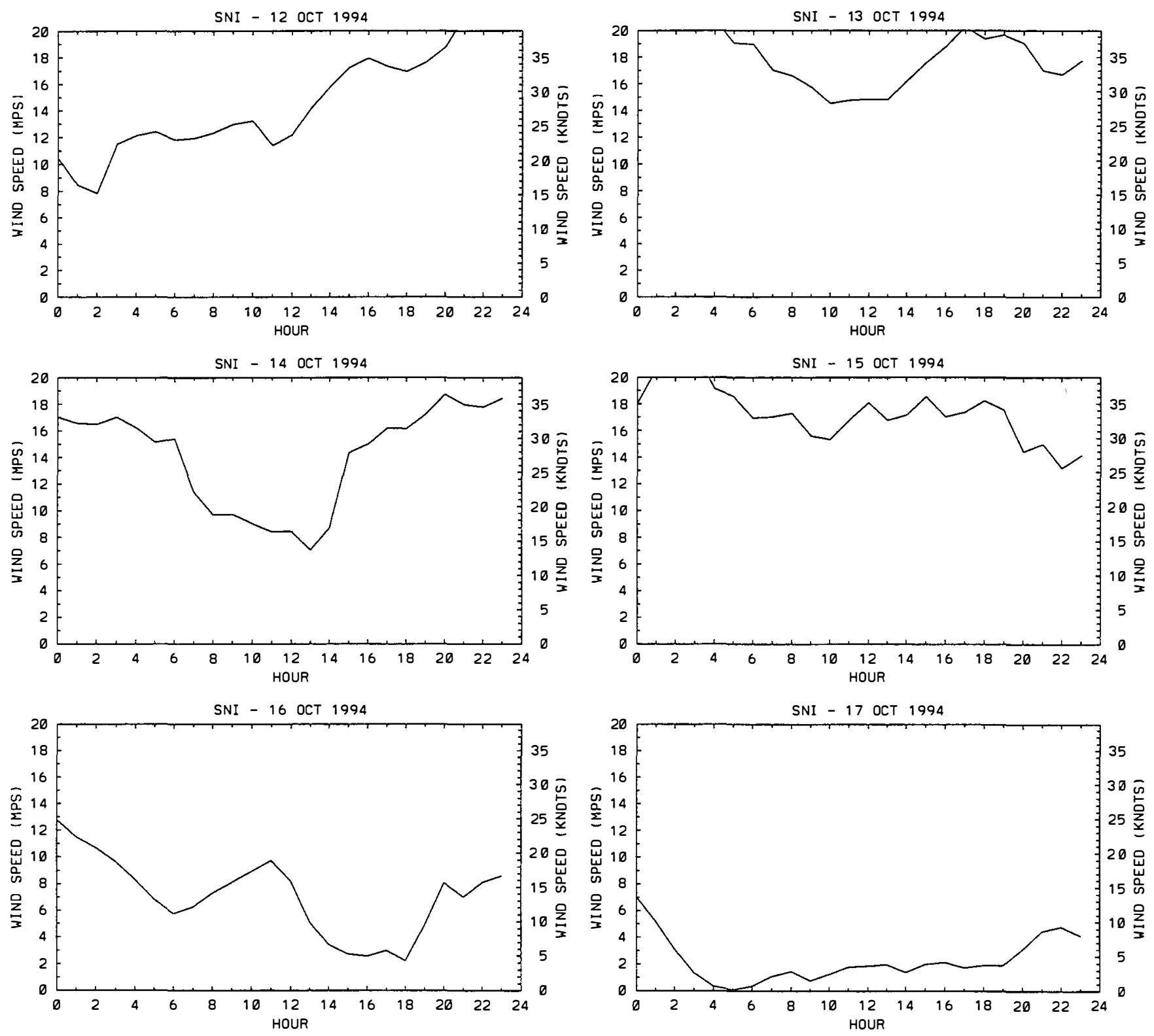

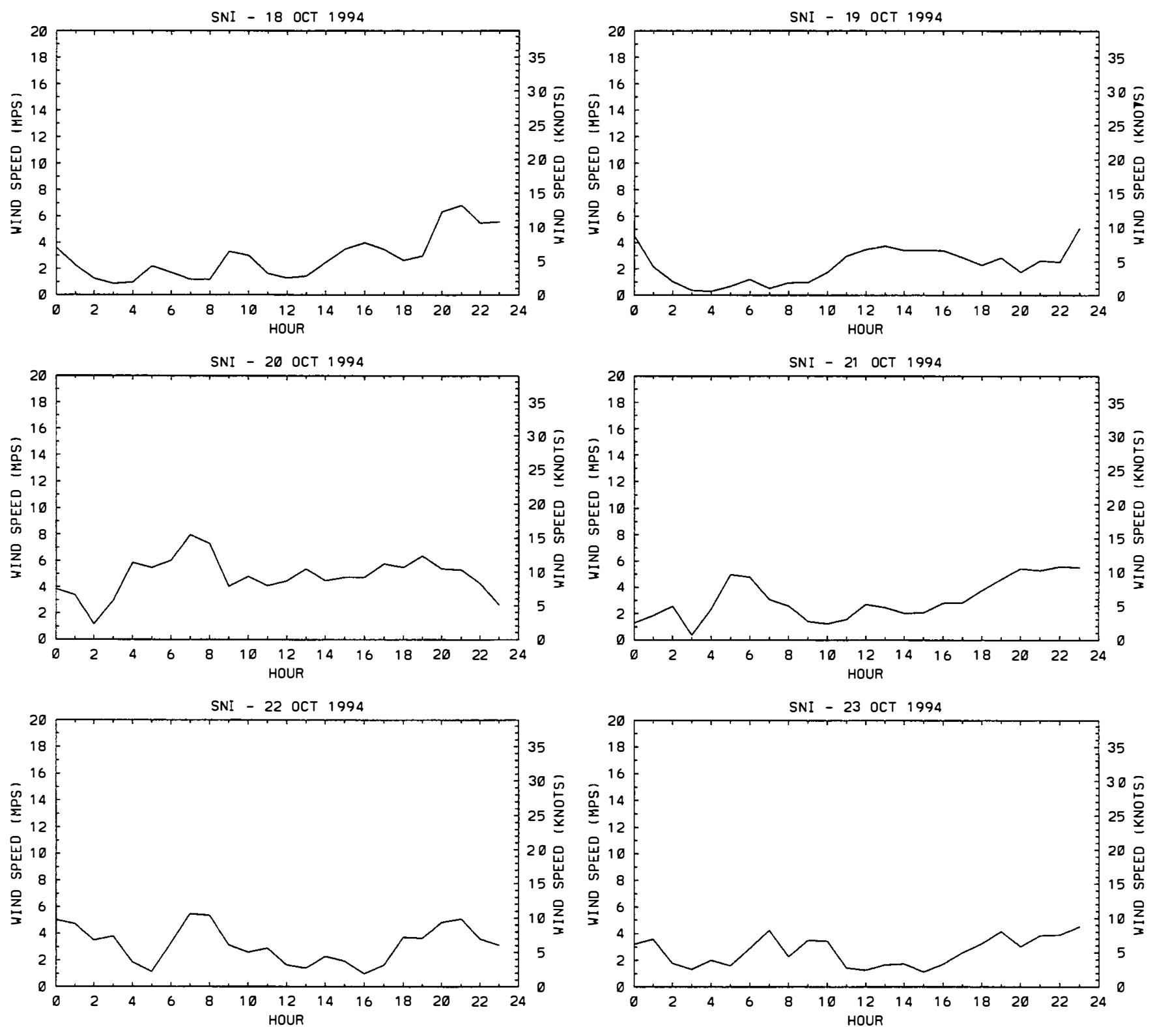

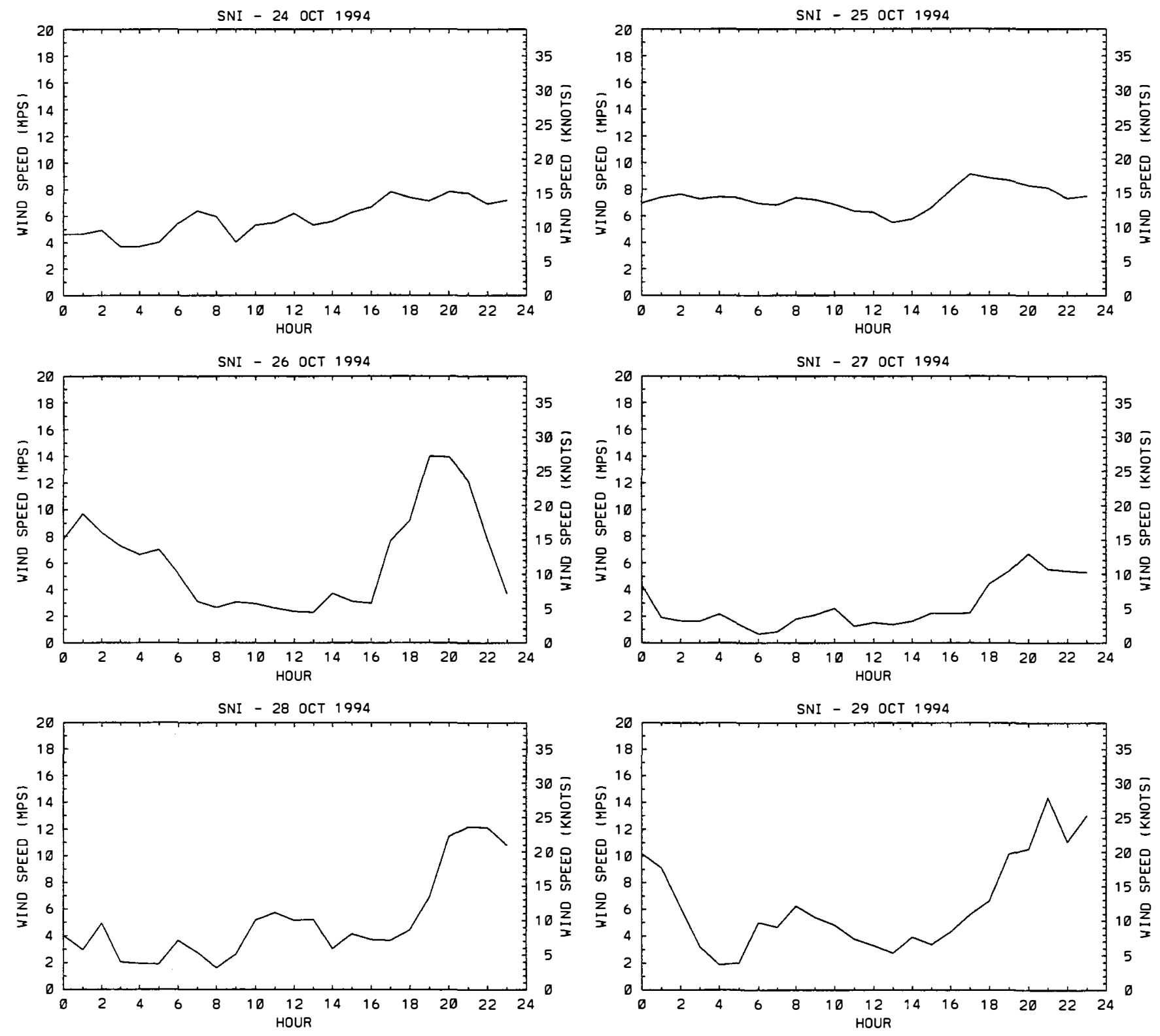

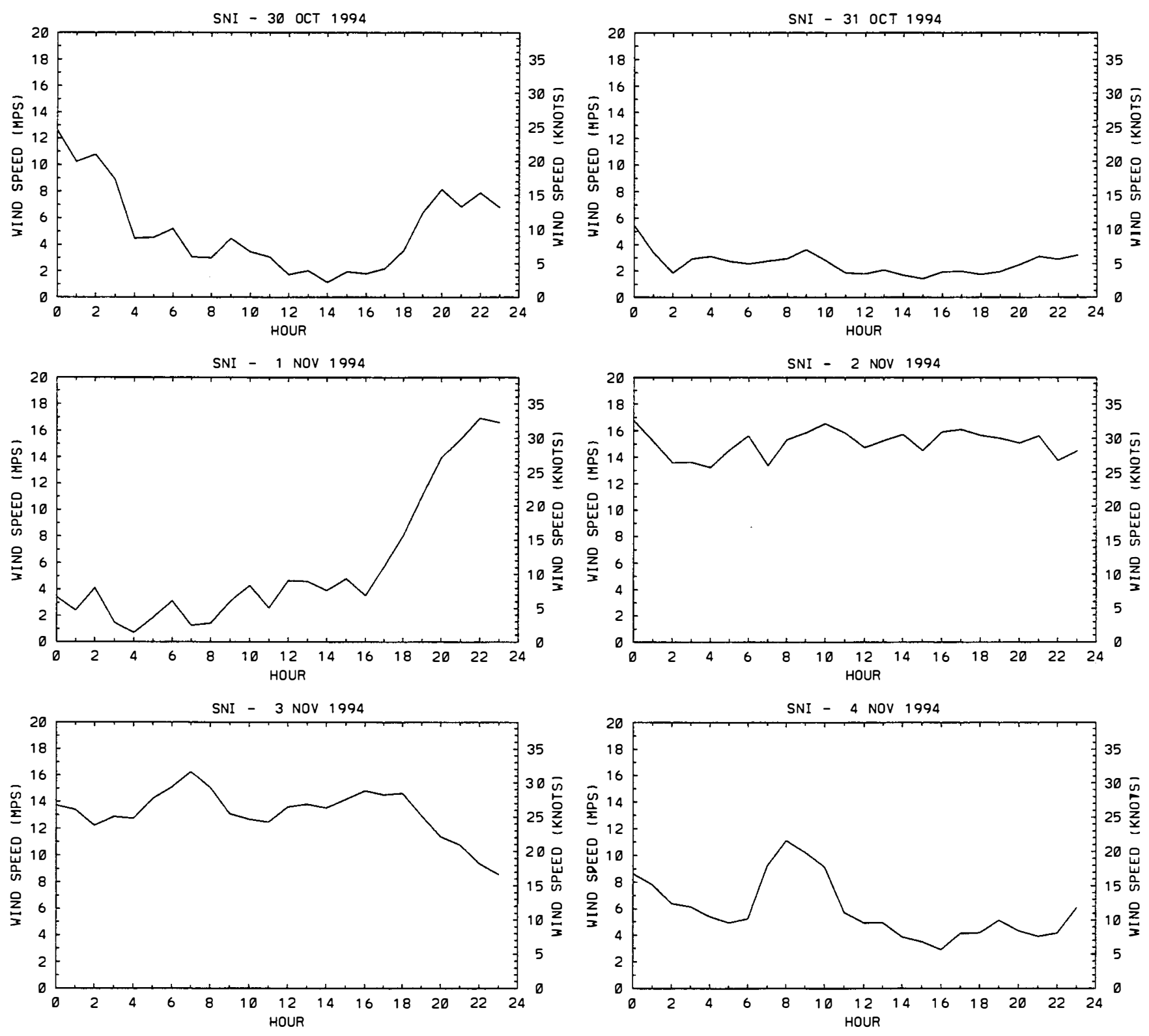

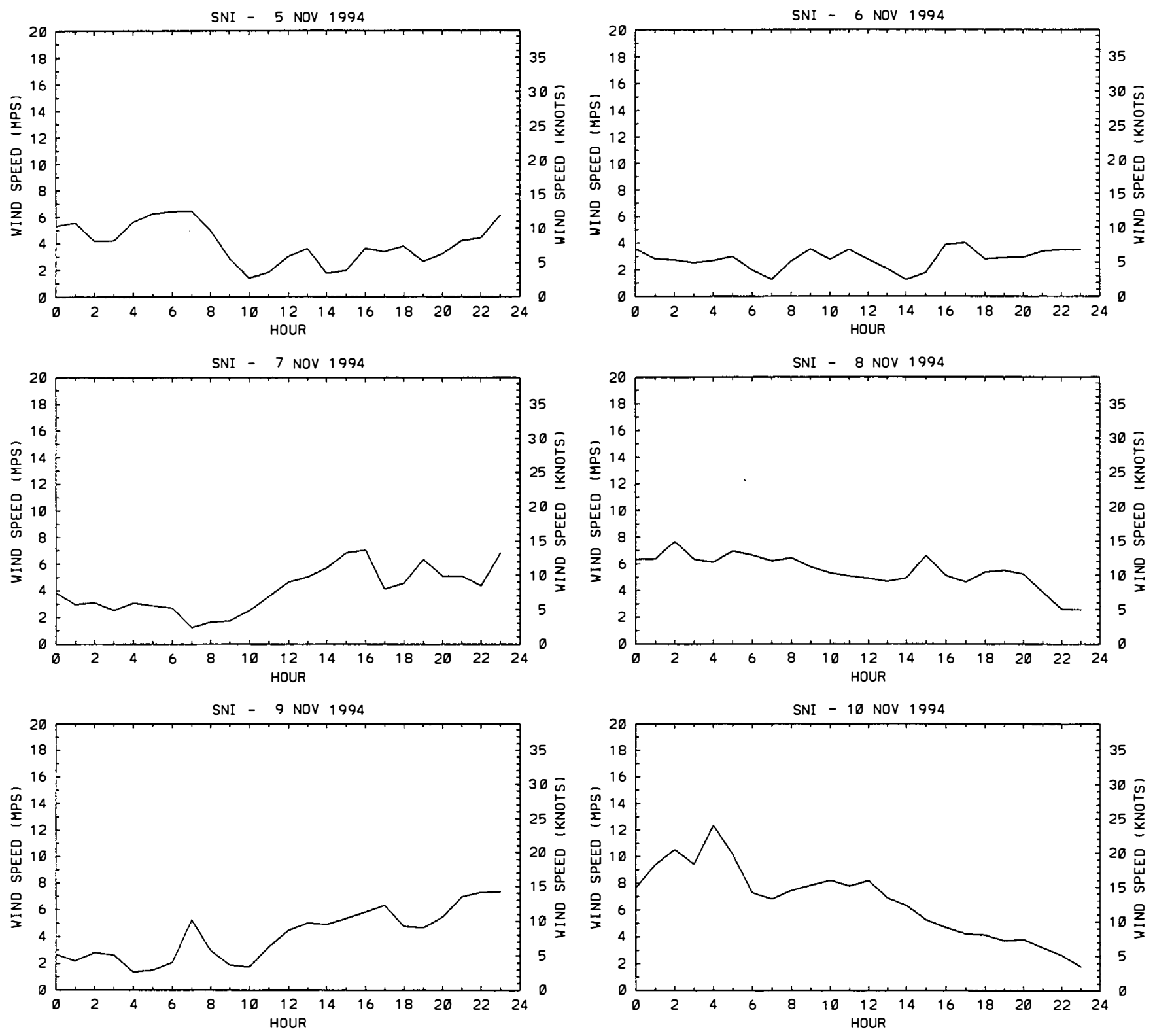

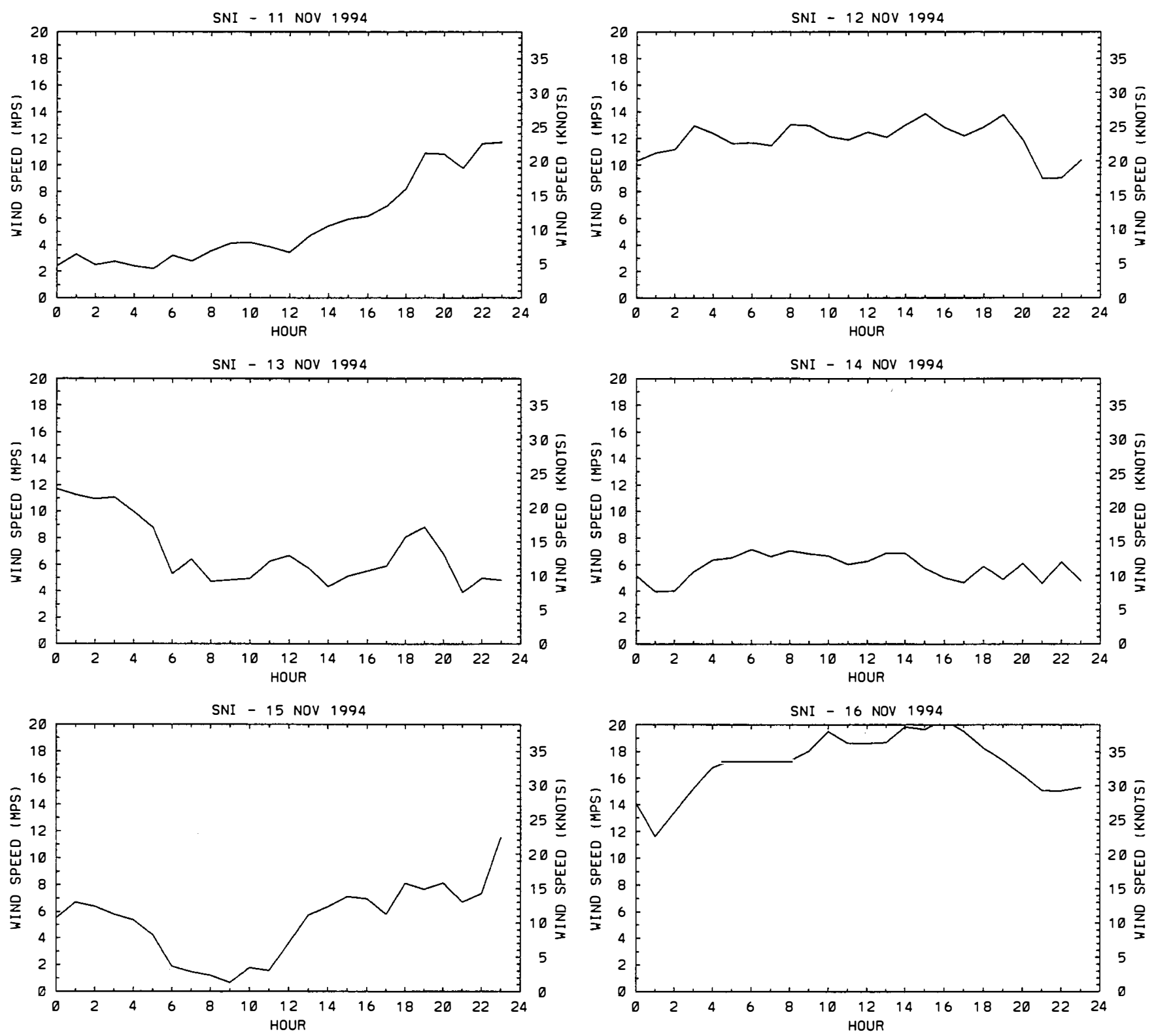
WIND SPEED (MPS)

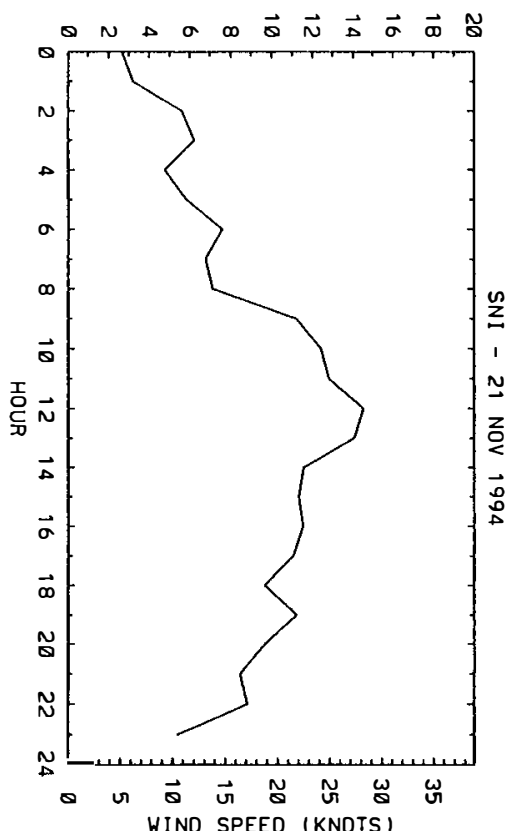

WIND SPEED (MPS)

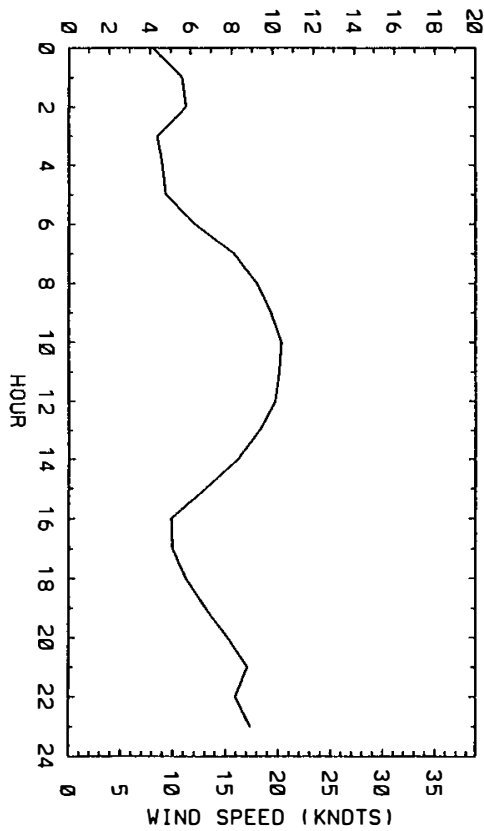

WIND SPEED (MPS)

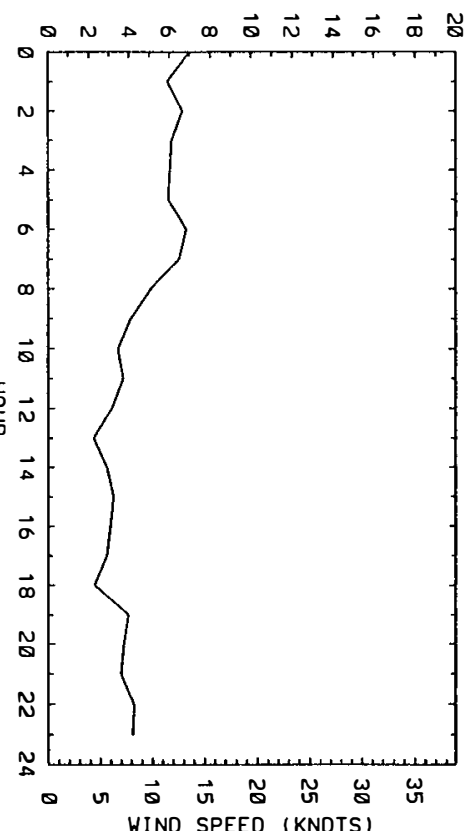

WIND SPEED (MPS)

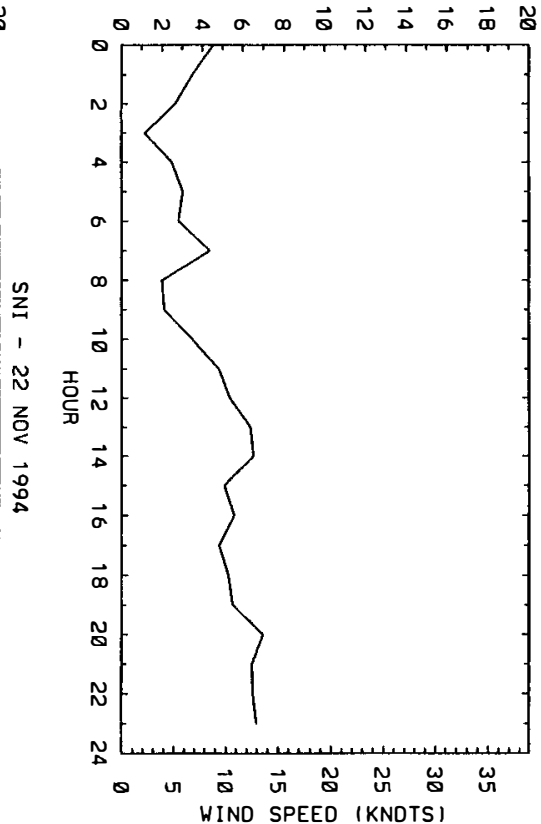

WIND SPEED (MPS)

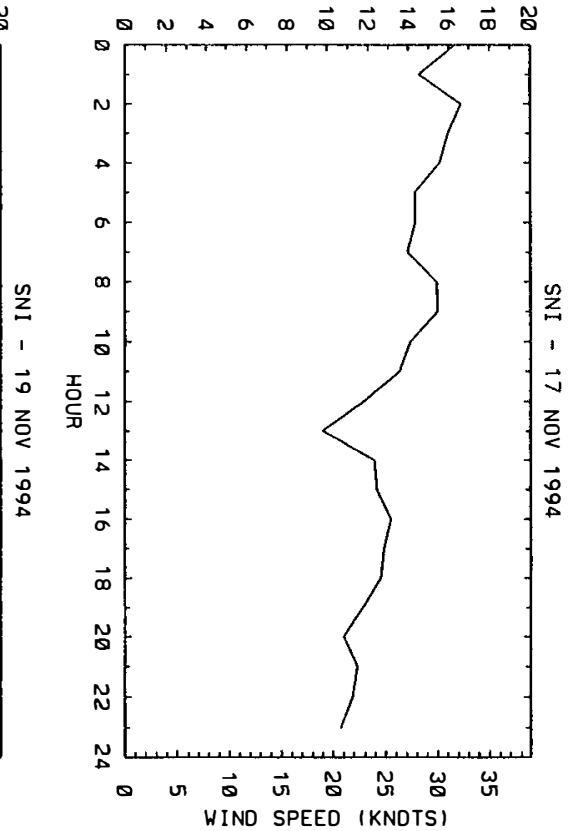

WIND SPEED (MPS)

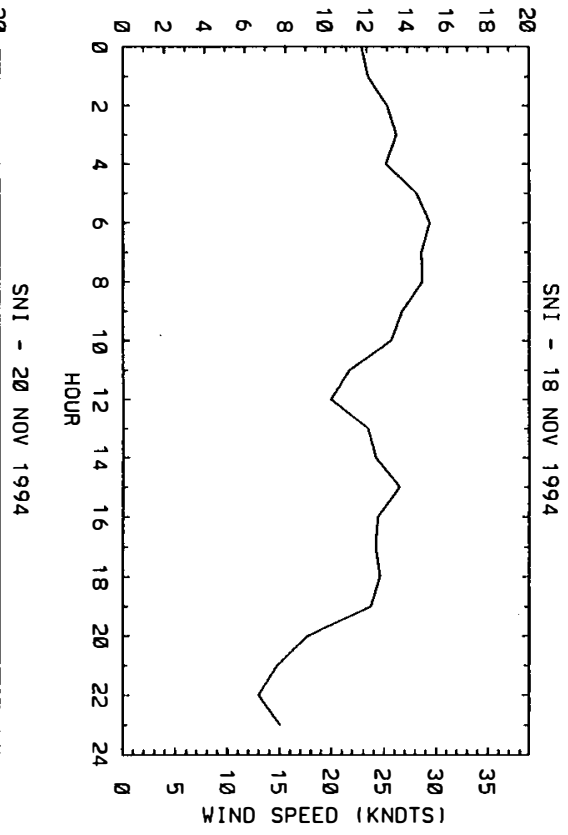



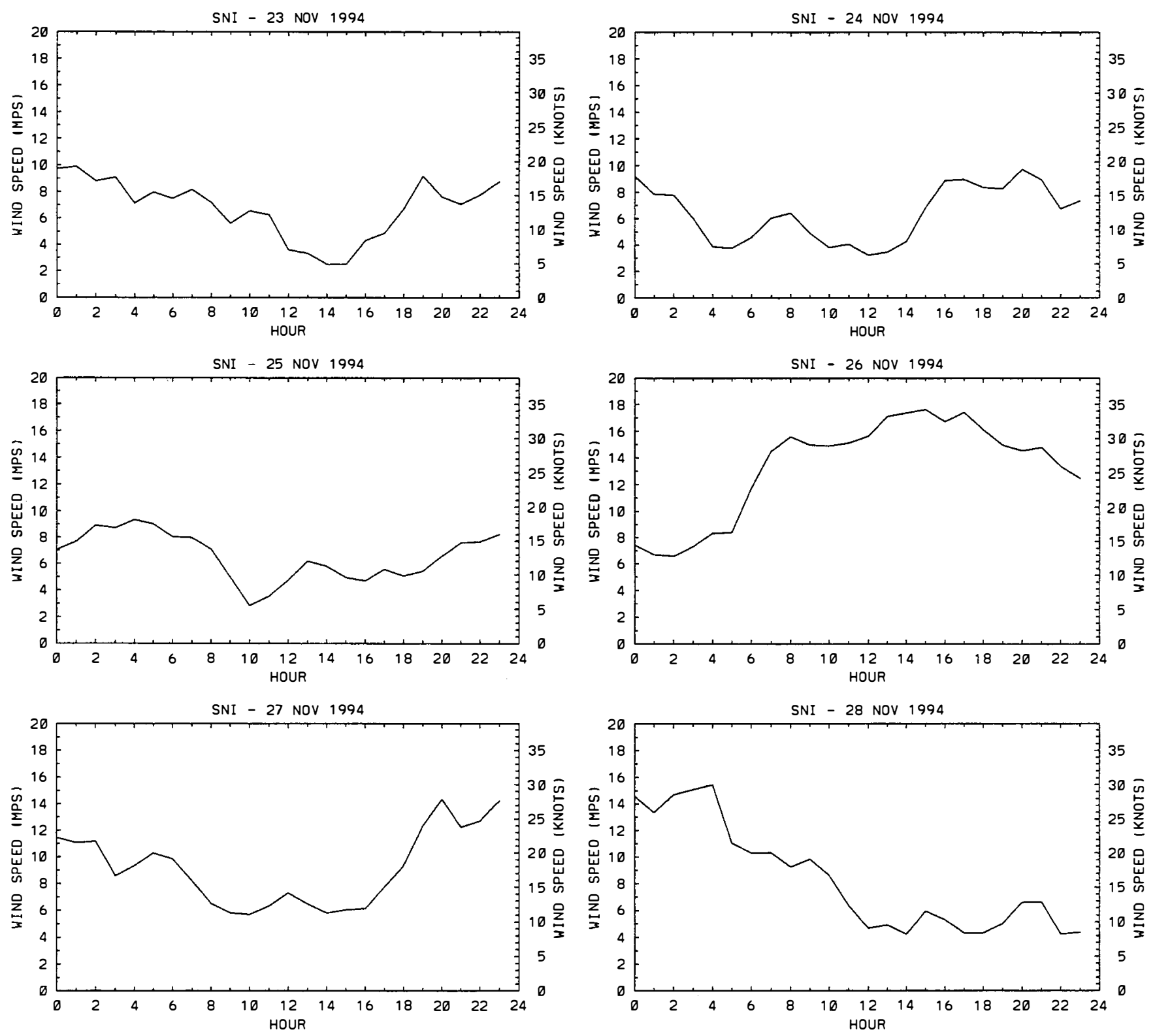

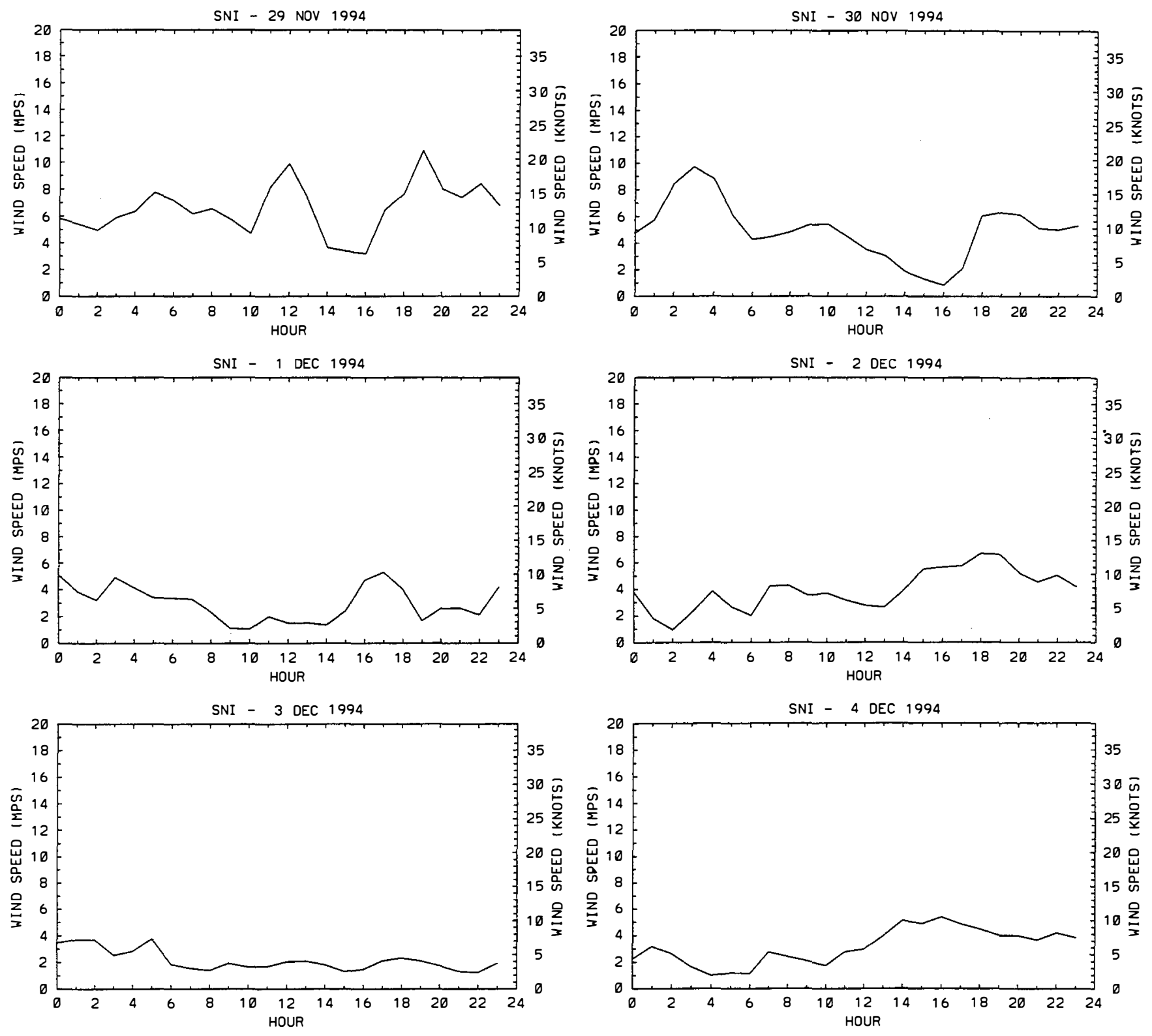

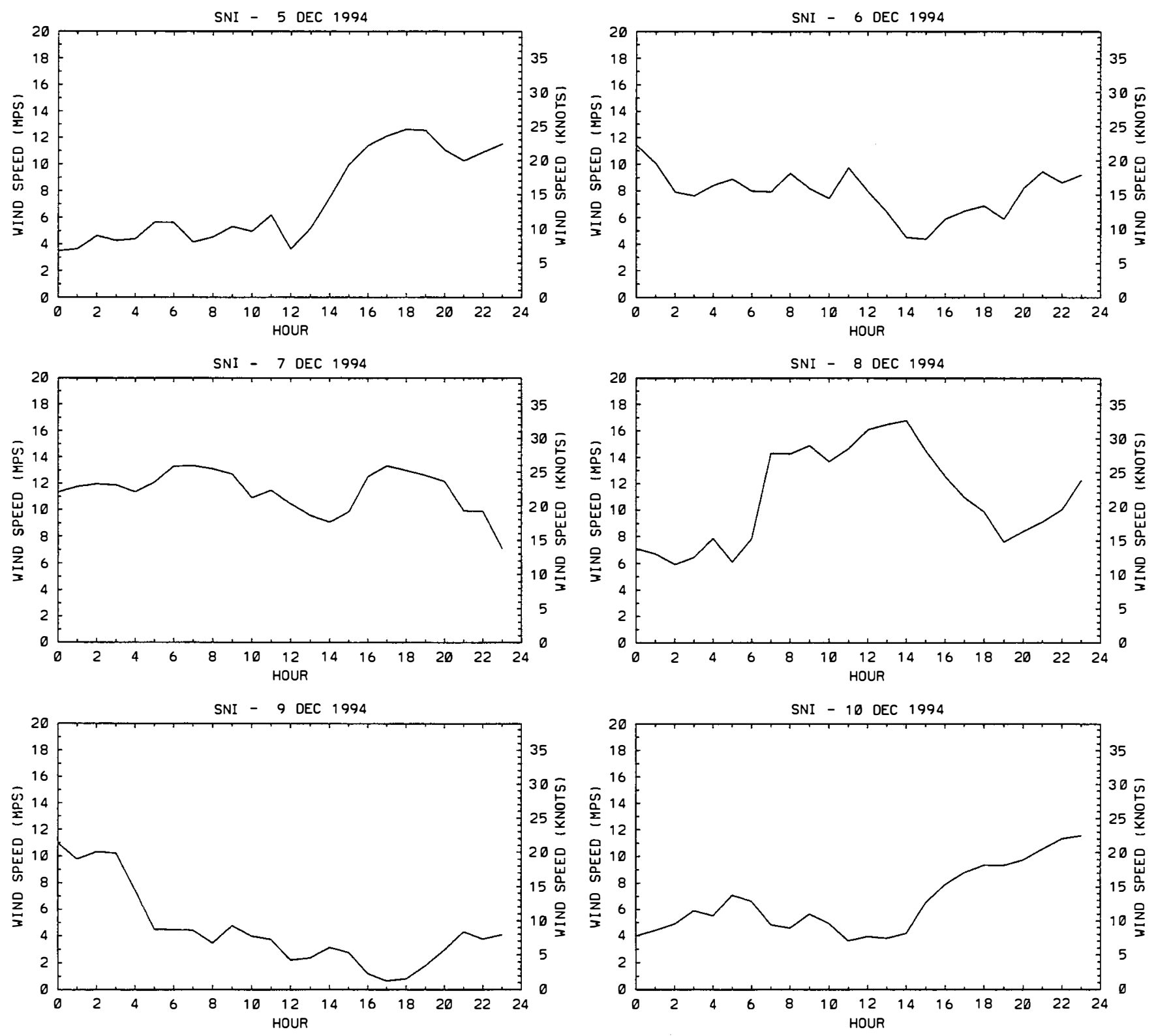

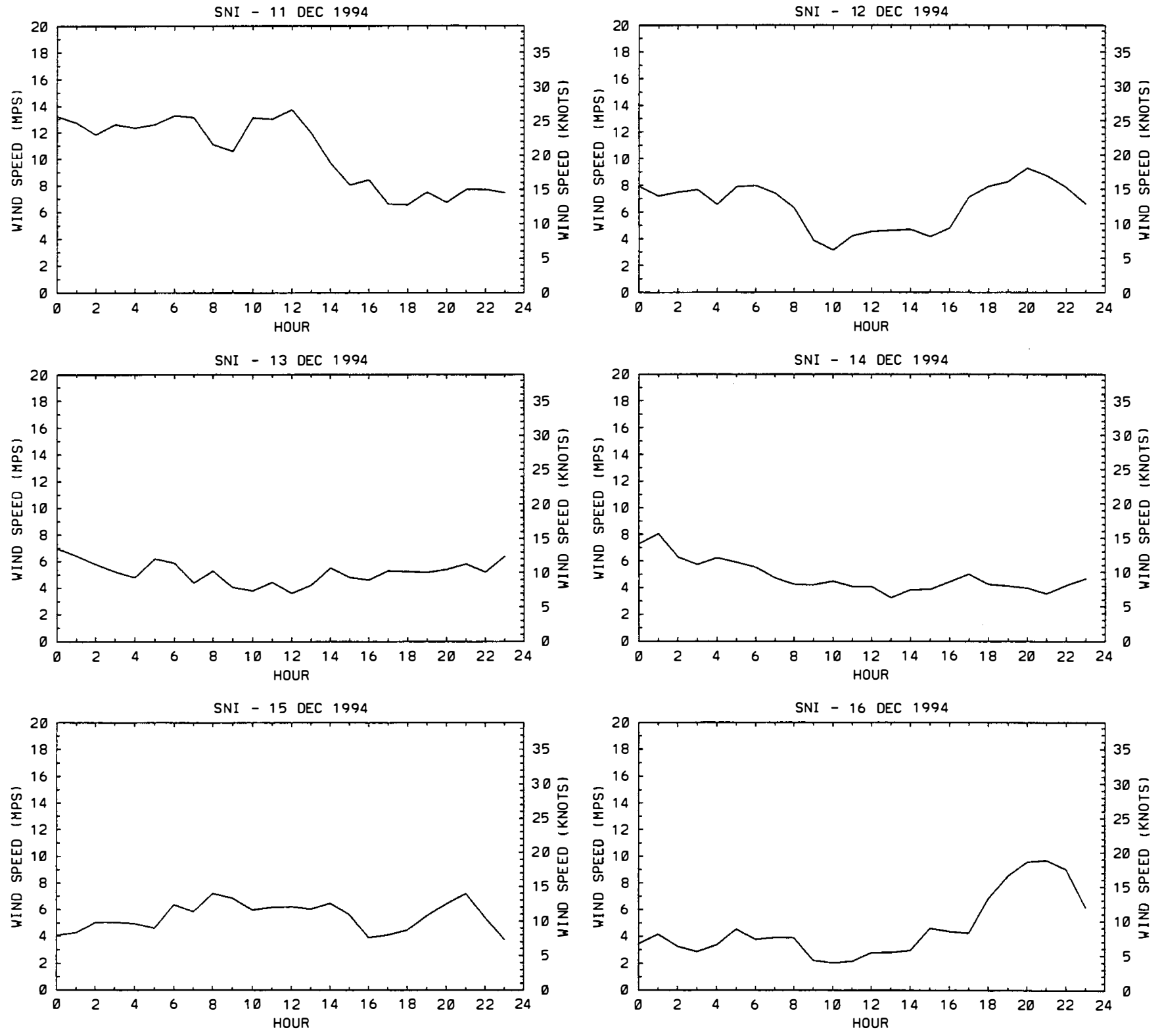

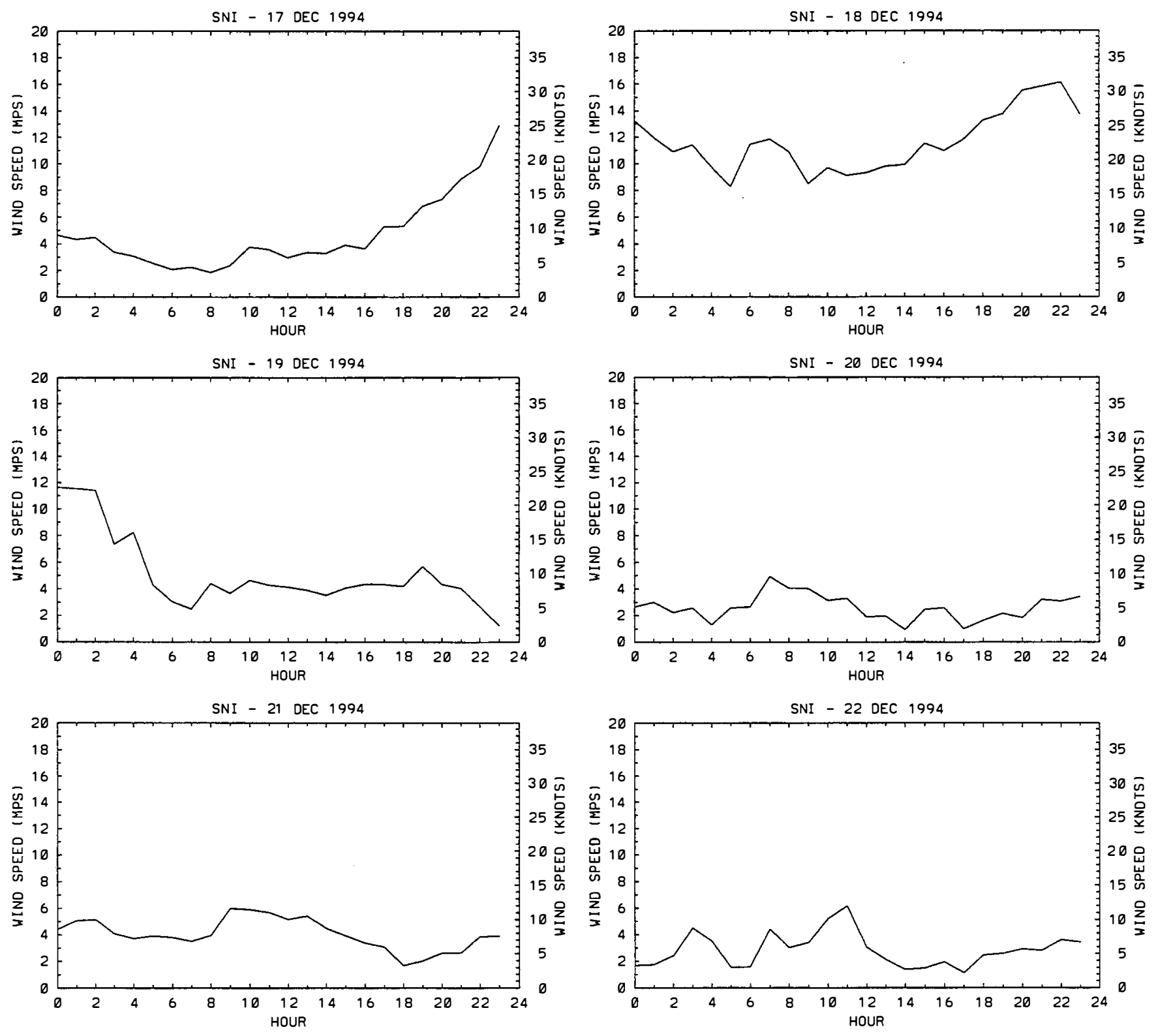

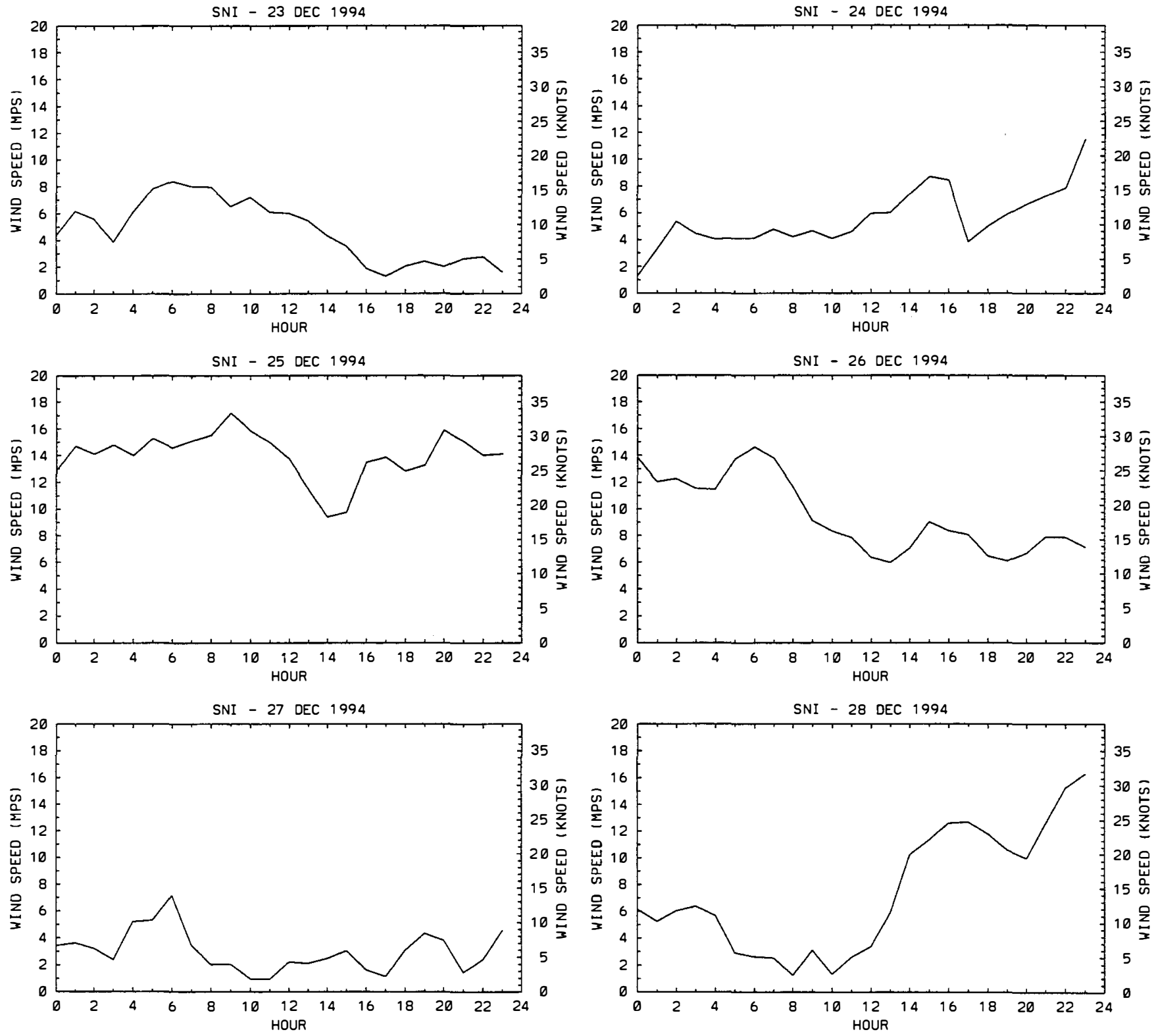

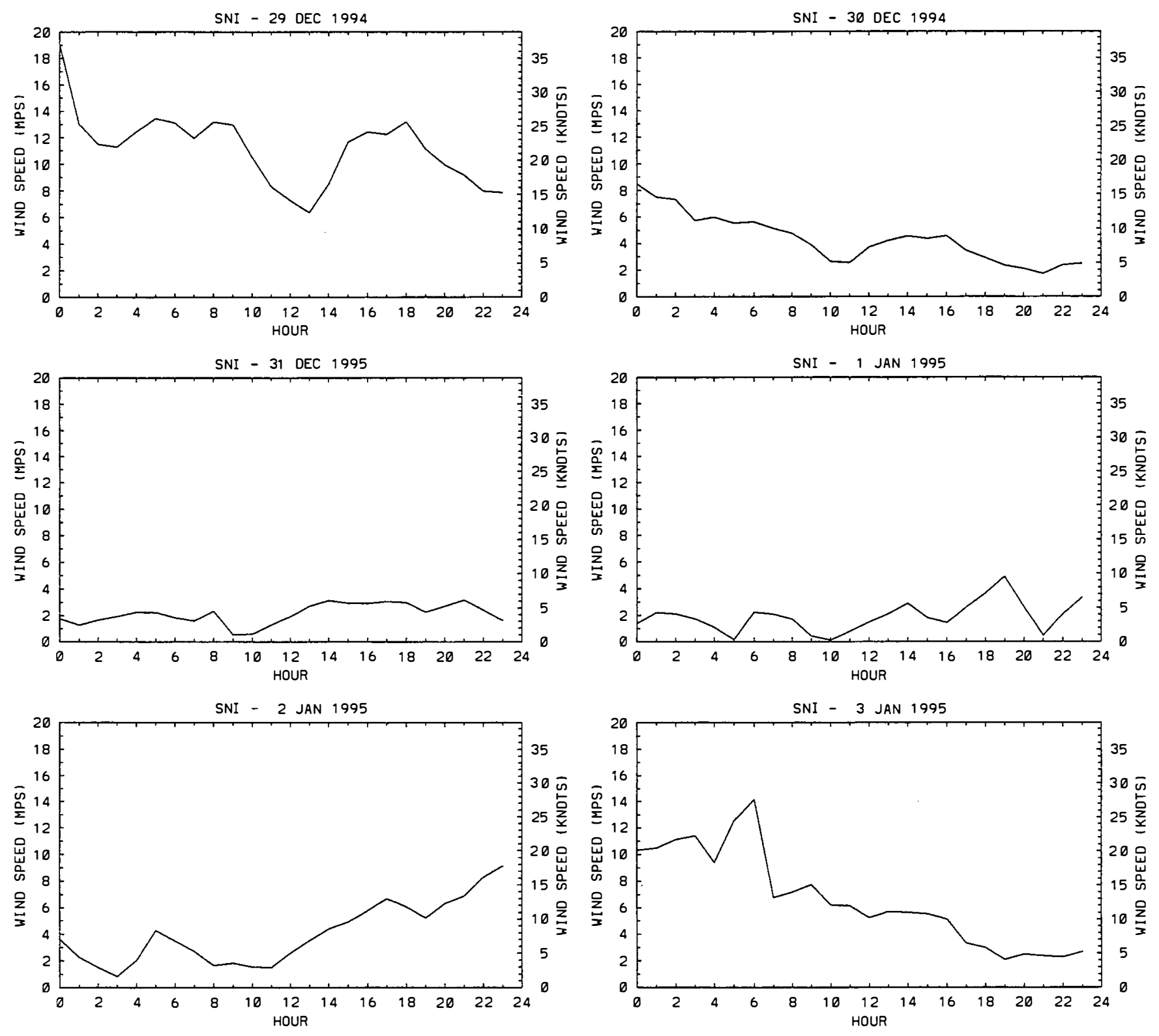

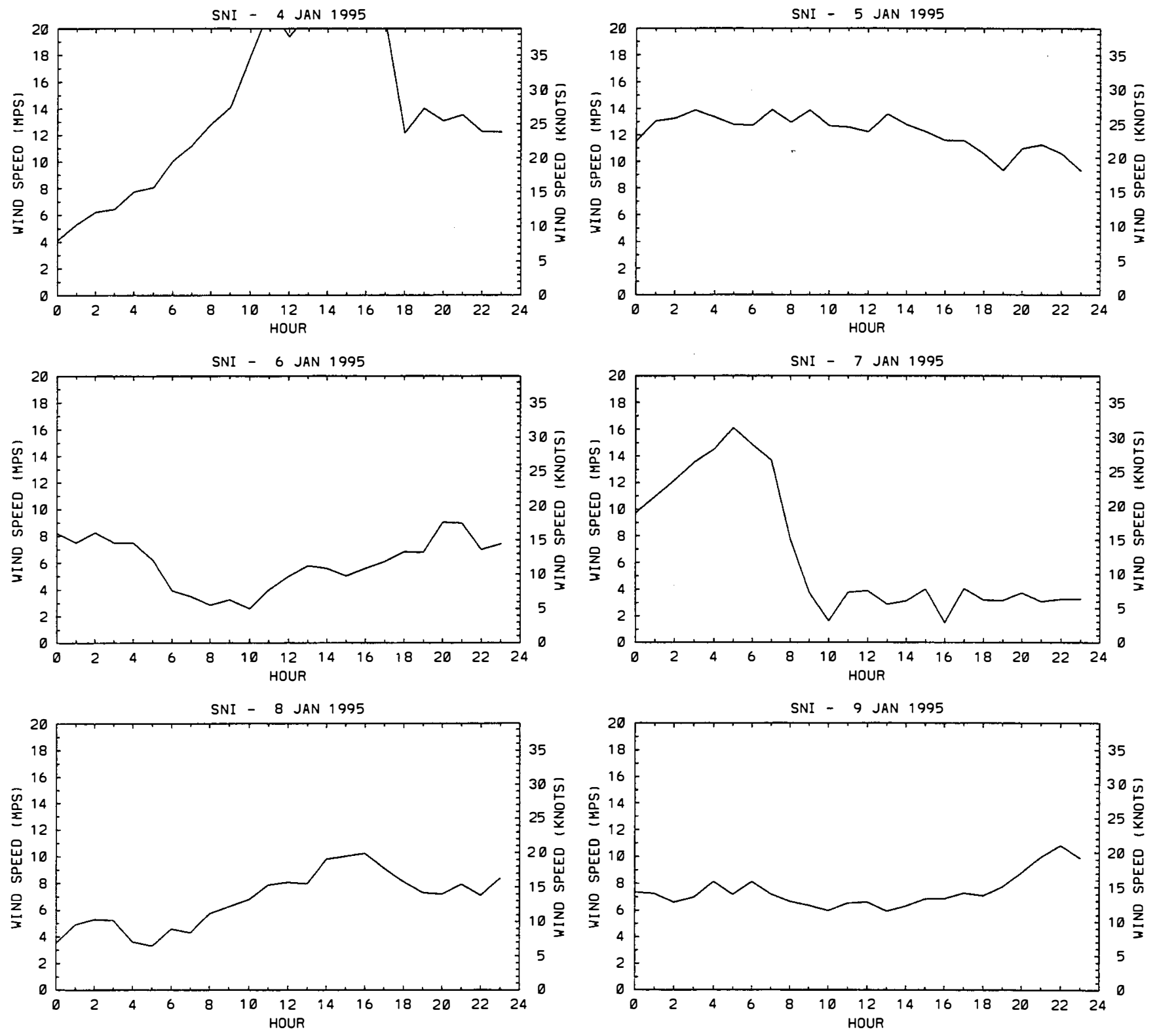

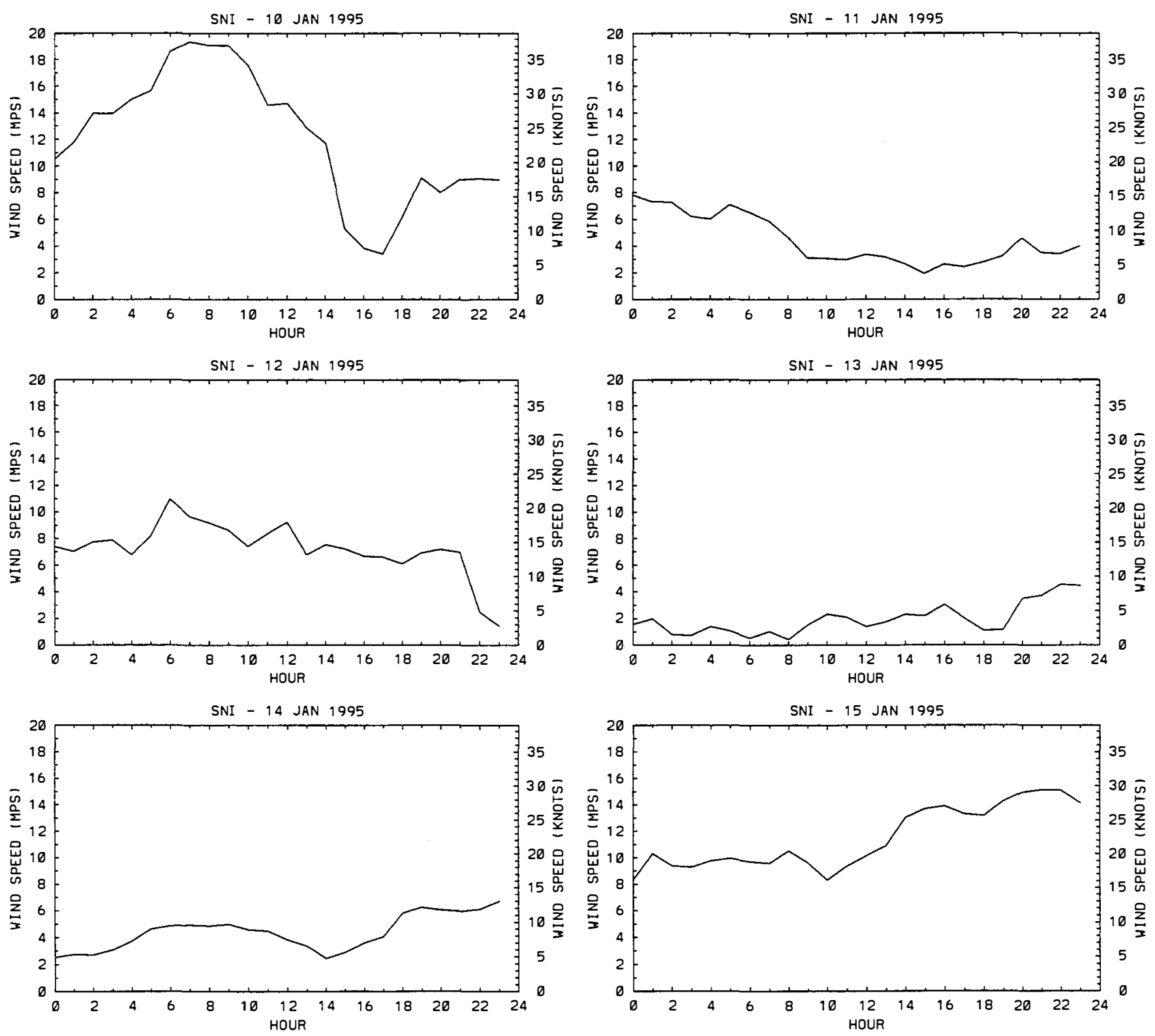

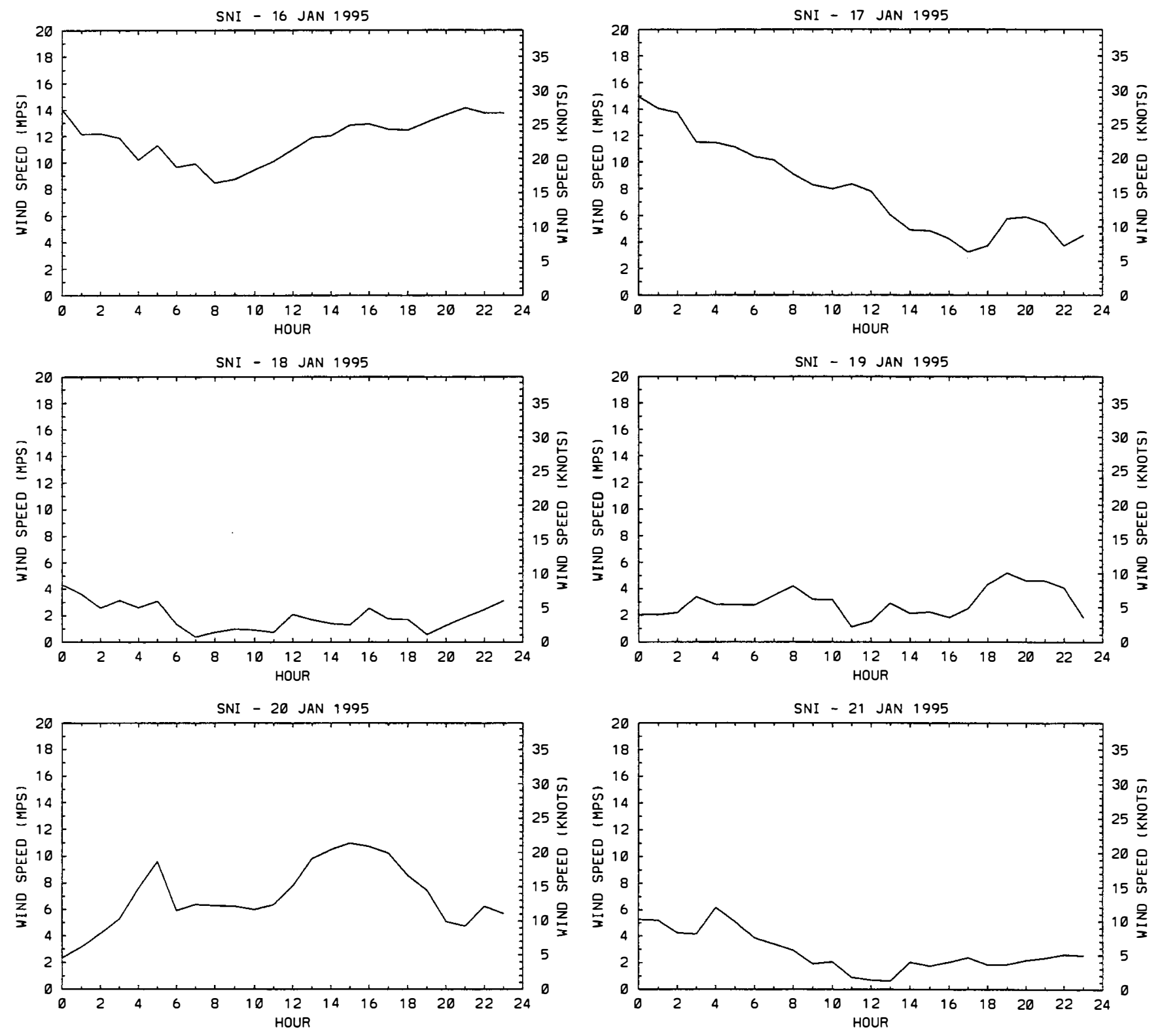

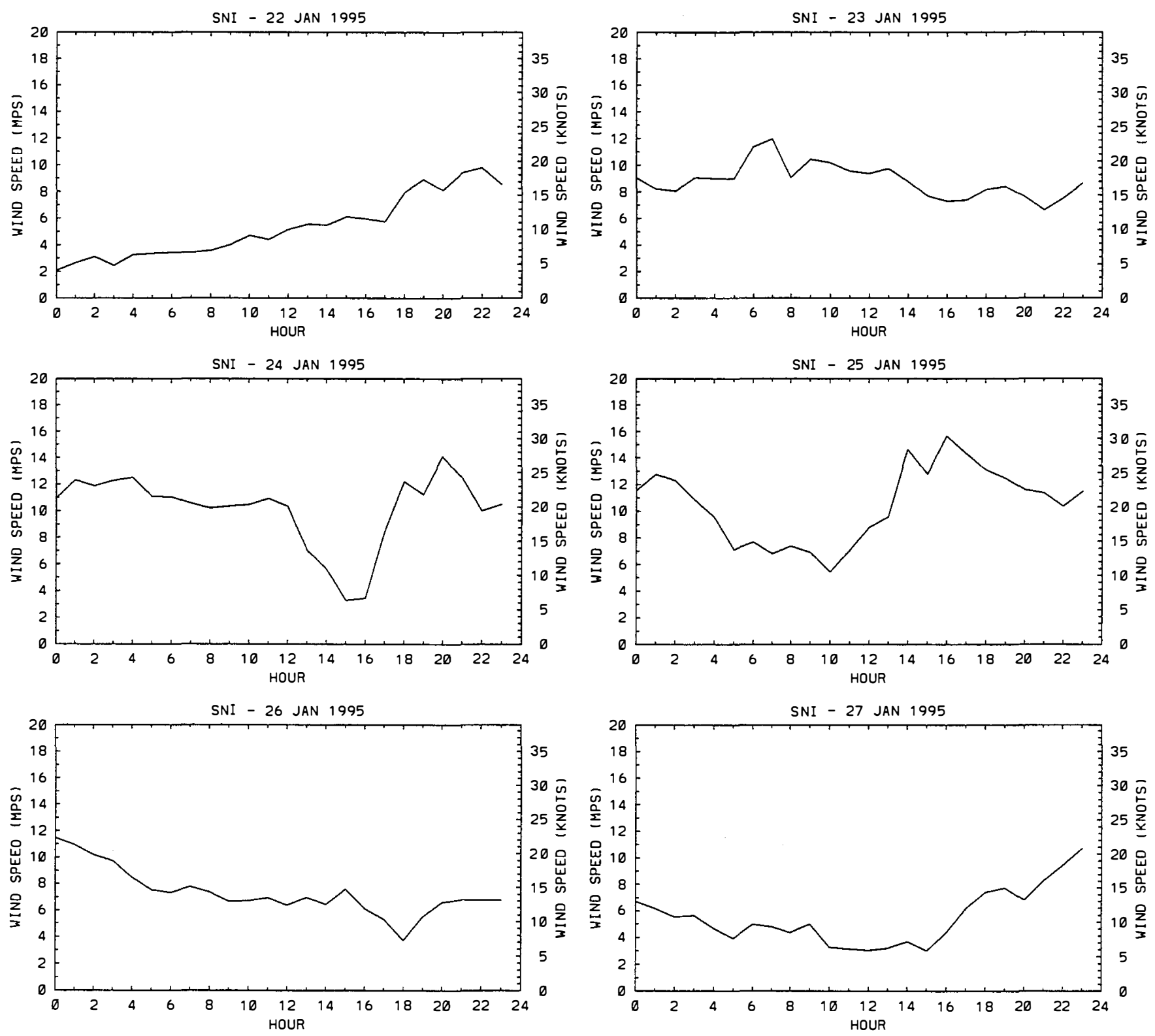

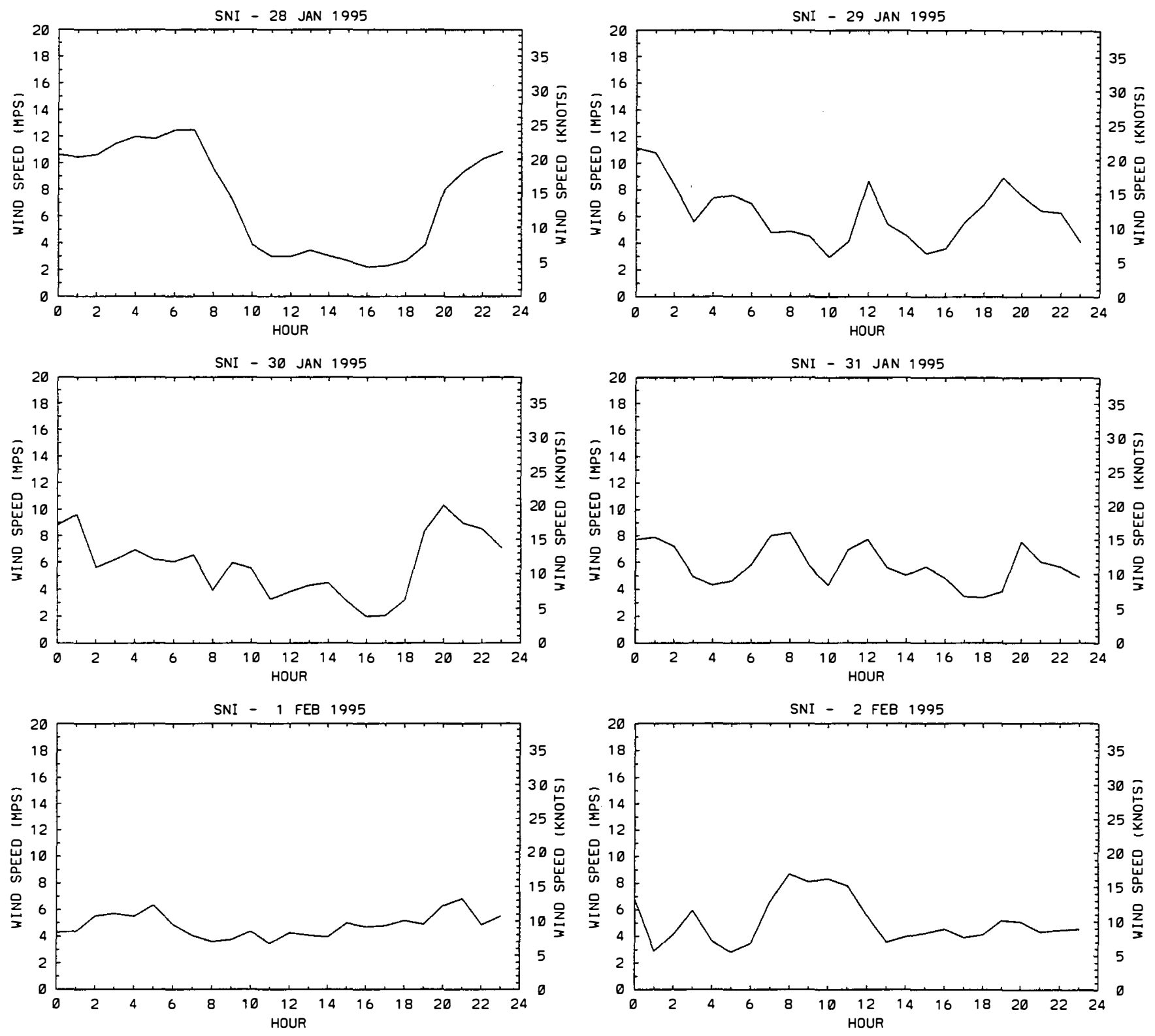

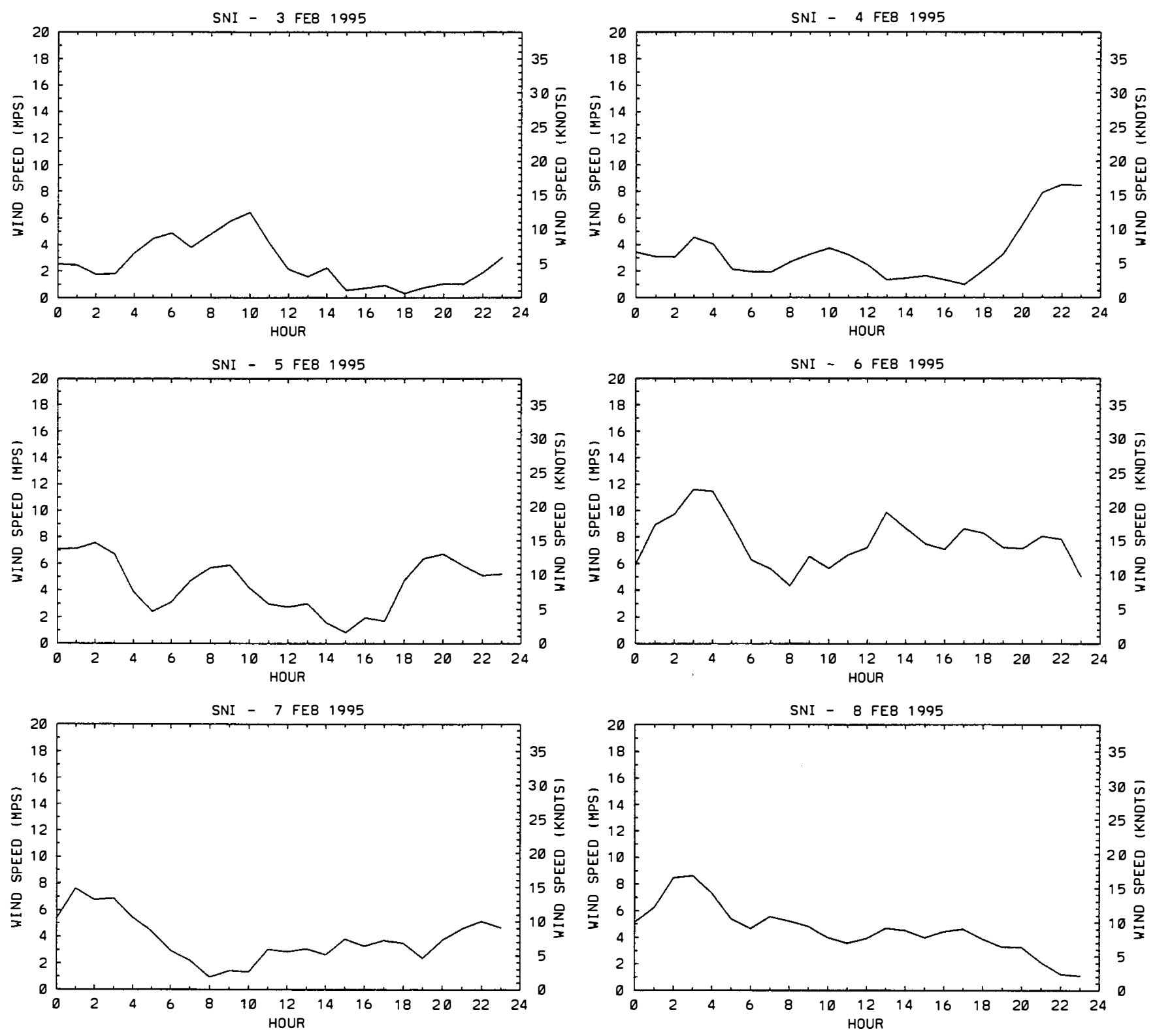

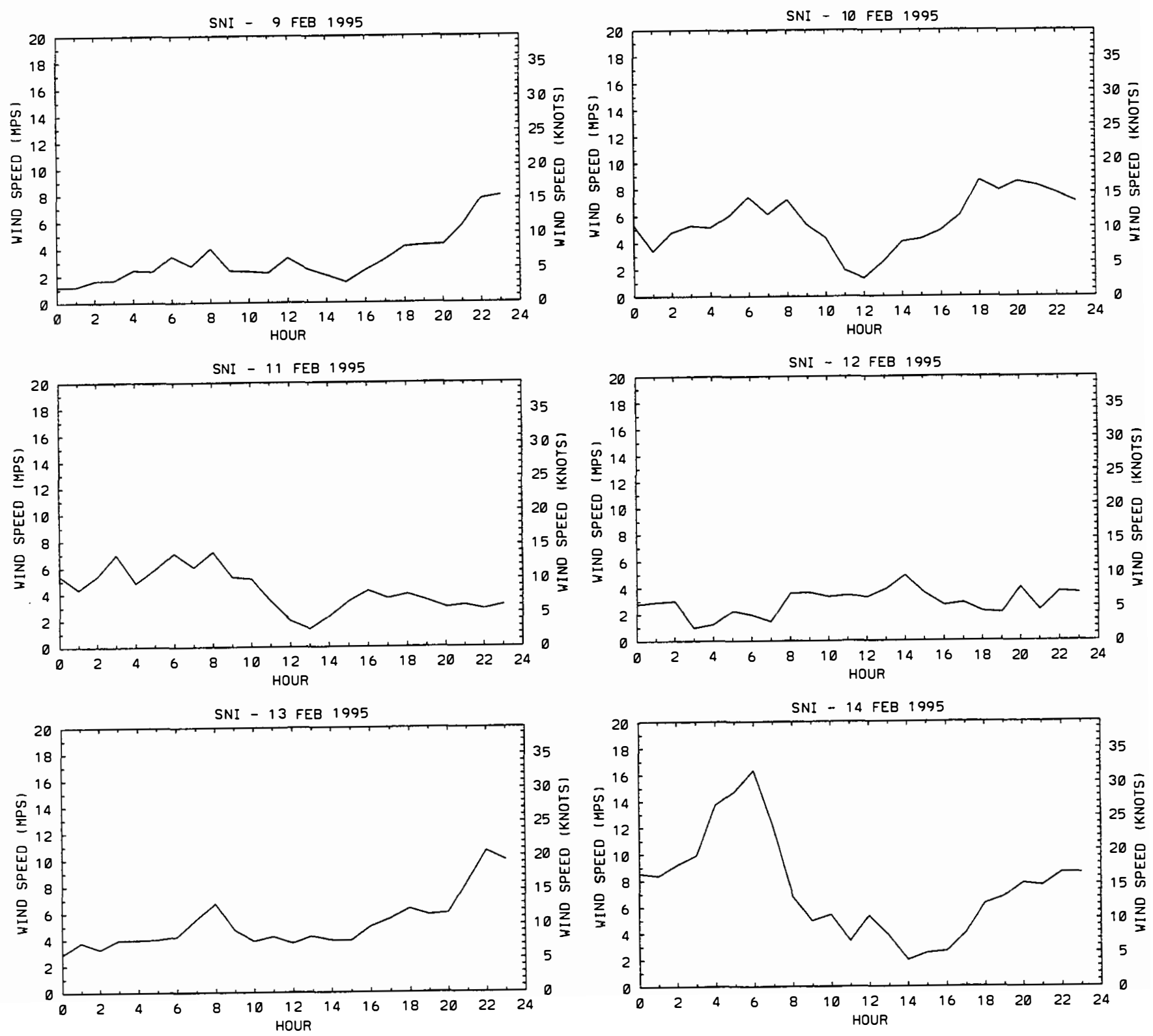

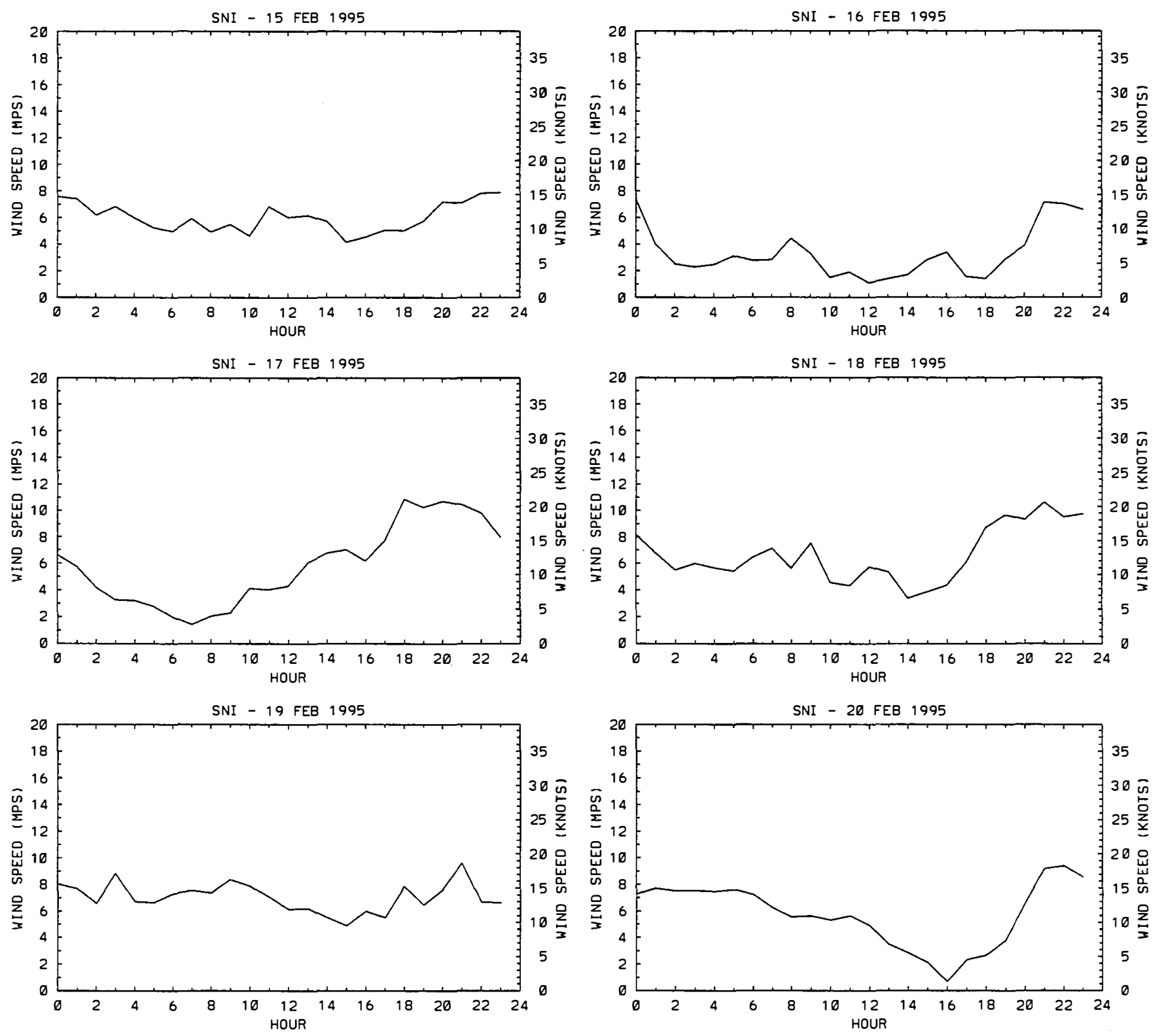

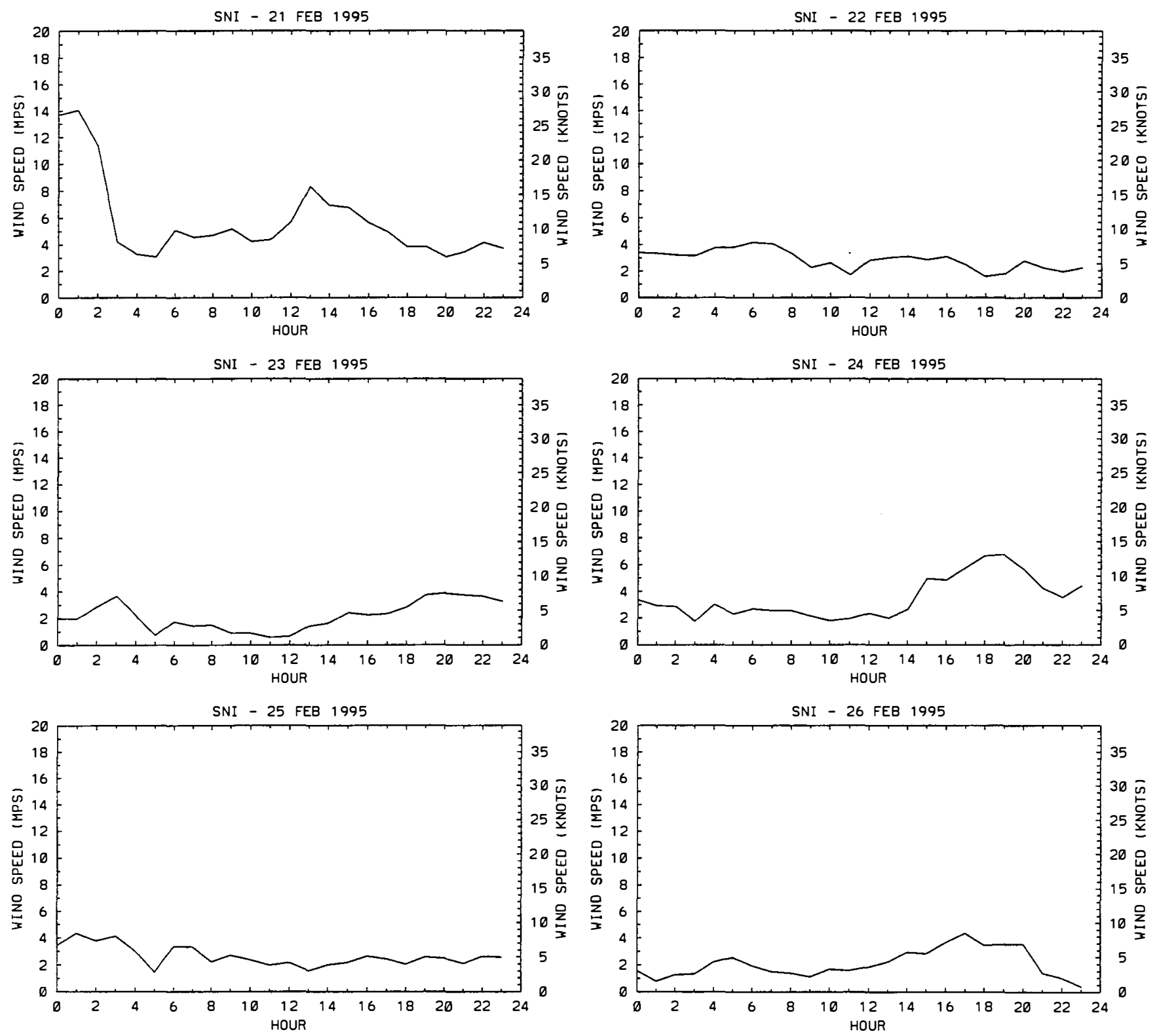

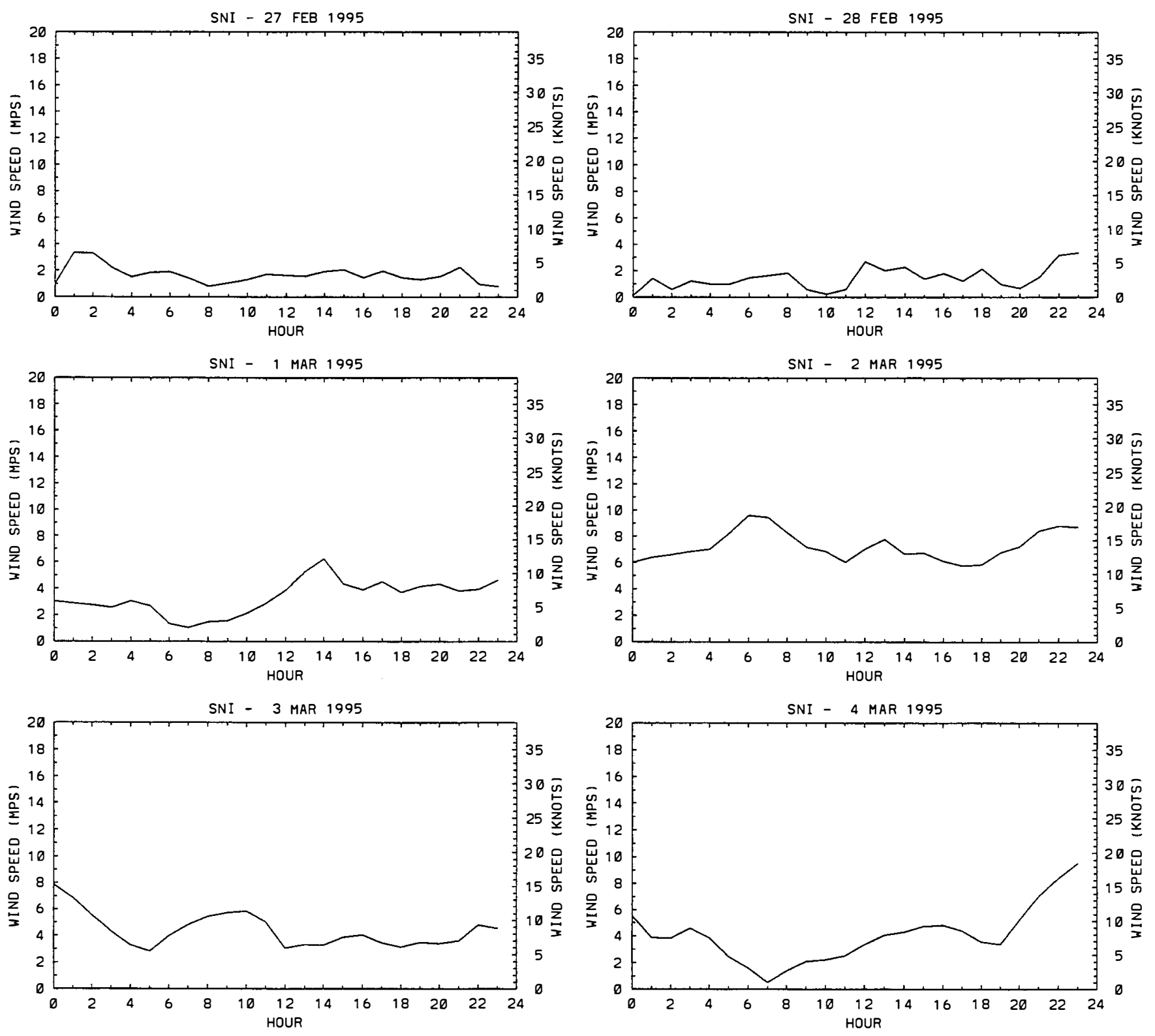

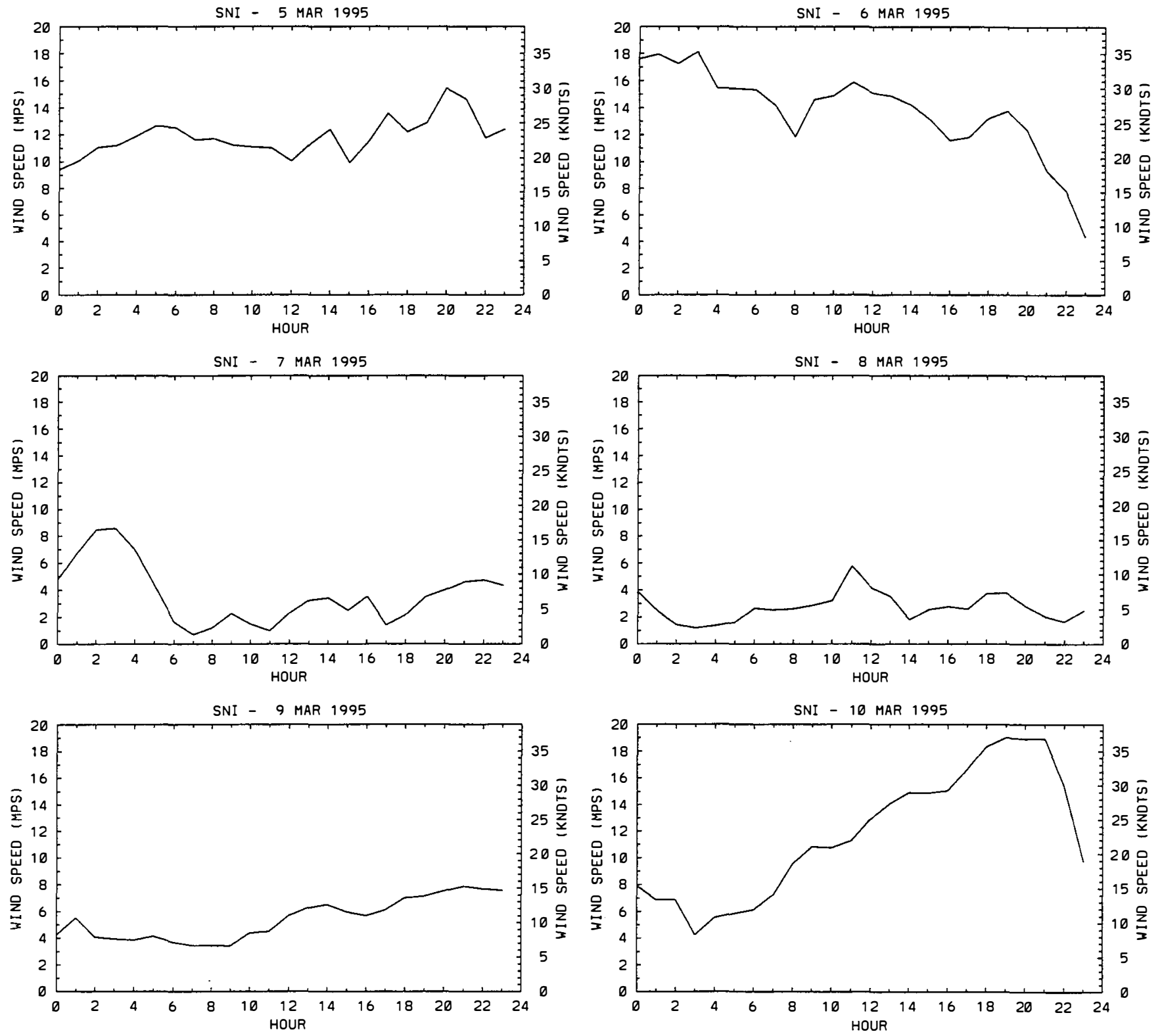

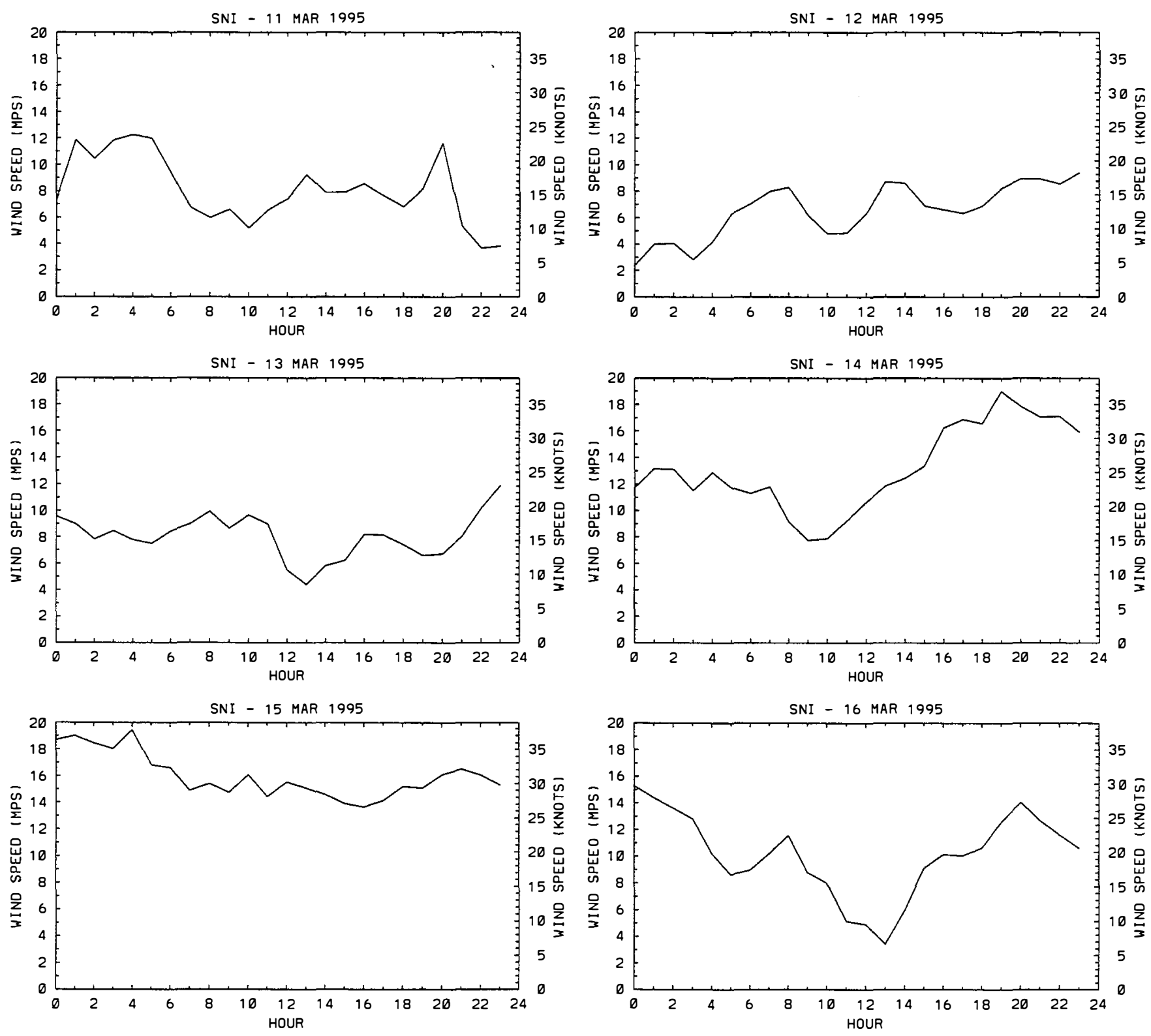

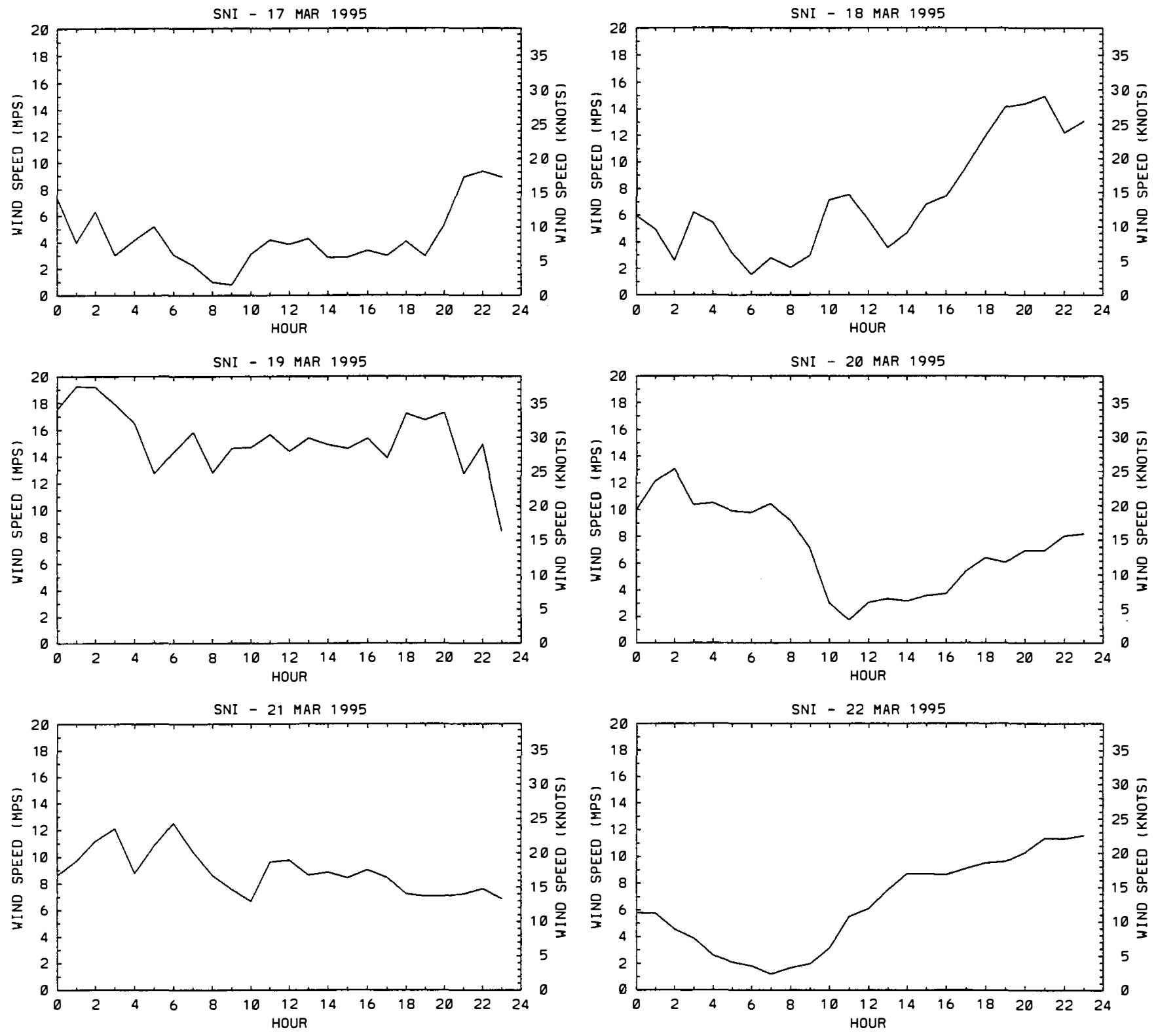

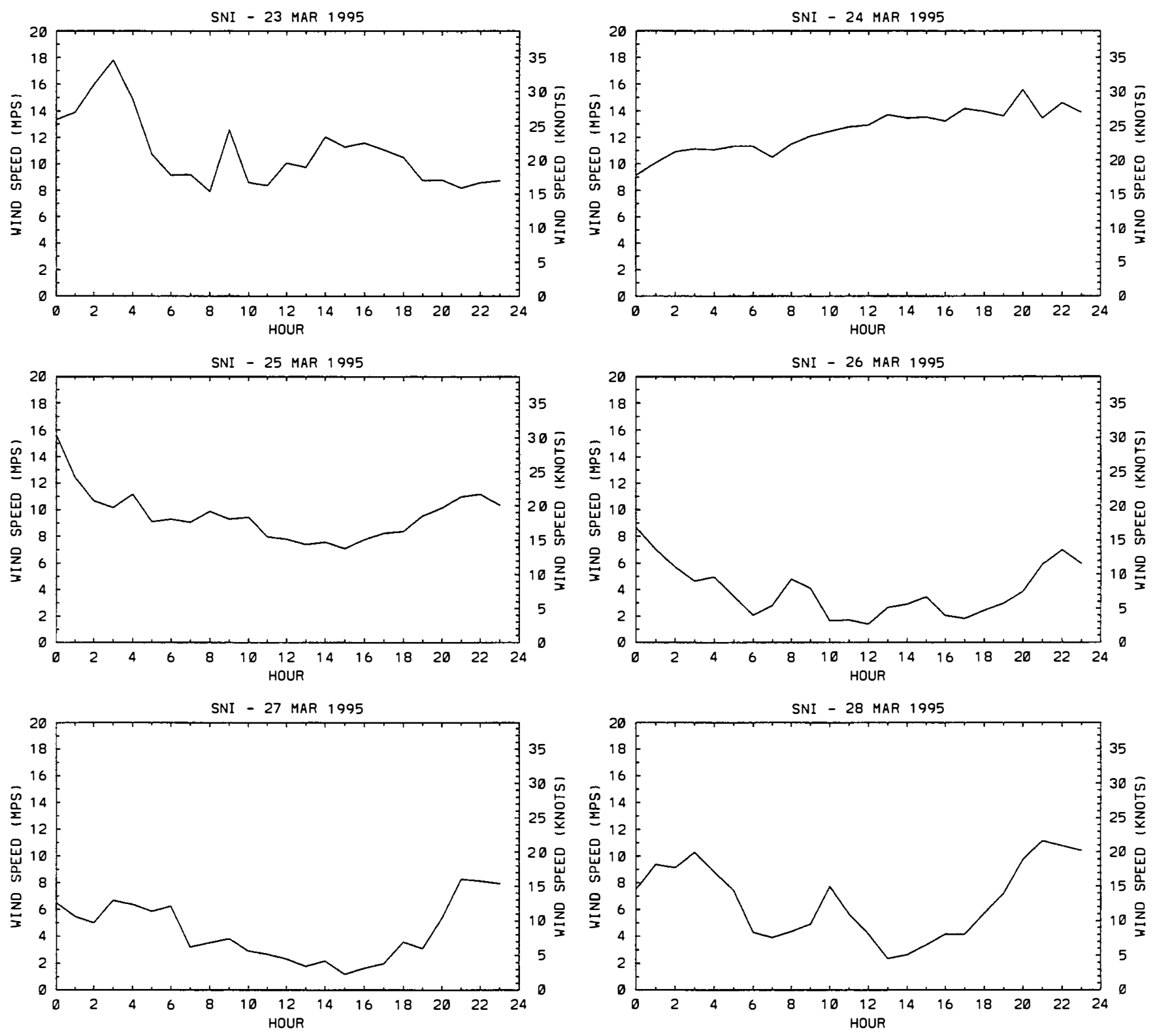

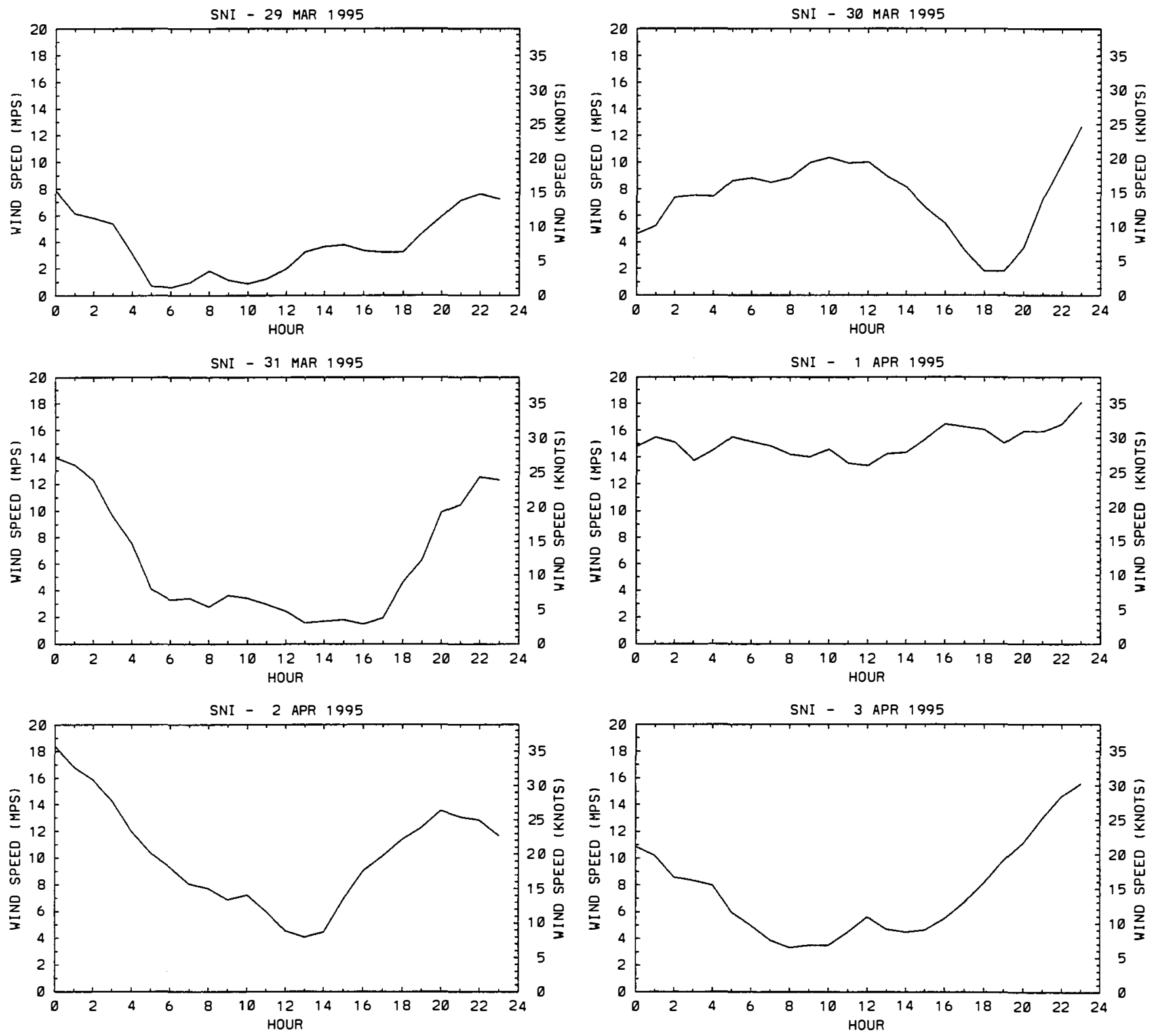

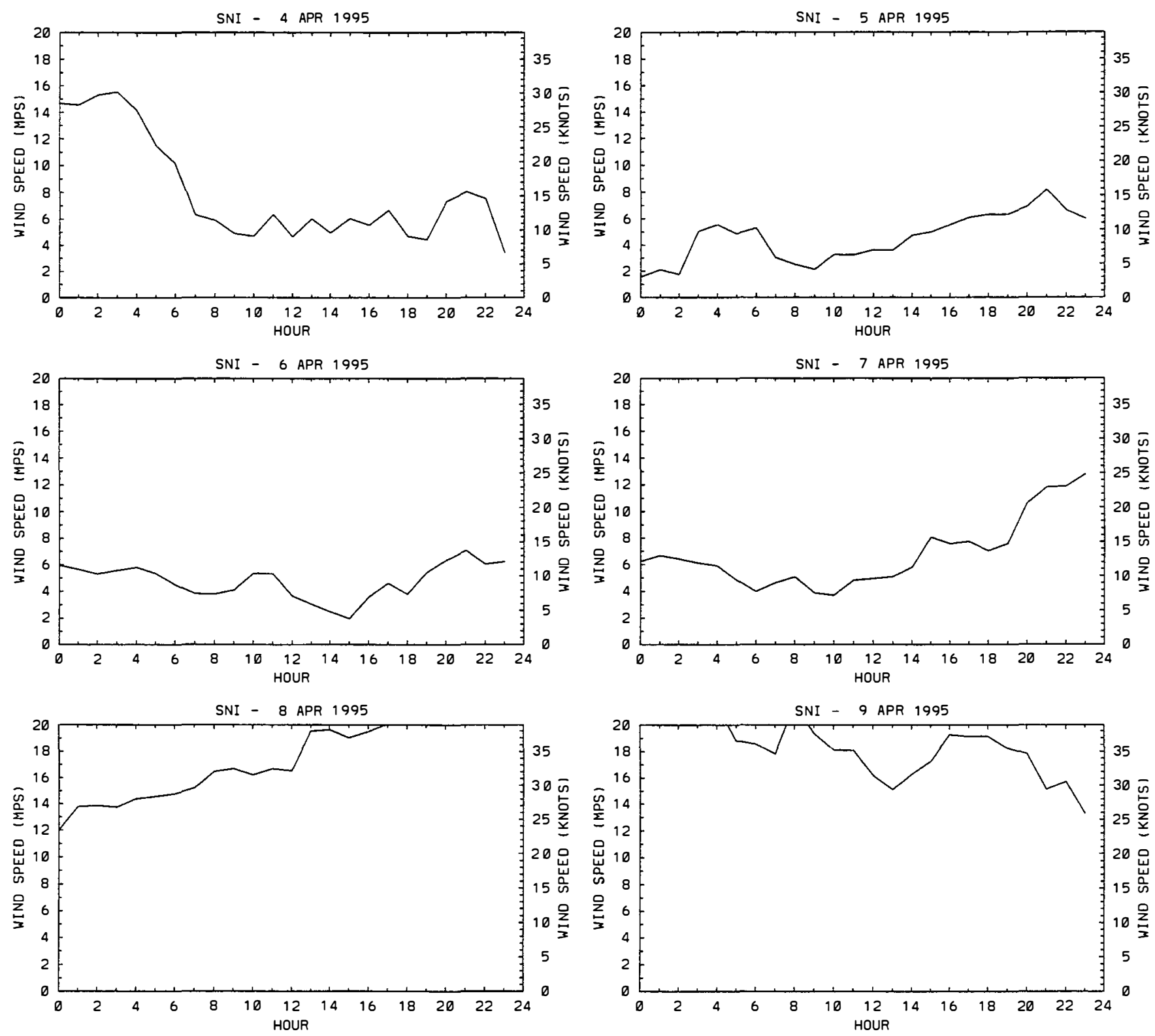

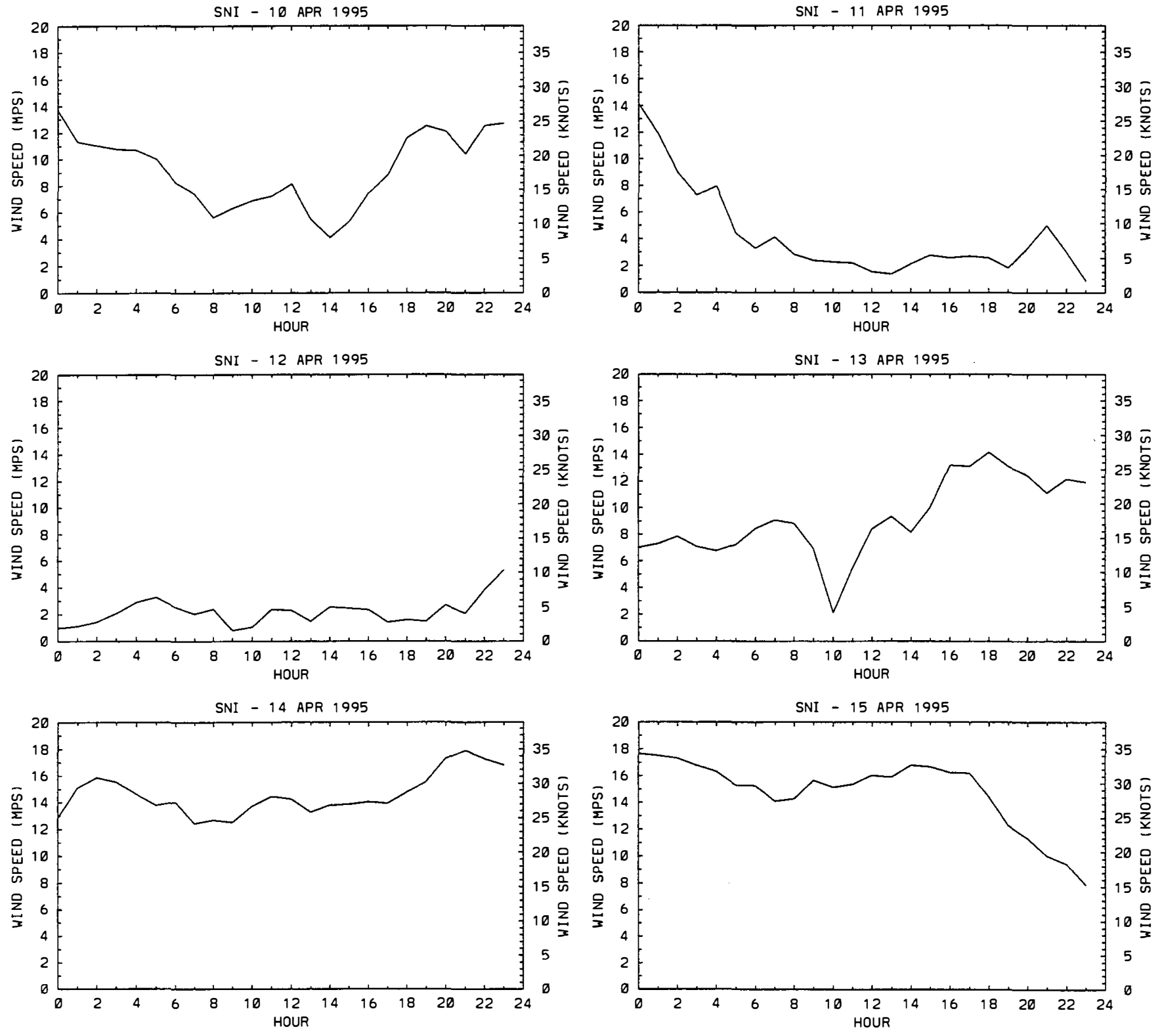

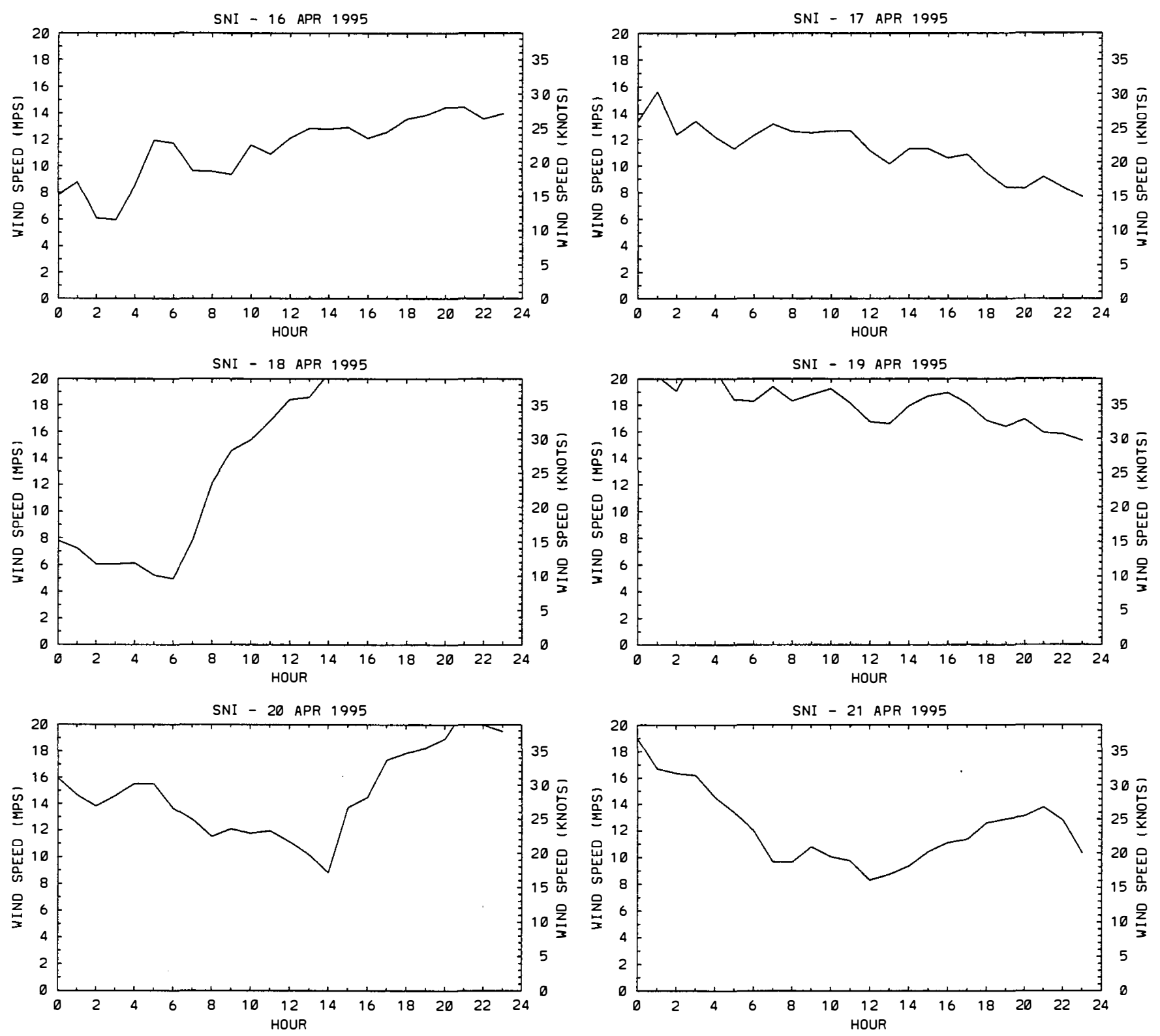

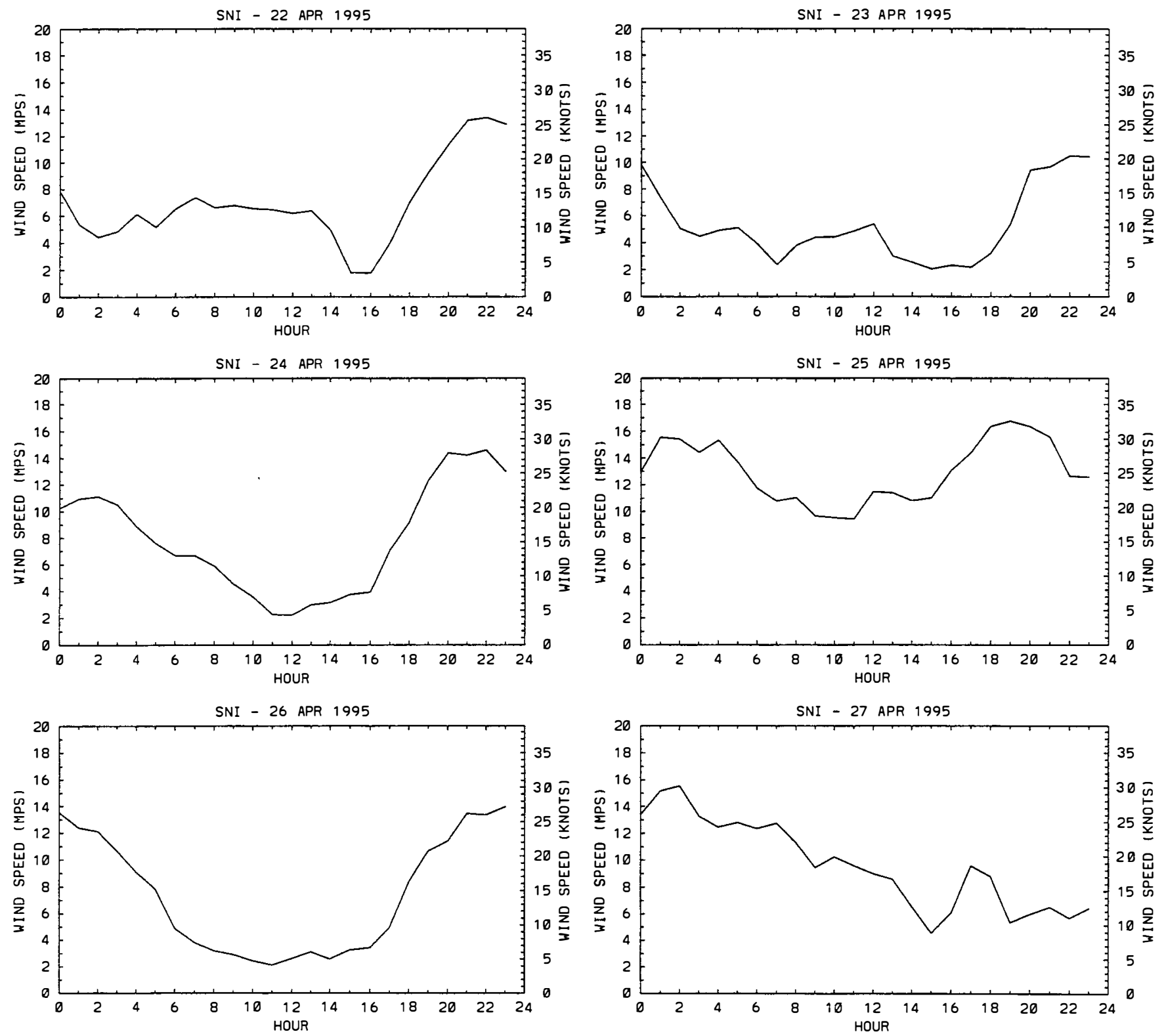

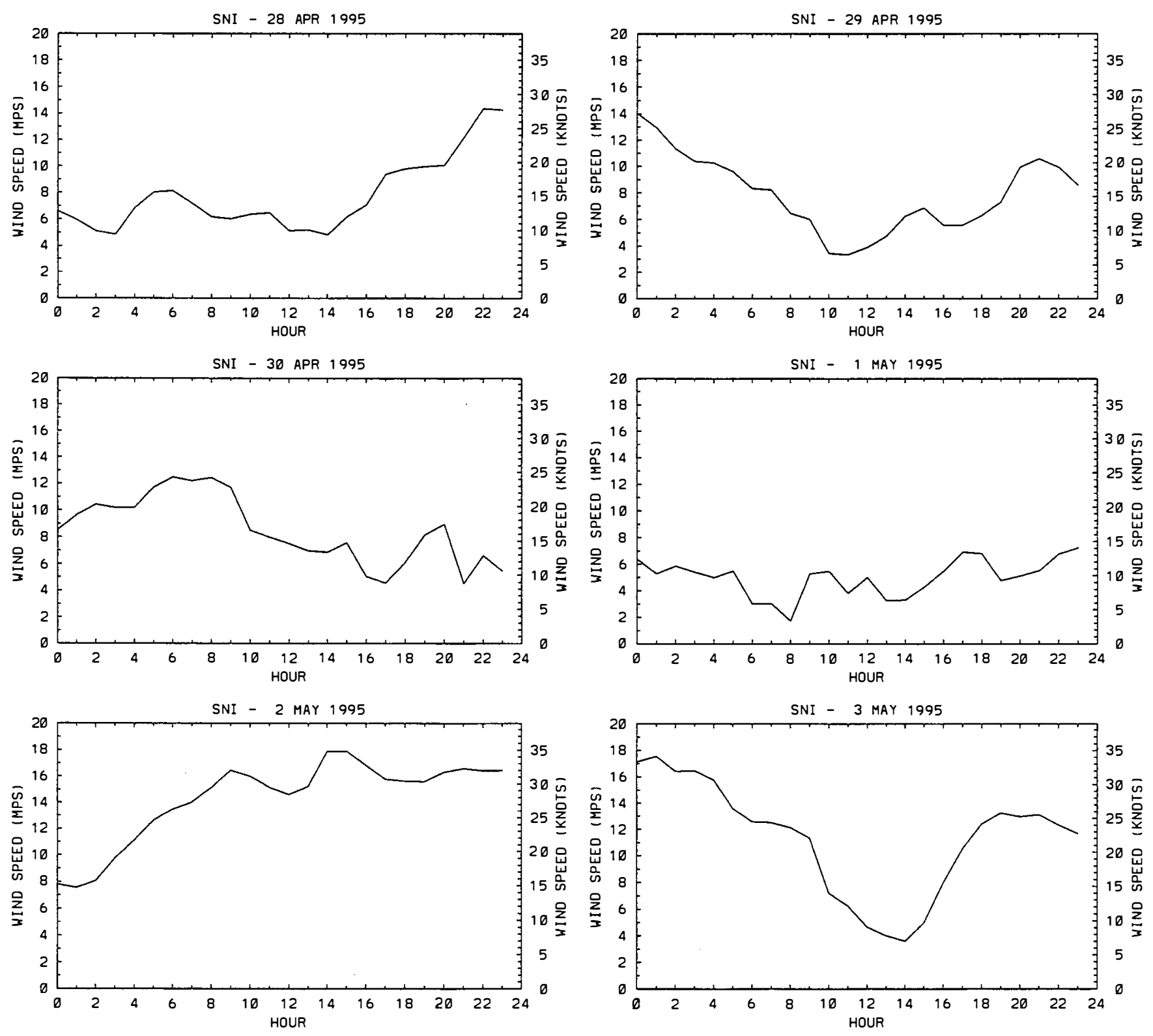

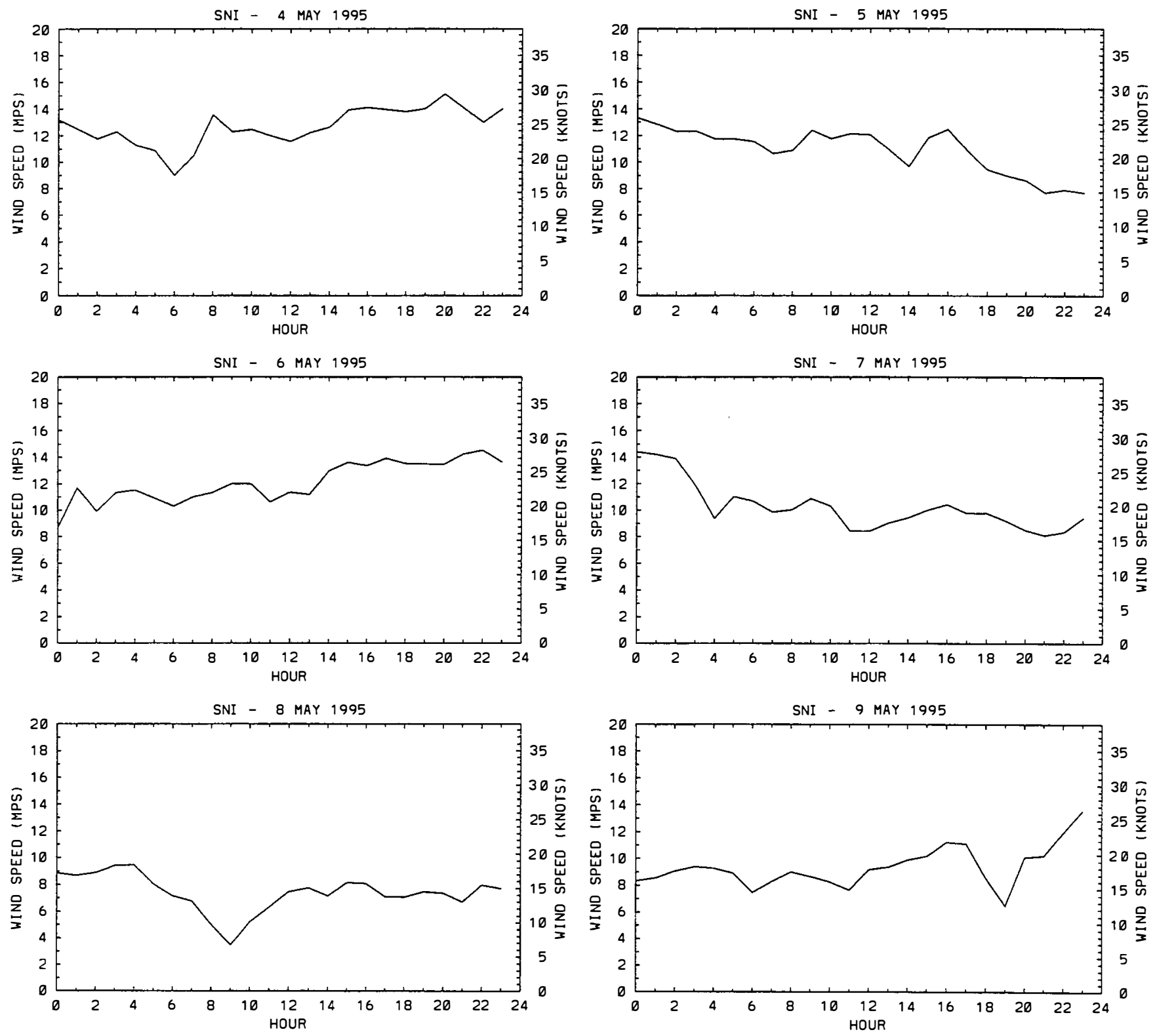

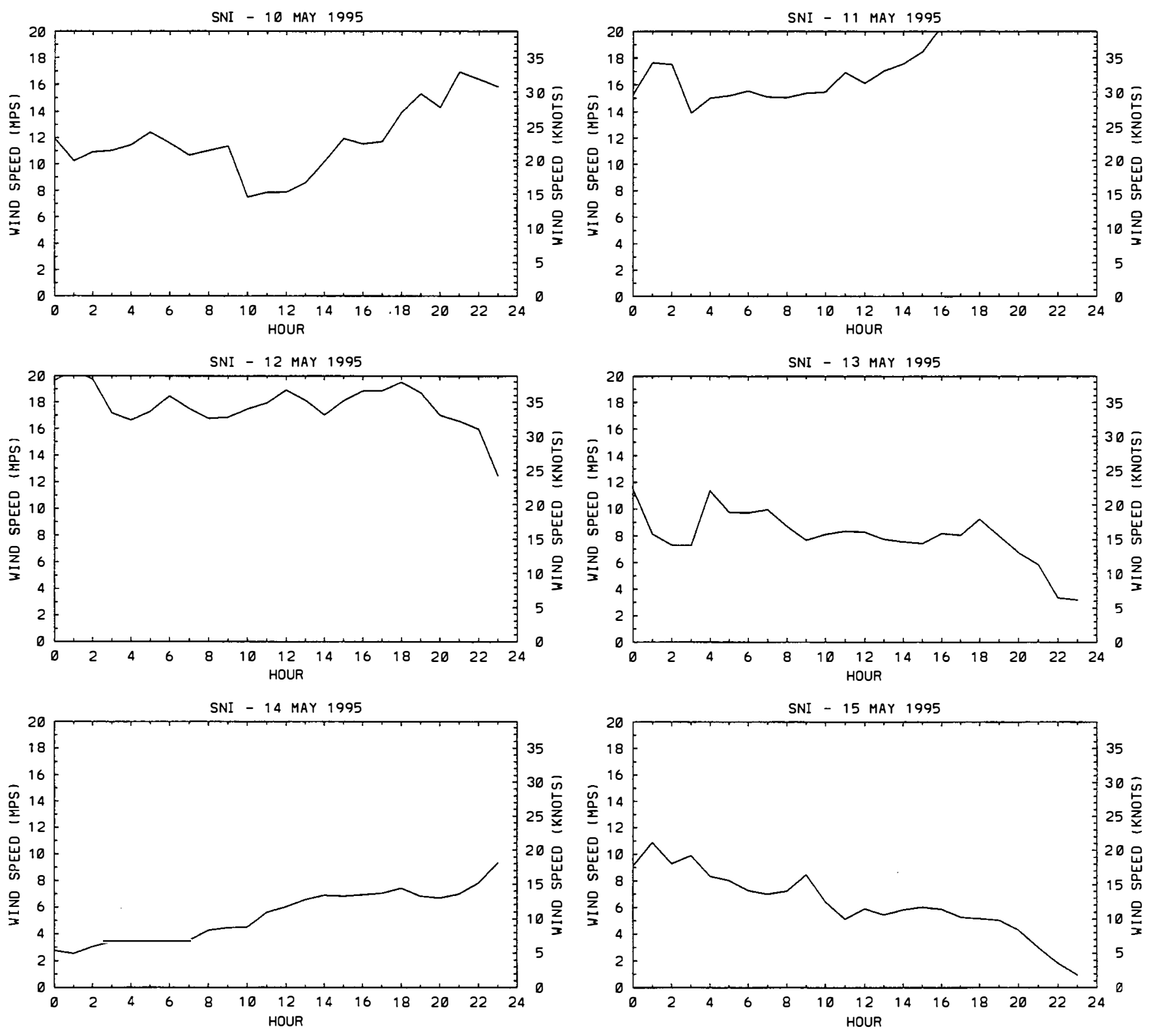

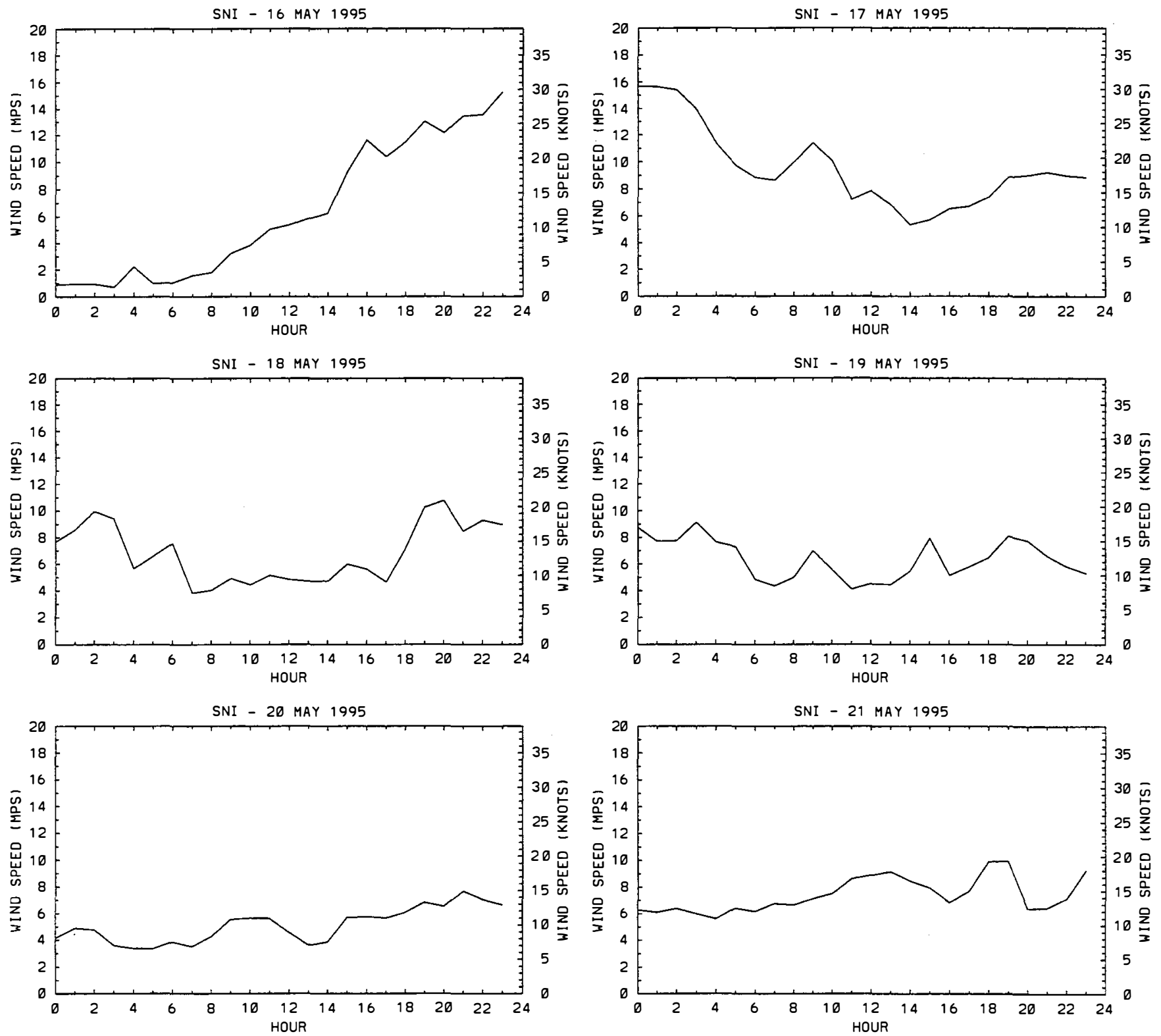

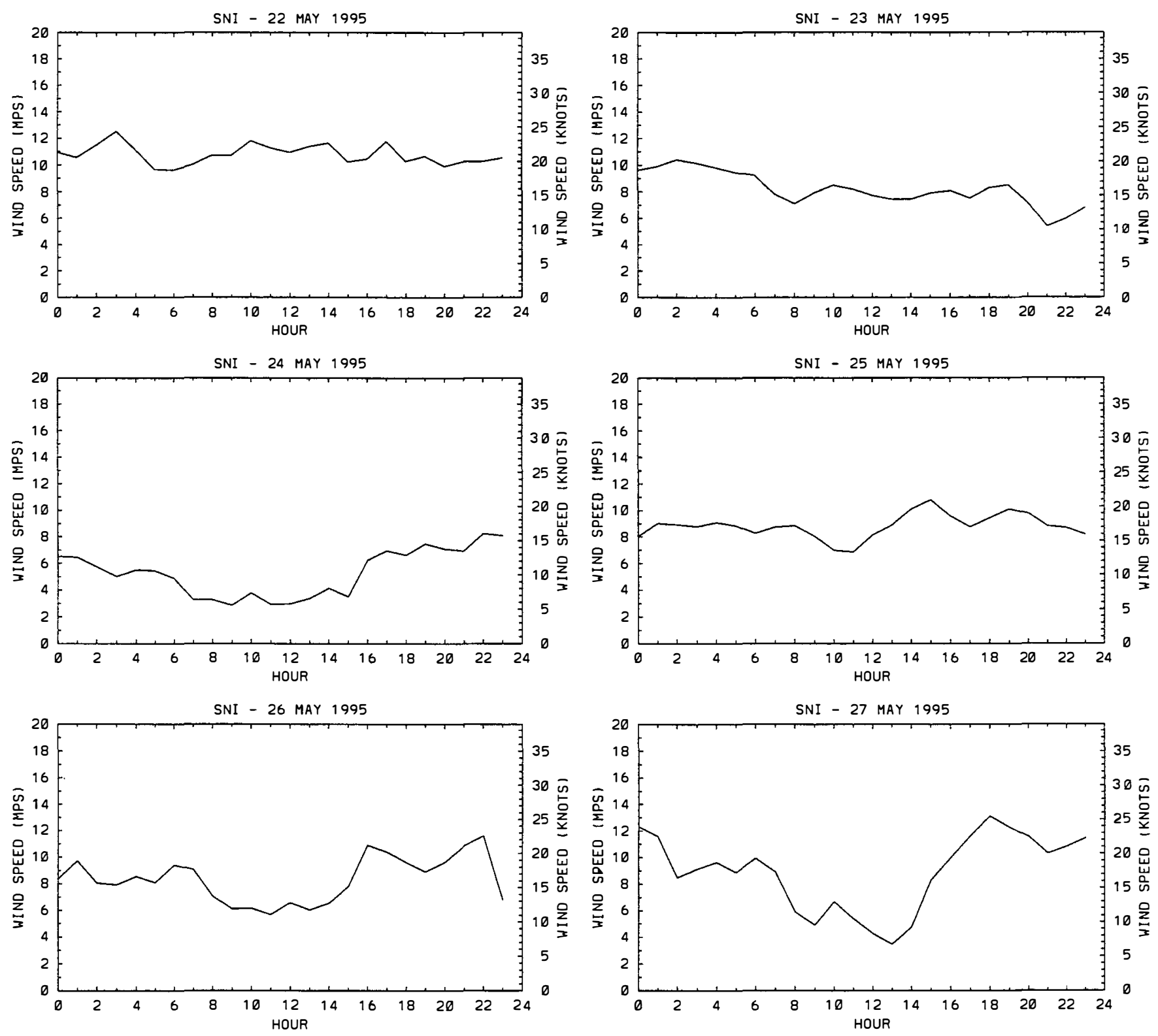

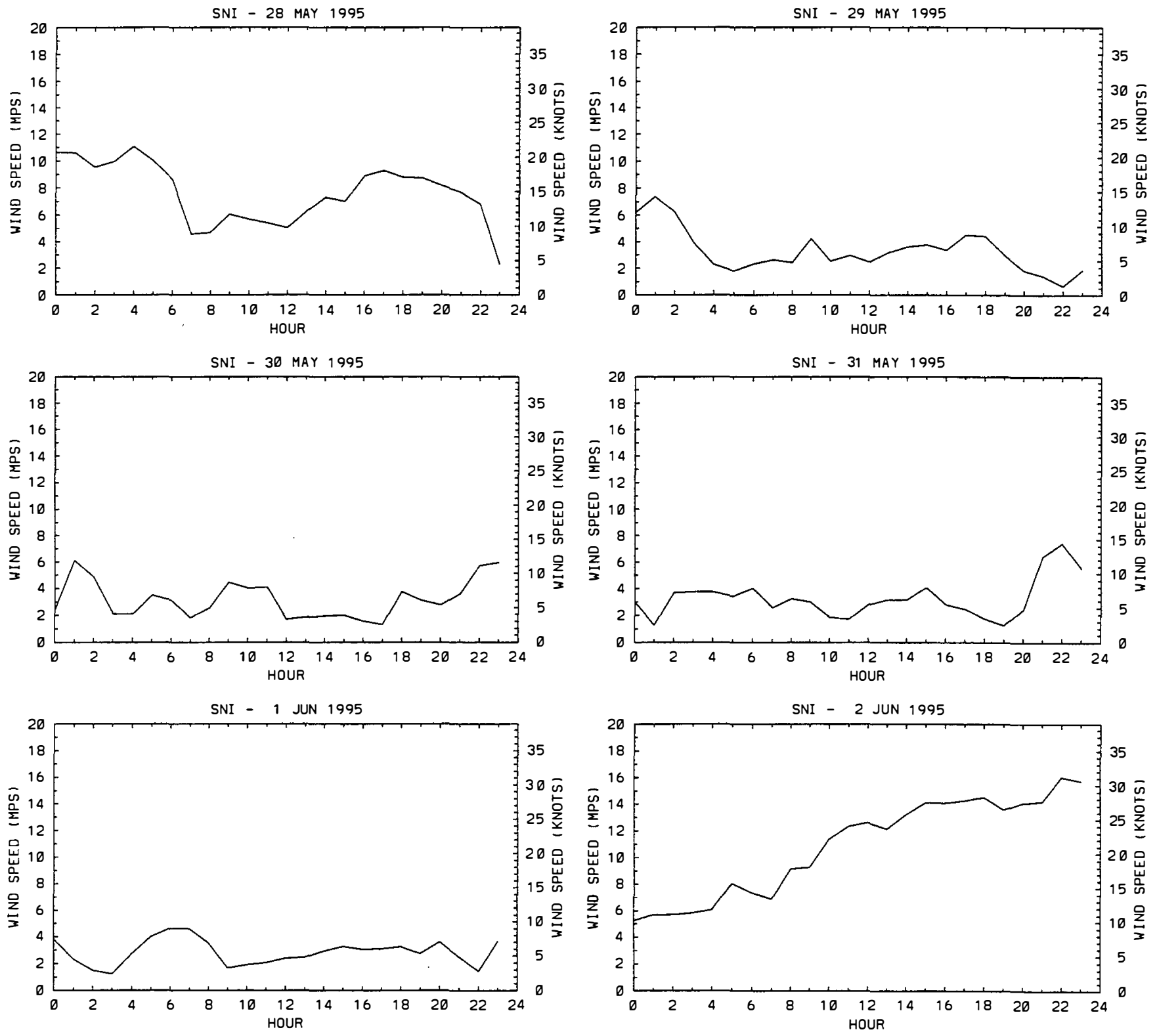

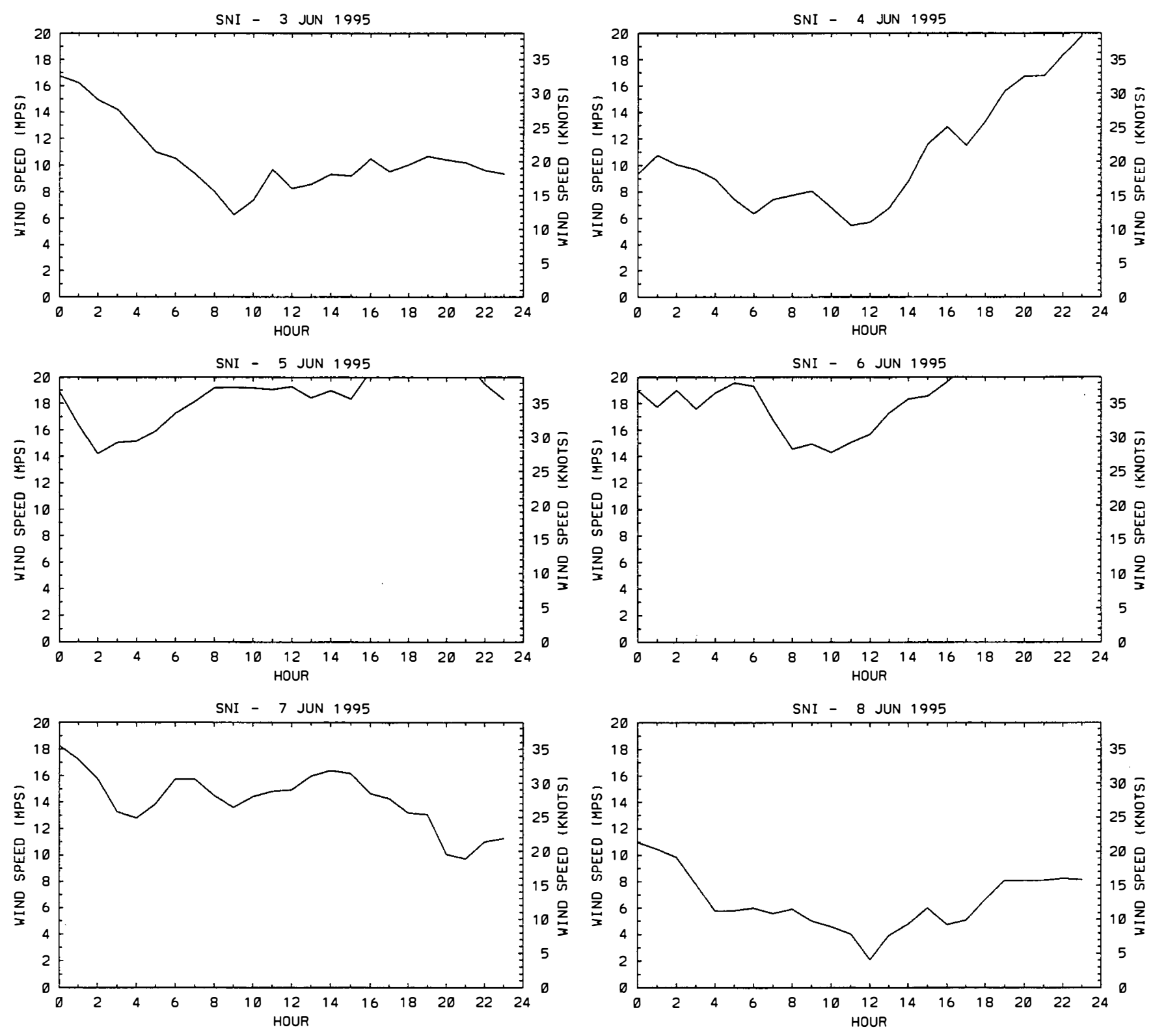

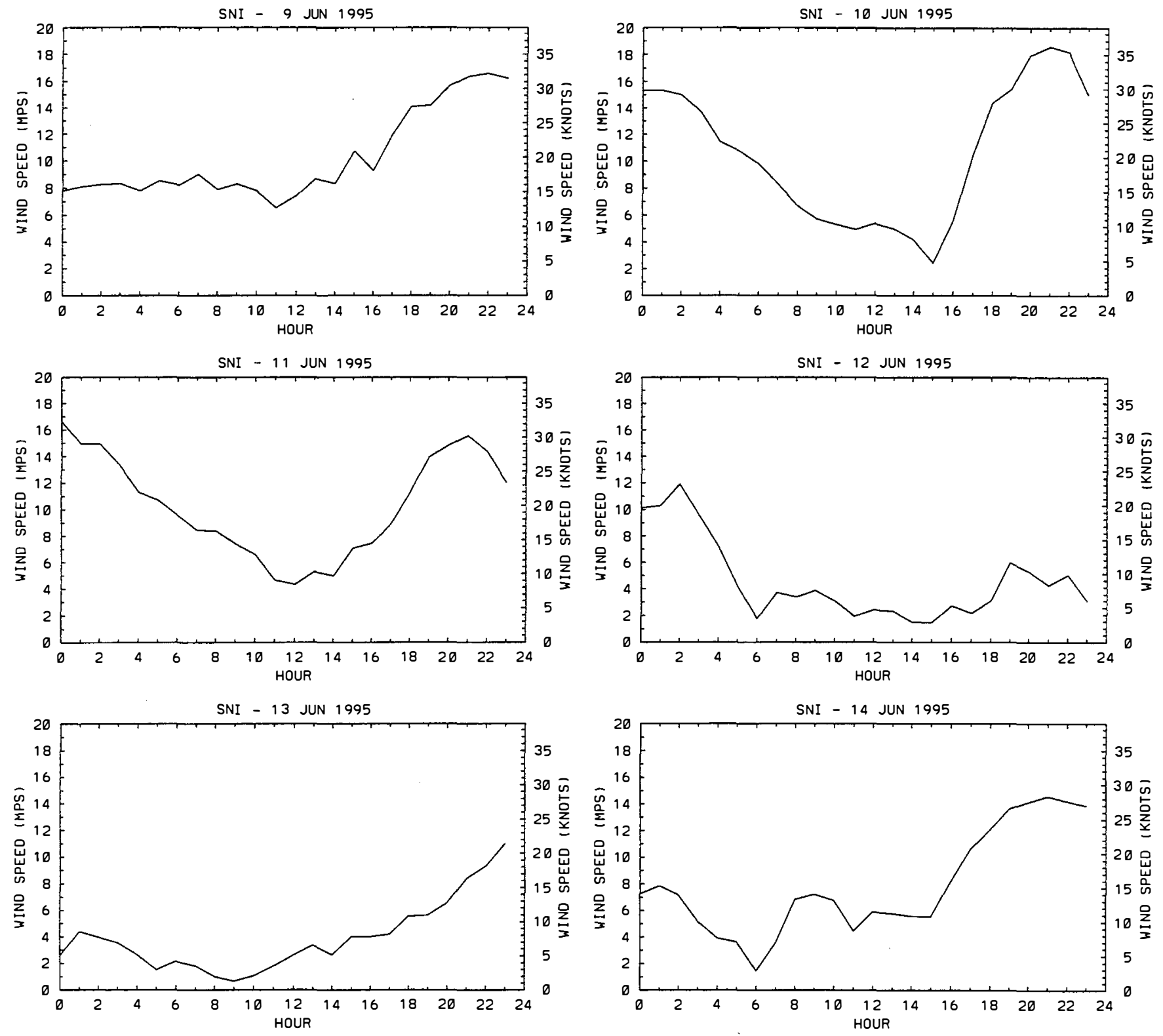

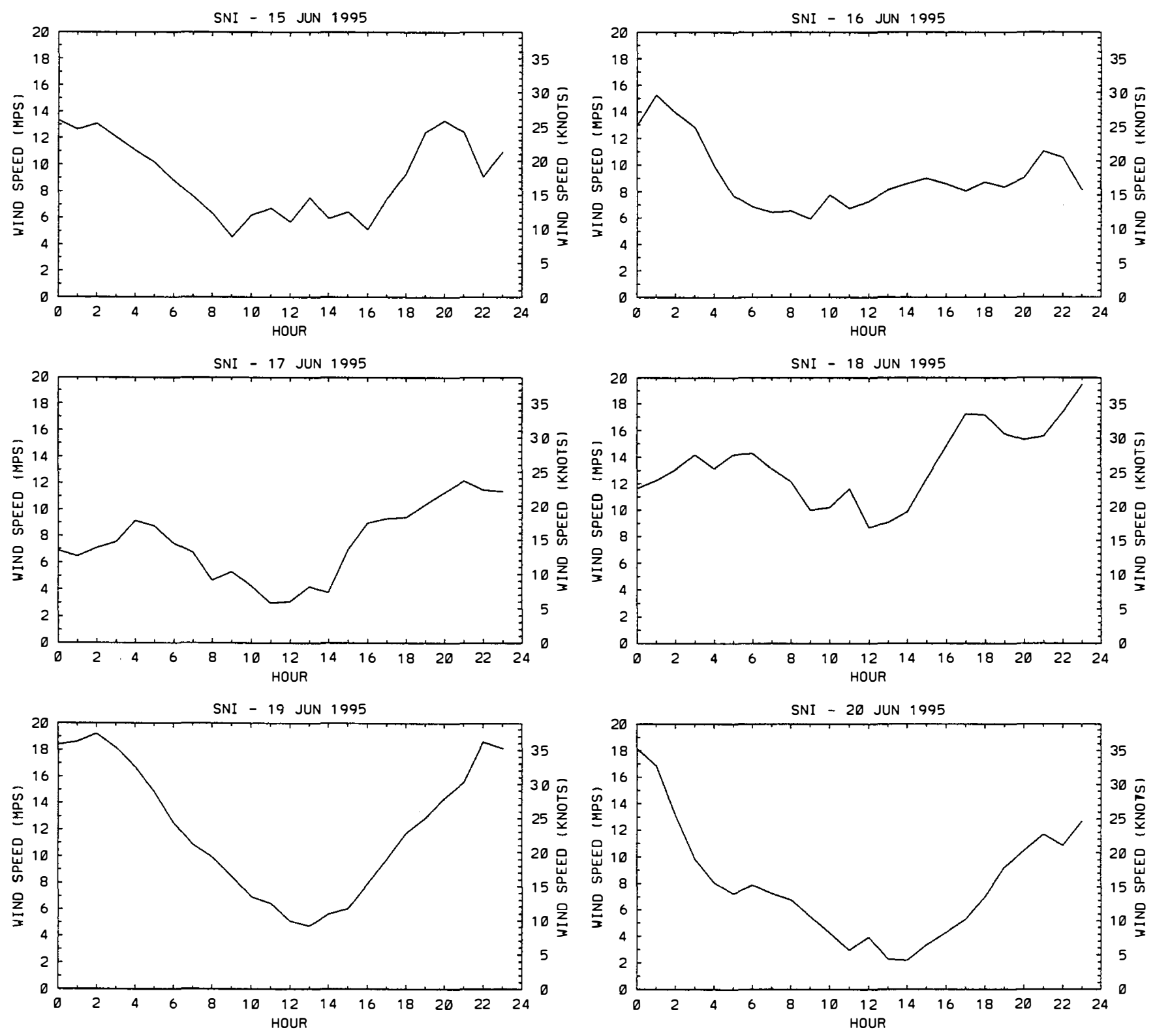

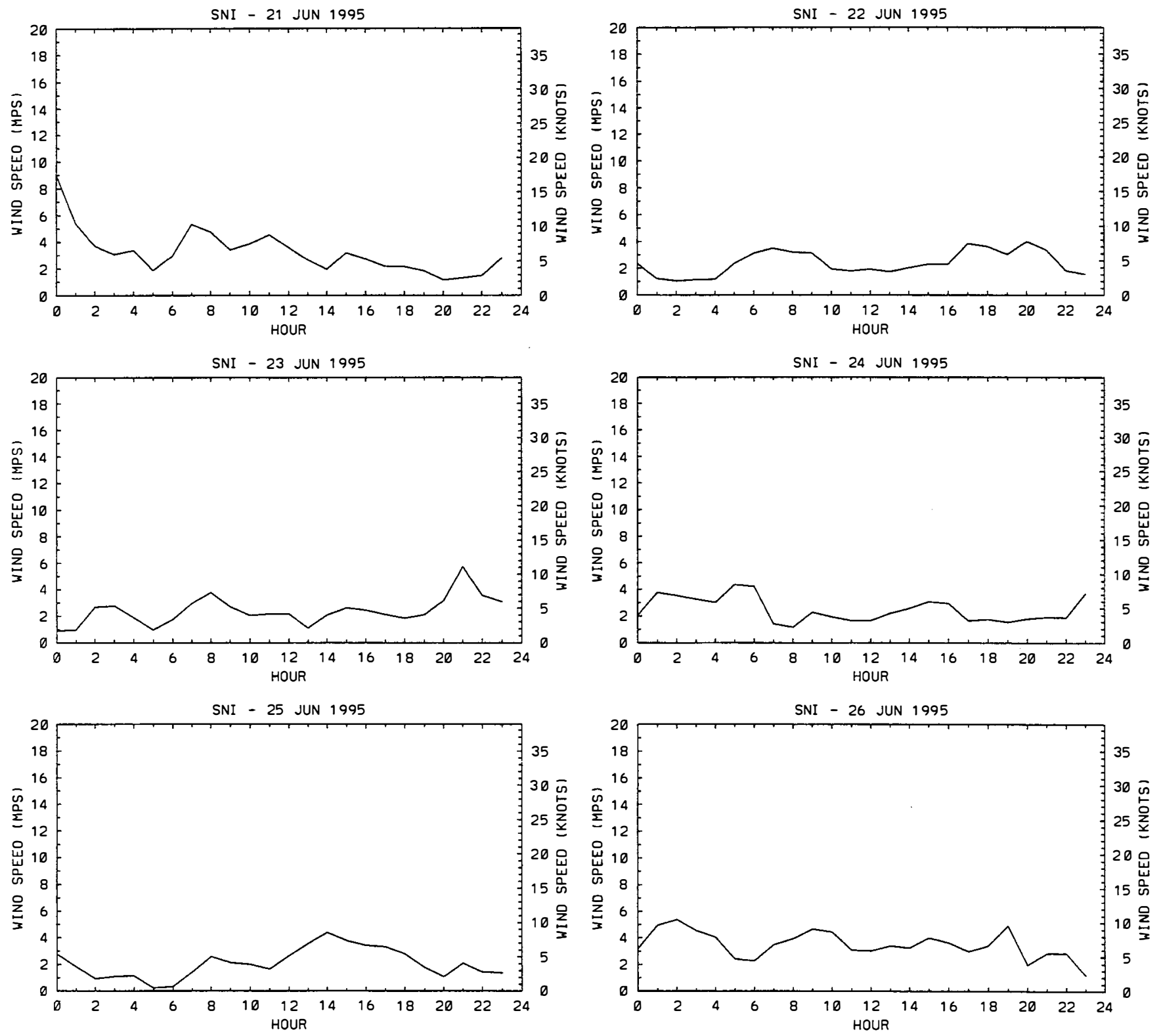

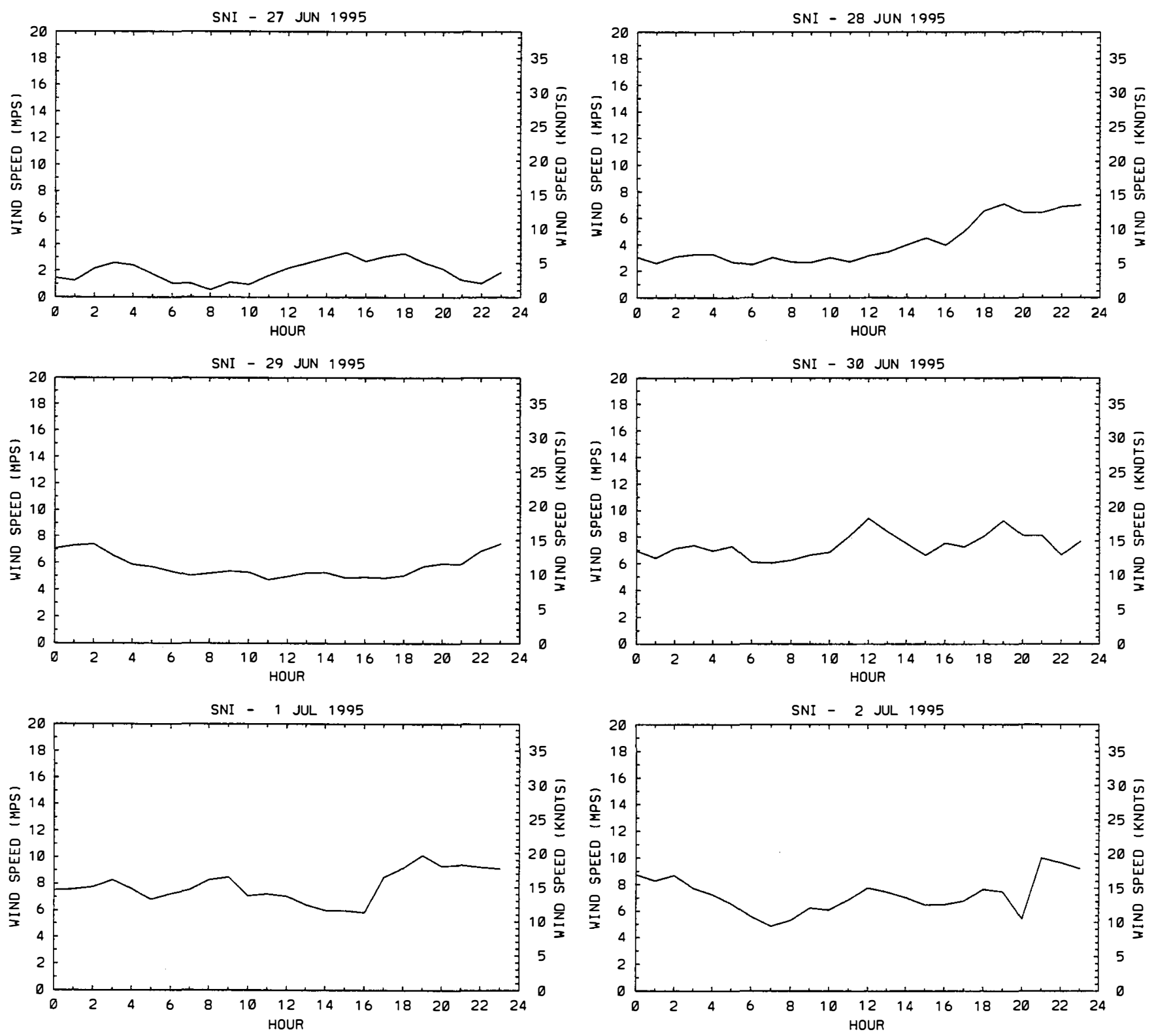

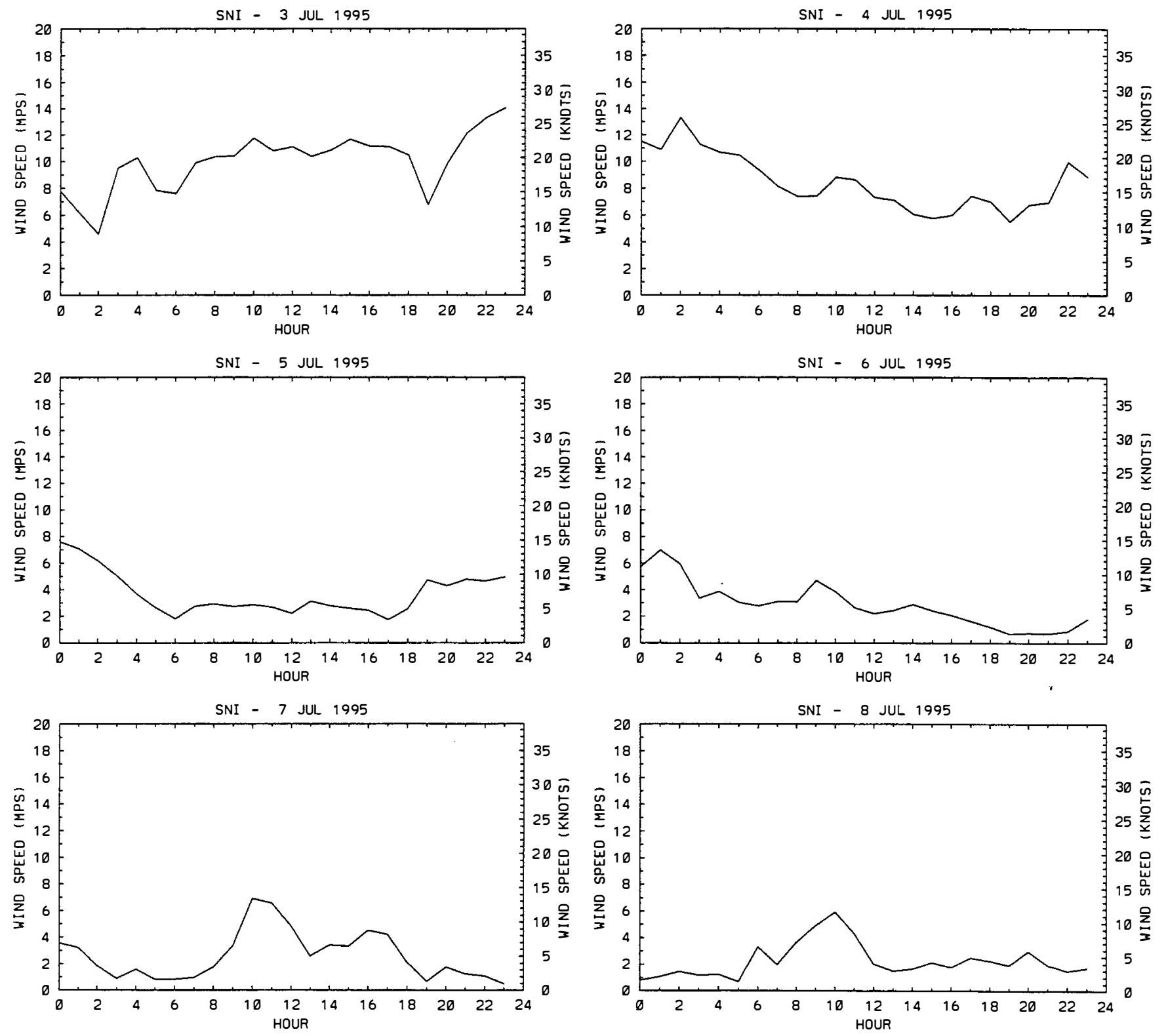

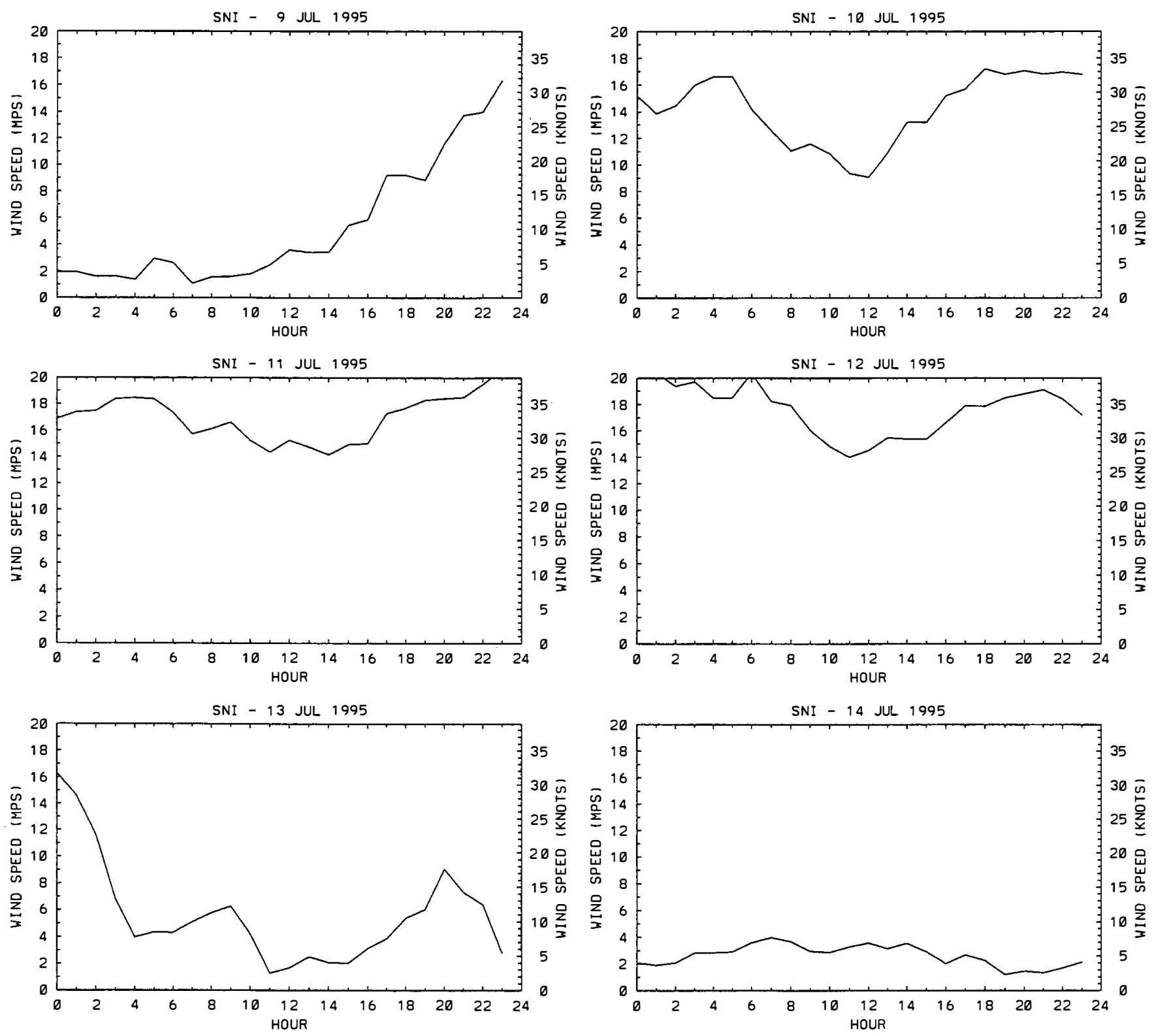

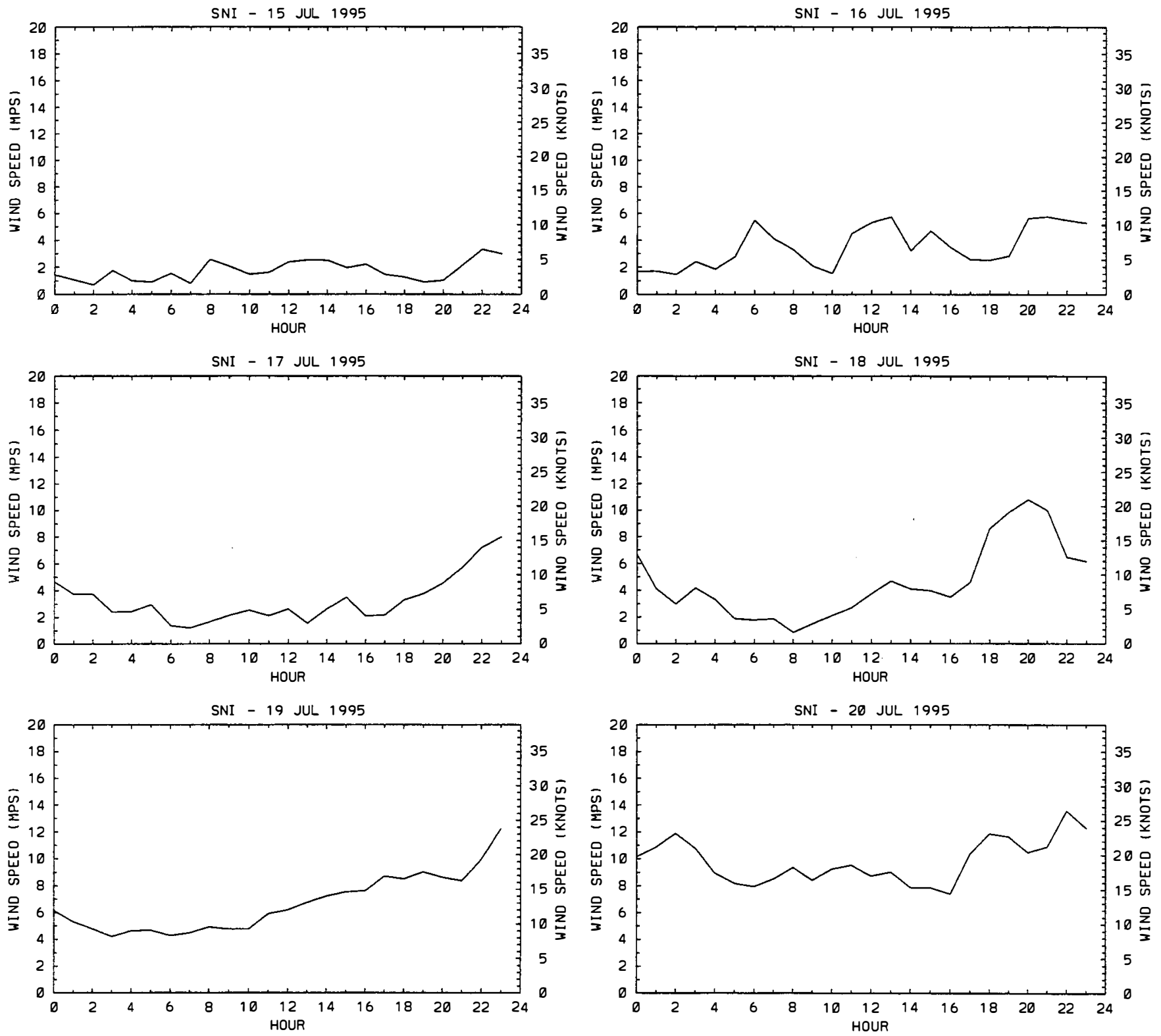

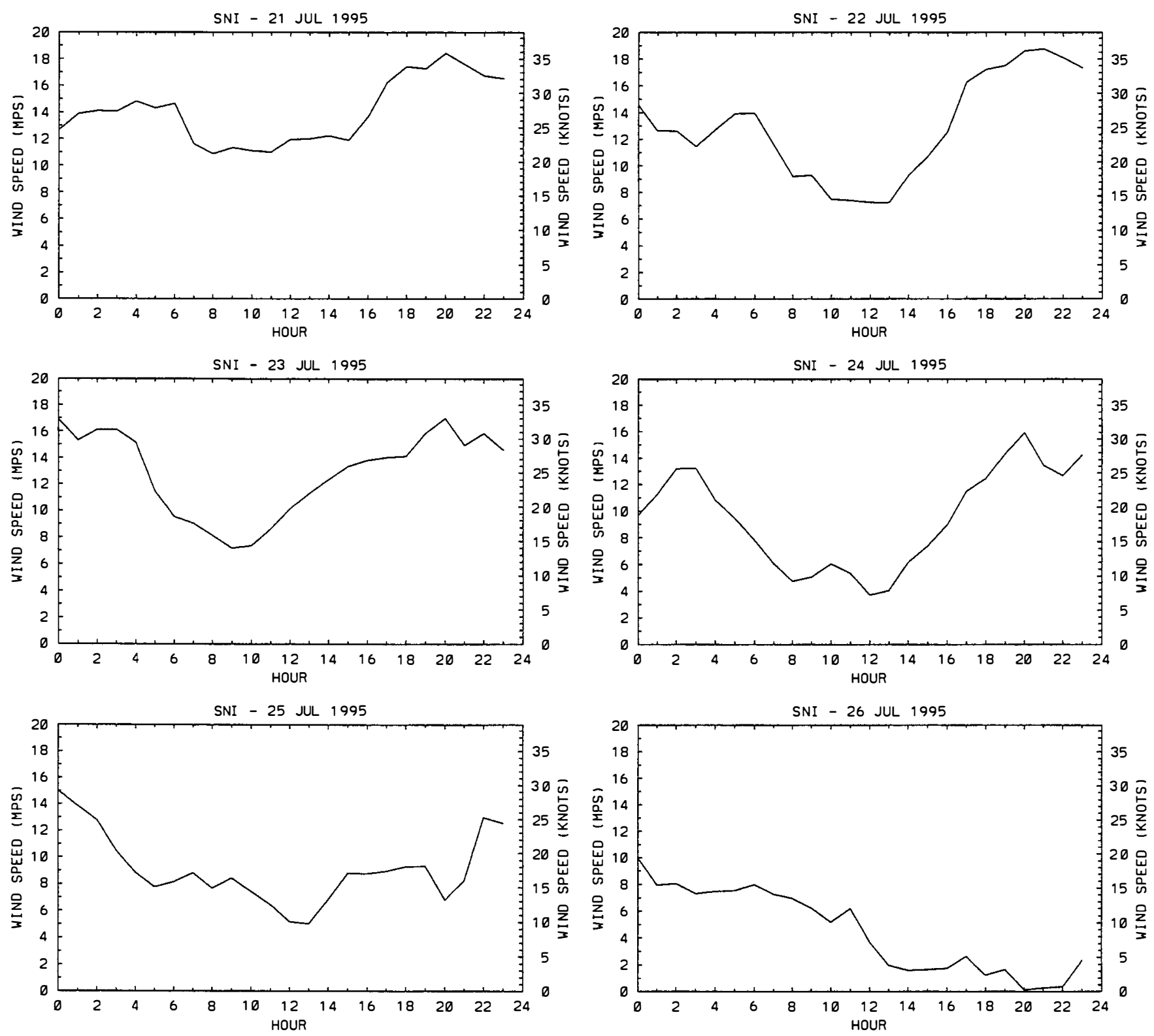

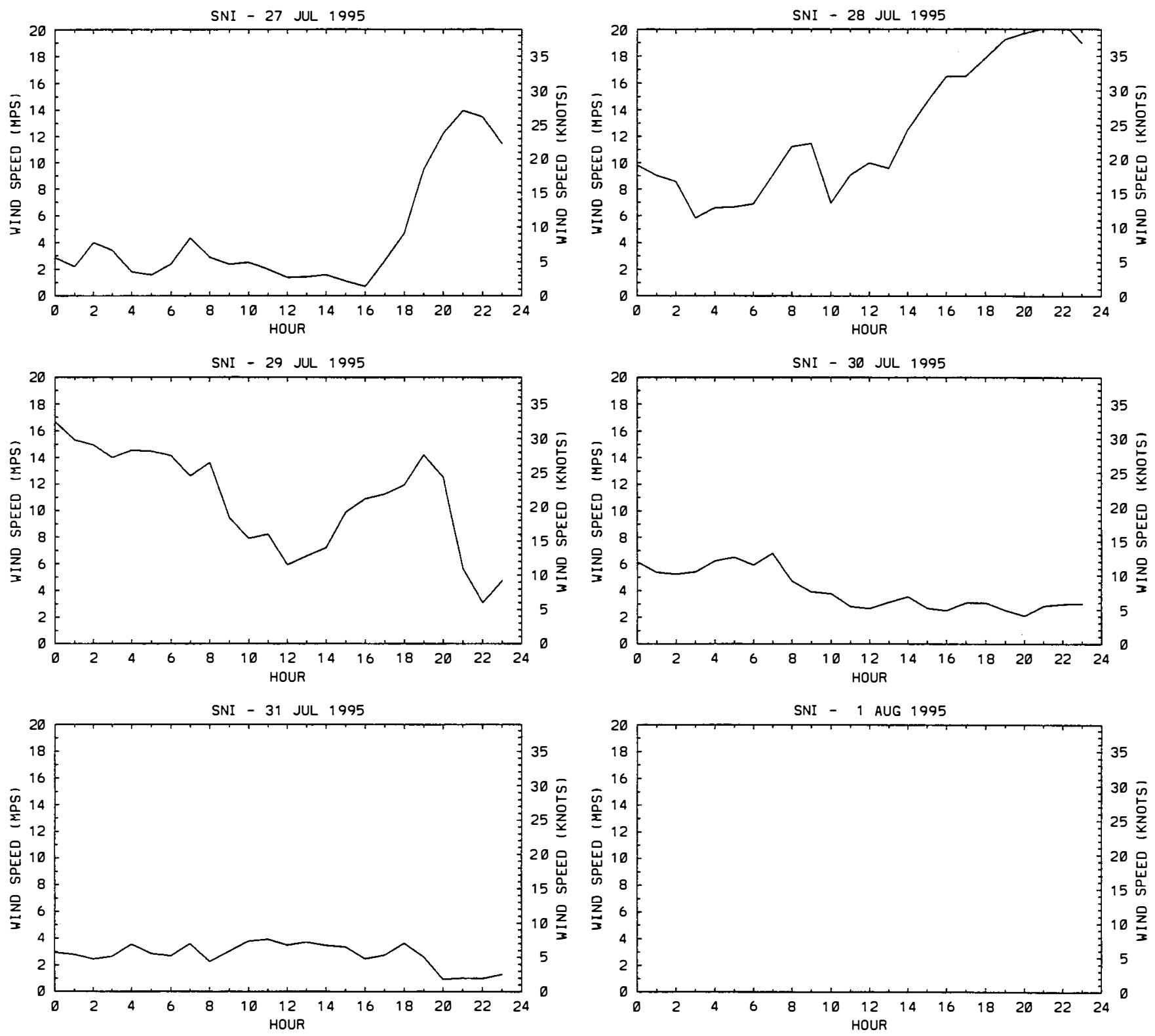
Repeat Figures for Days with Wind Speed Over 20 m/s 

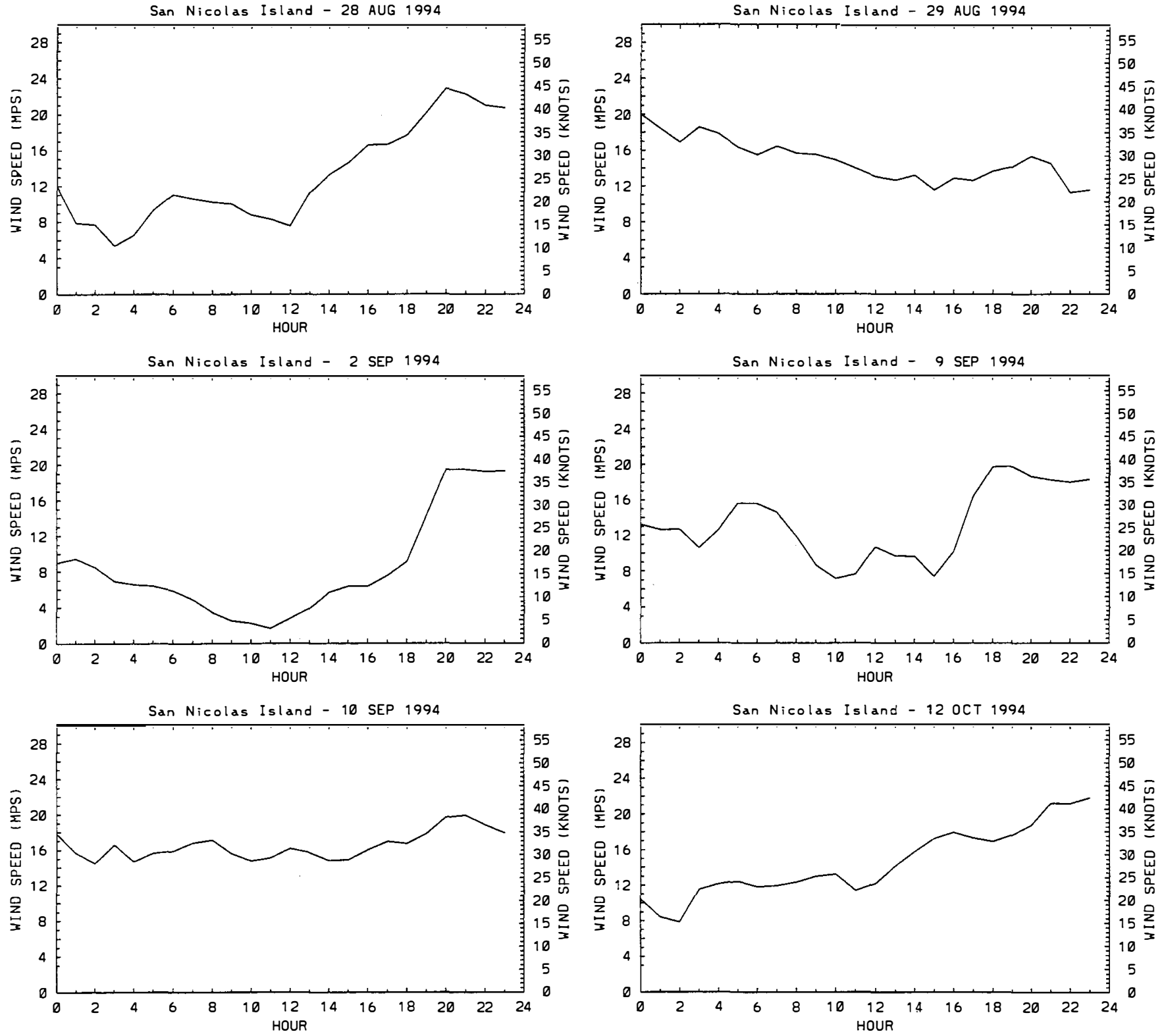

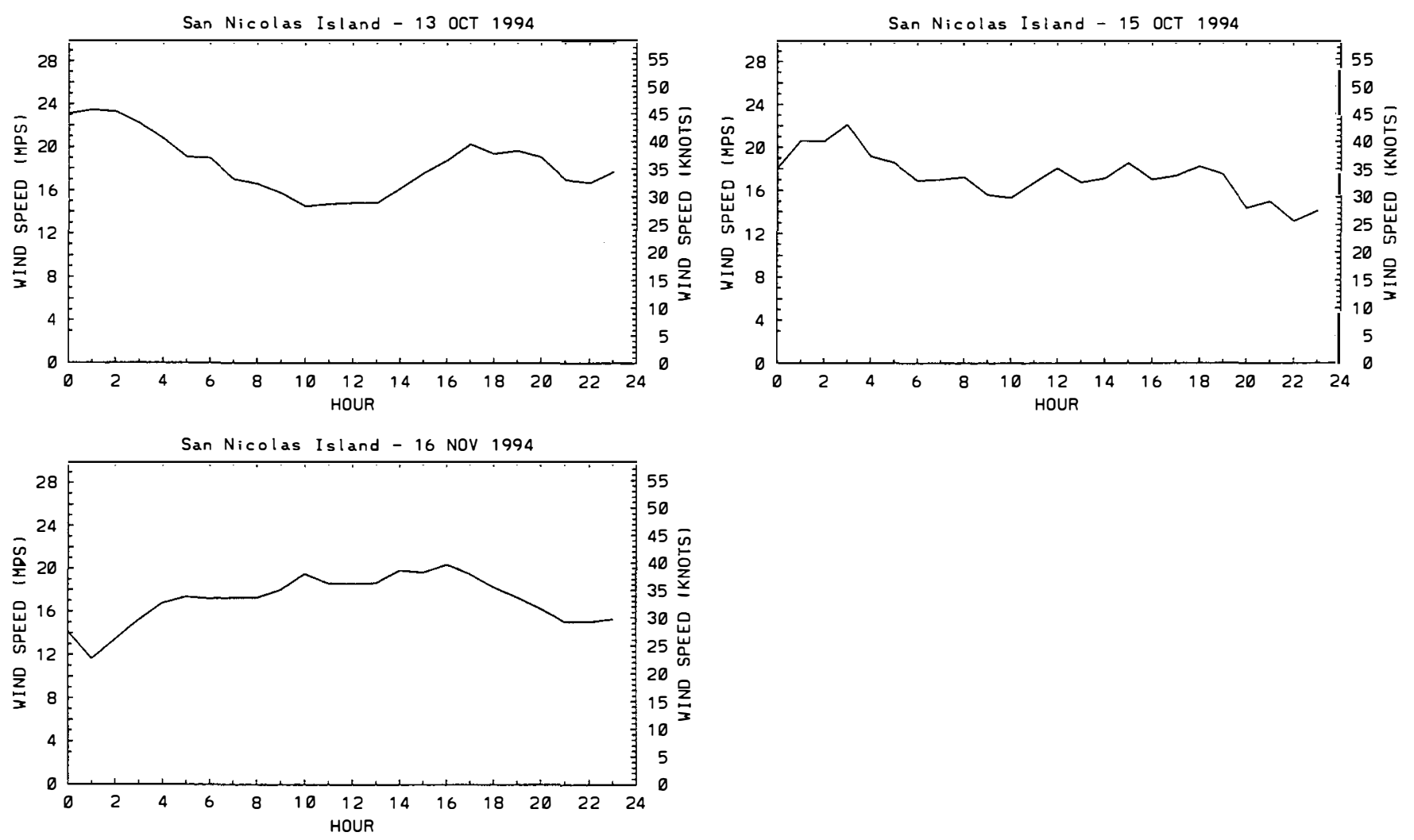

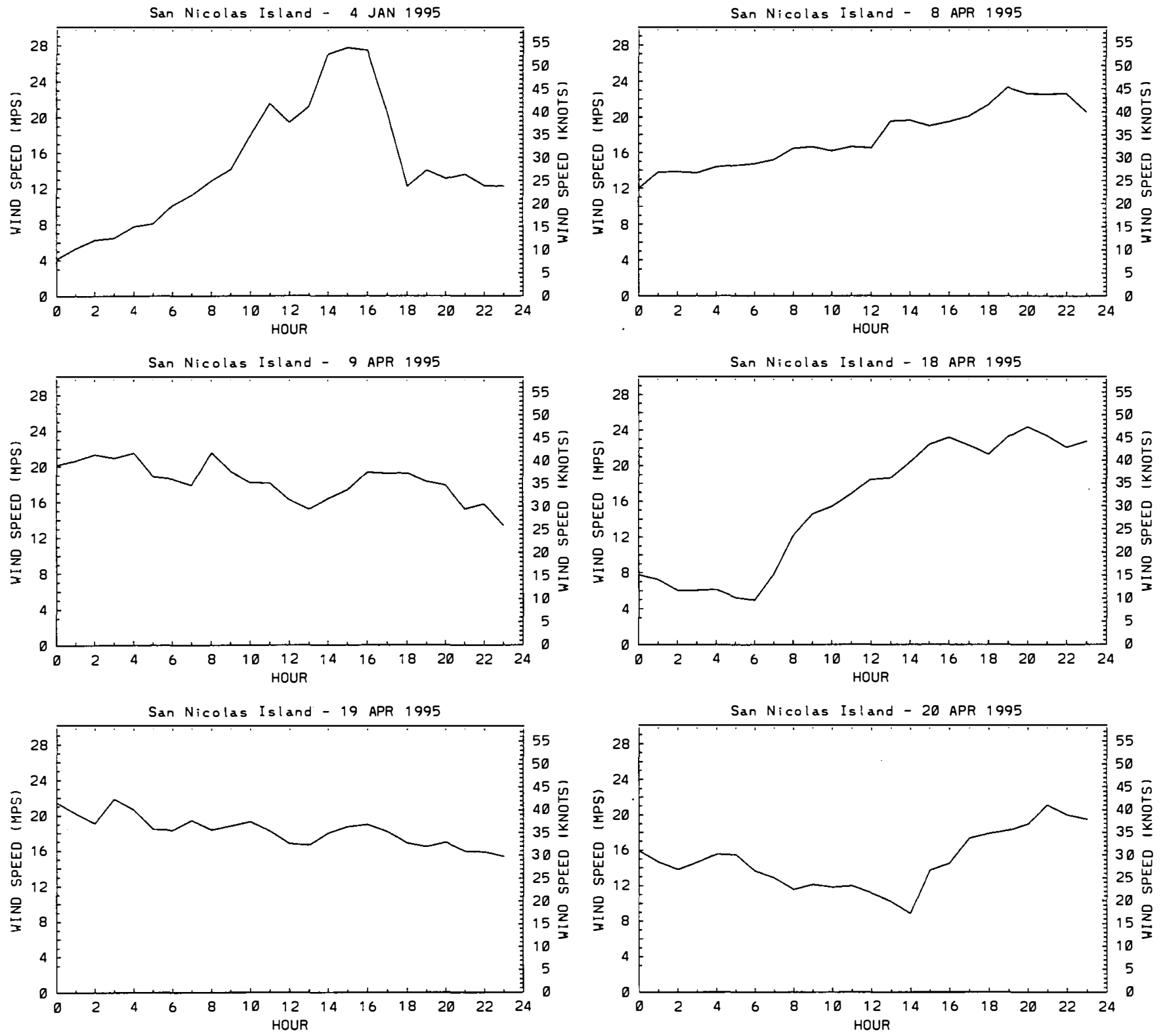

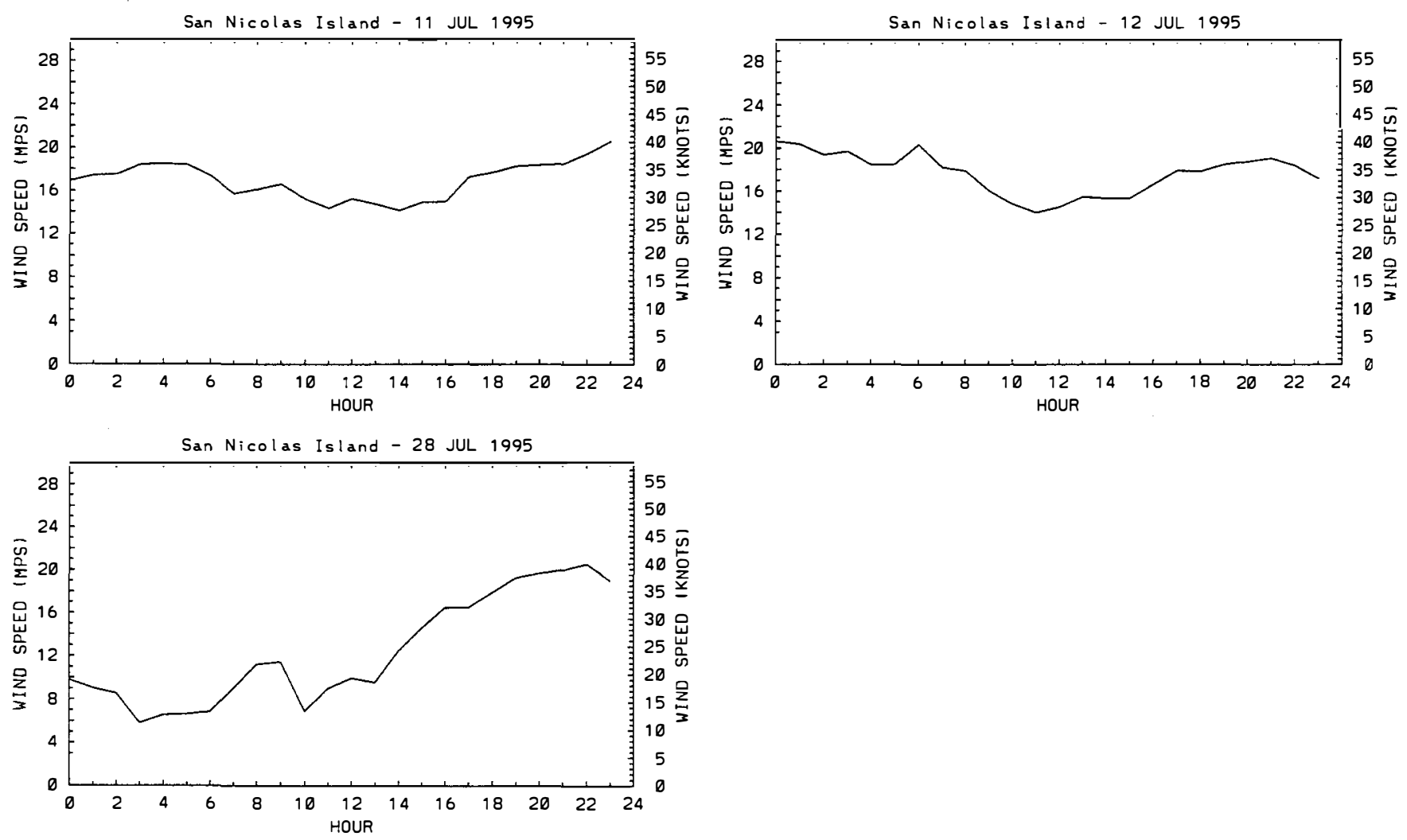
APPENDIX B: Monthly Wind Speed Records 


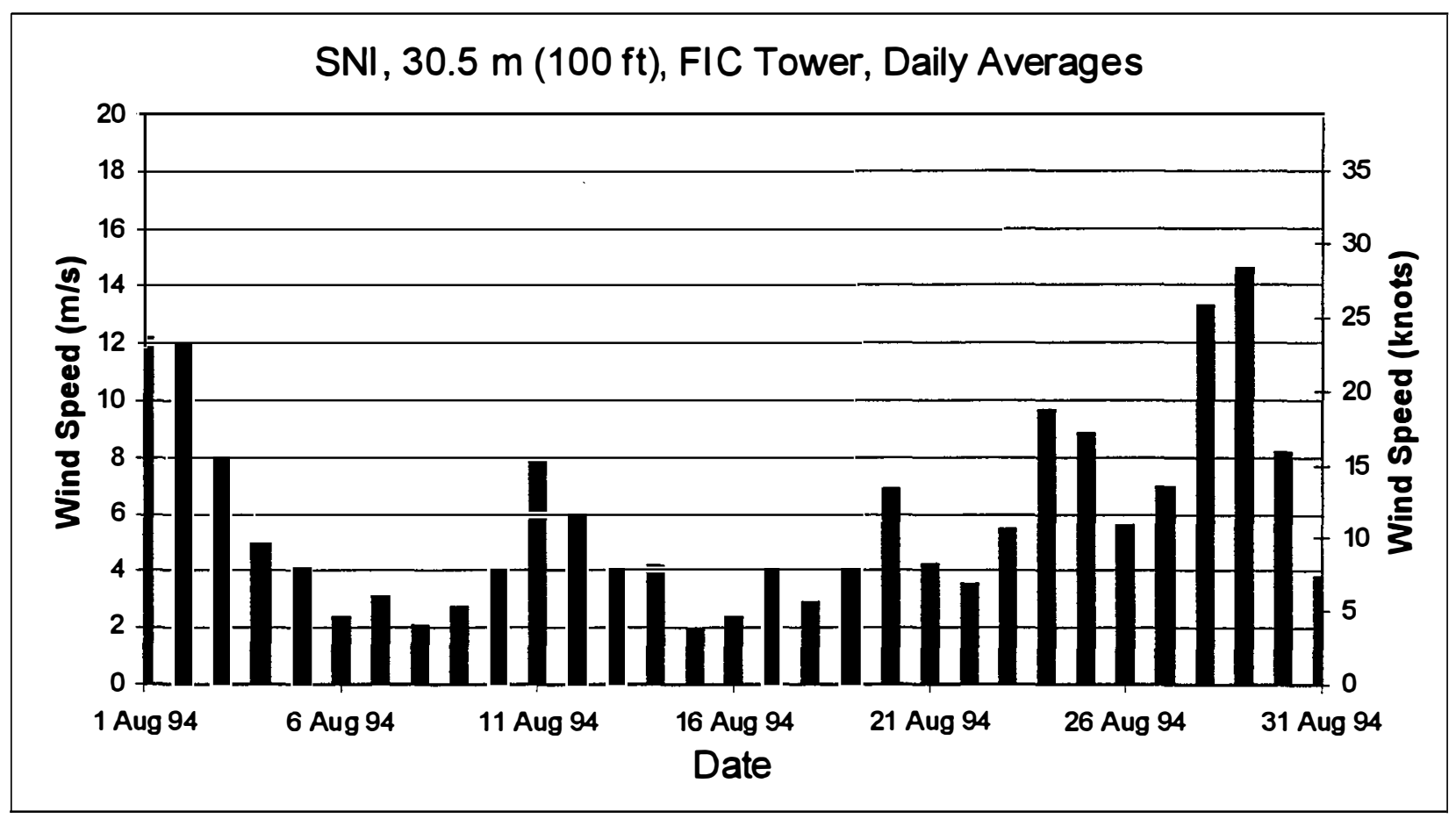

Figure B1： Wind Speed Record, August 1994

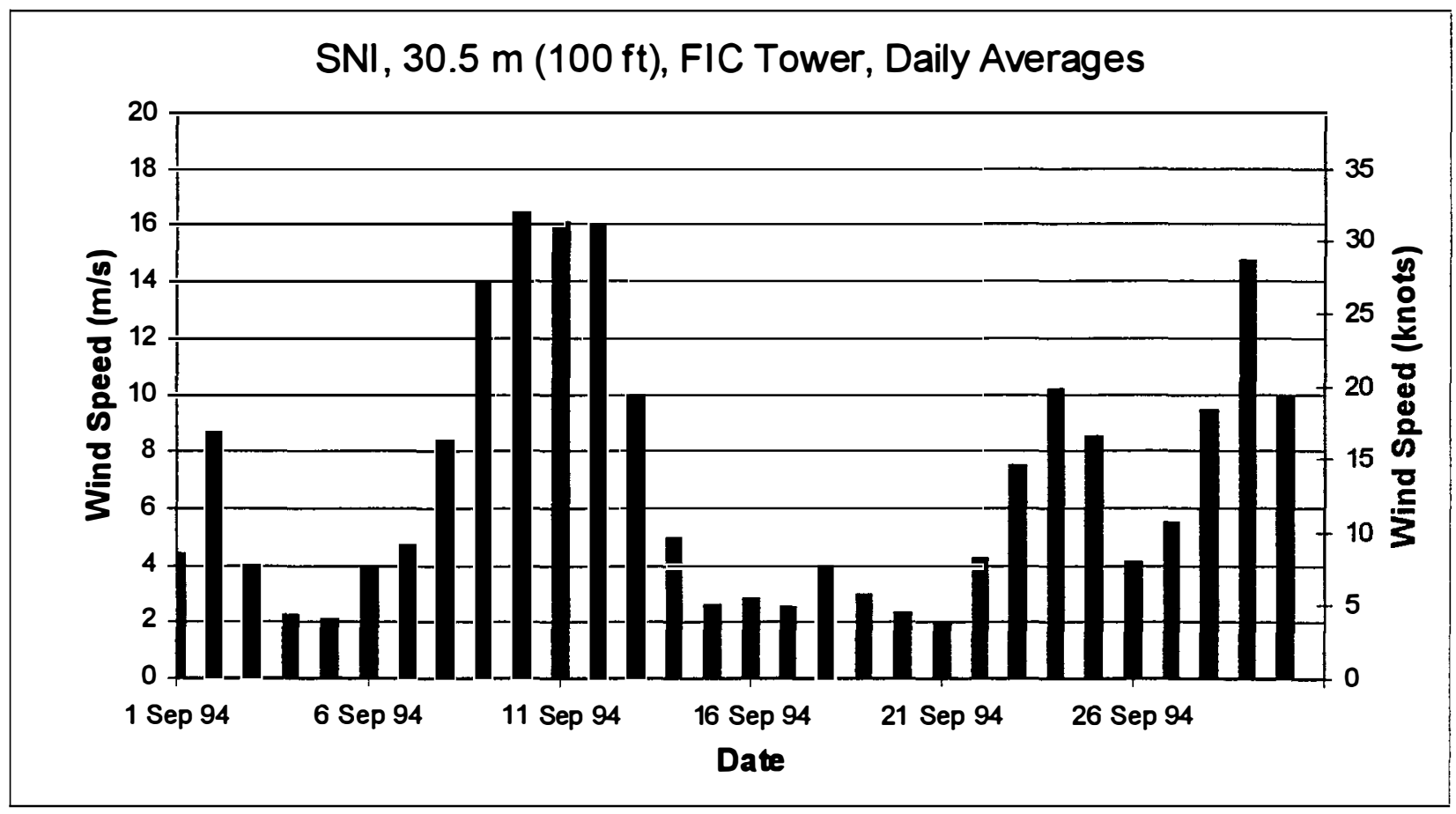

Figure B2: Wind Speed Record, September 1994 


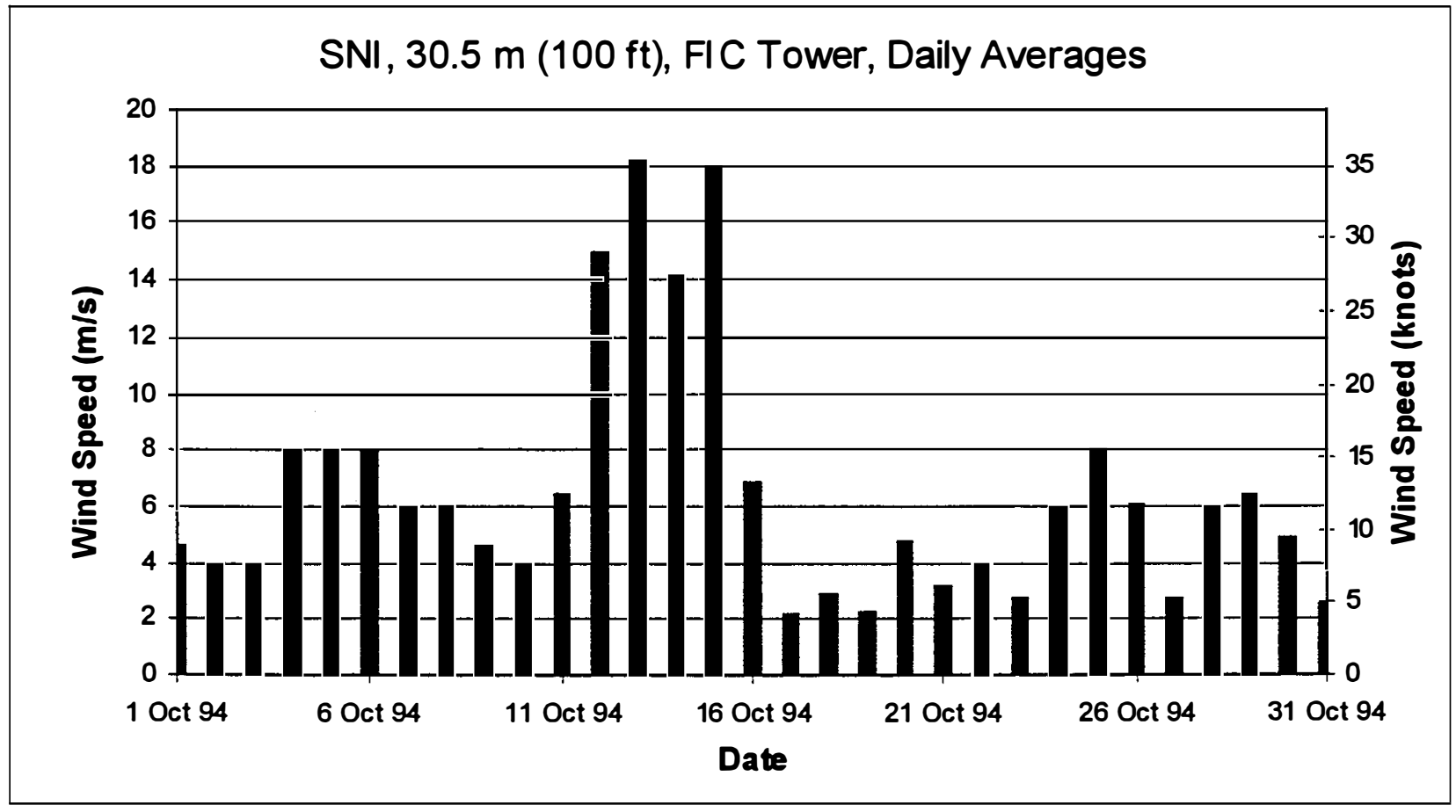

Figure B3: Wind Speed Record, October 1994

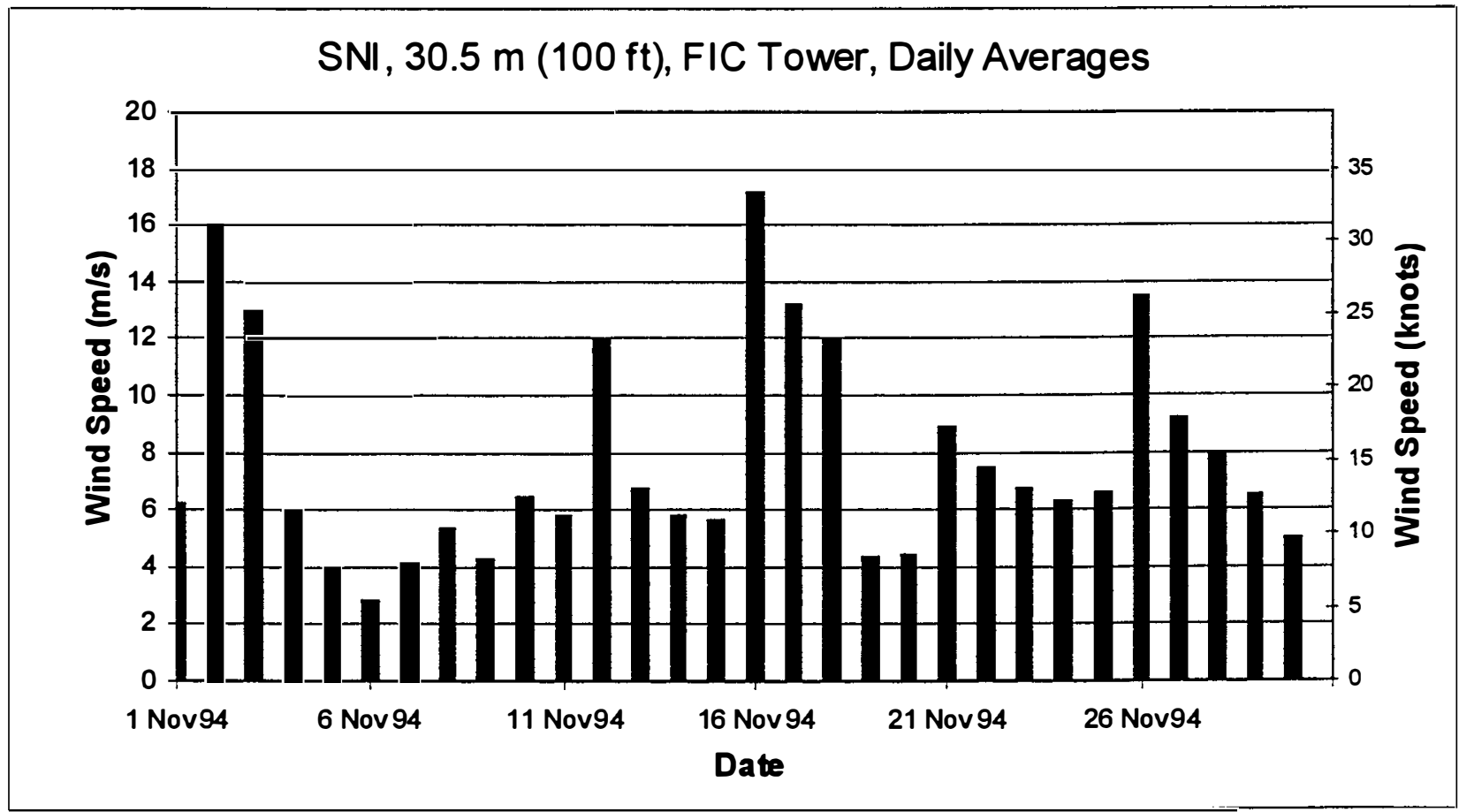

Figure B4: Wind Speed Record, November 1994 


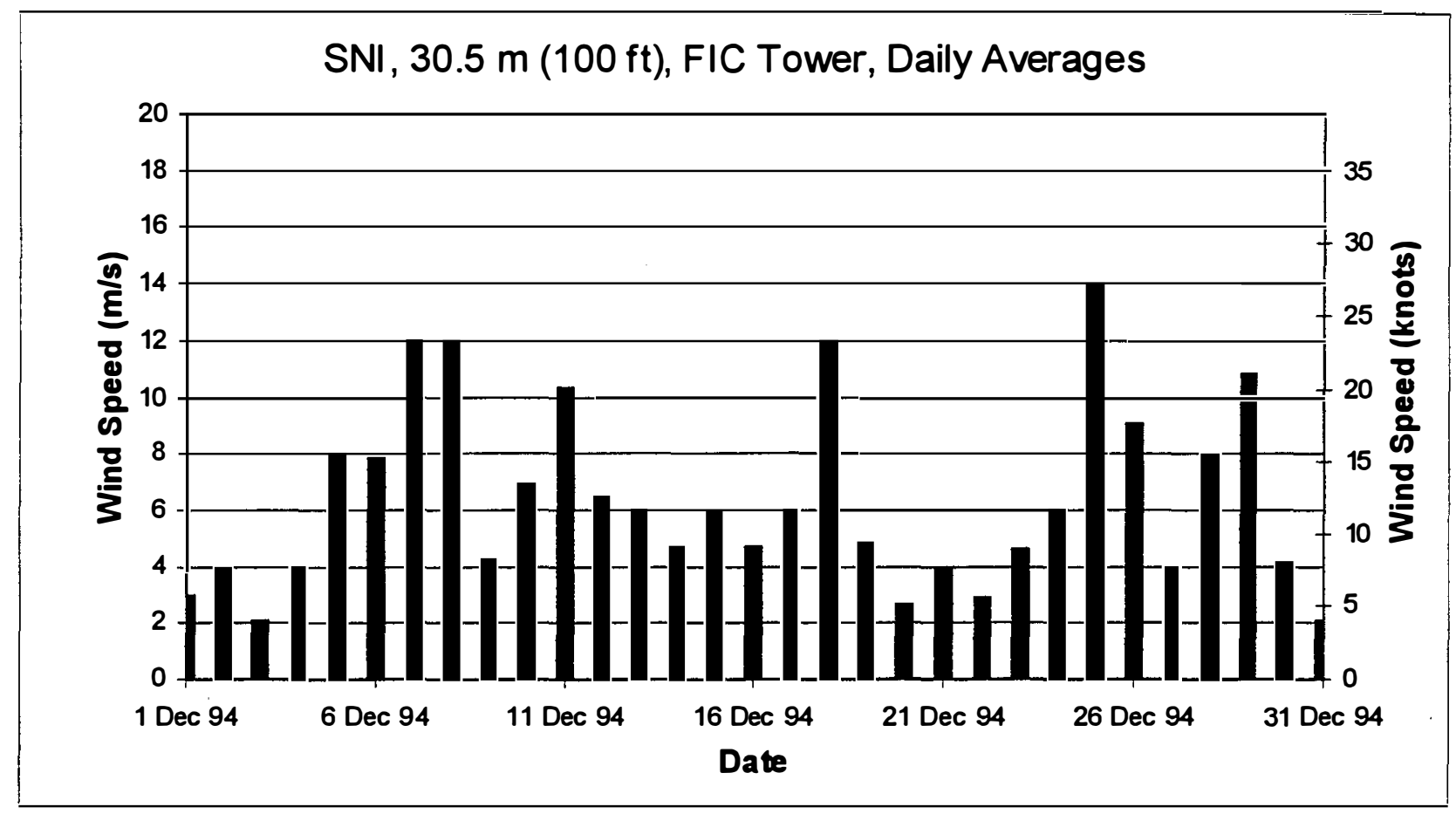

Figure B5: Wind Speed Record, December 1994

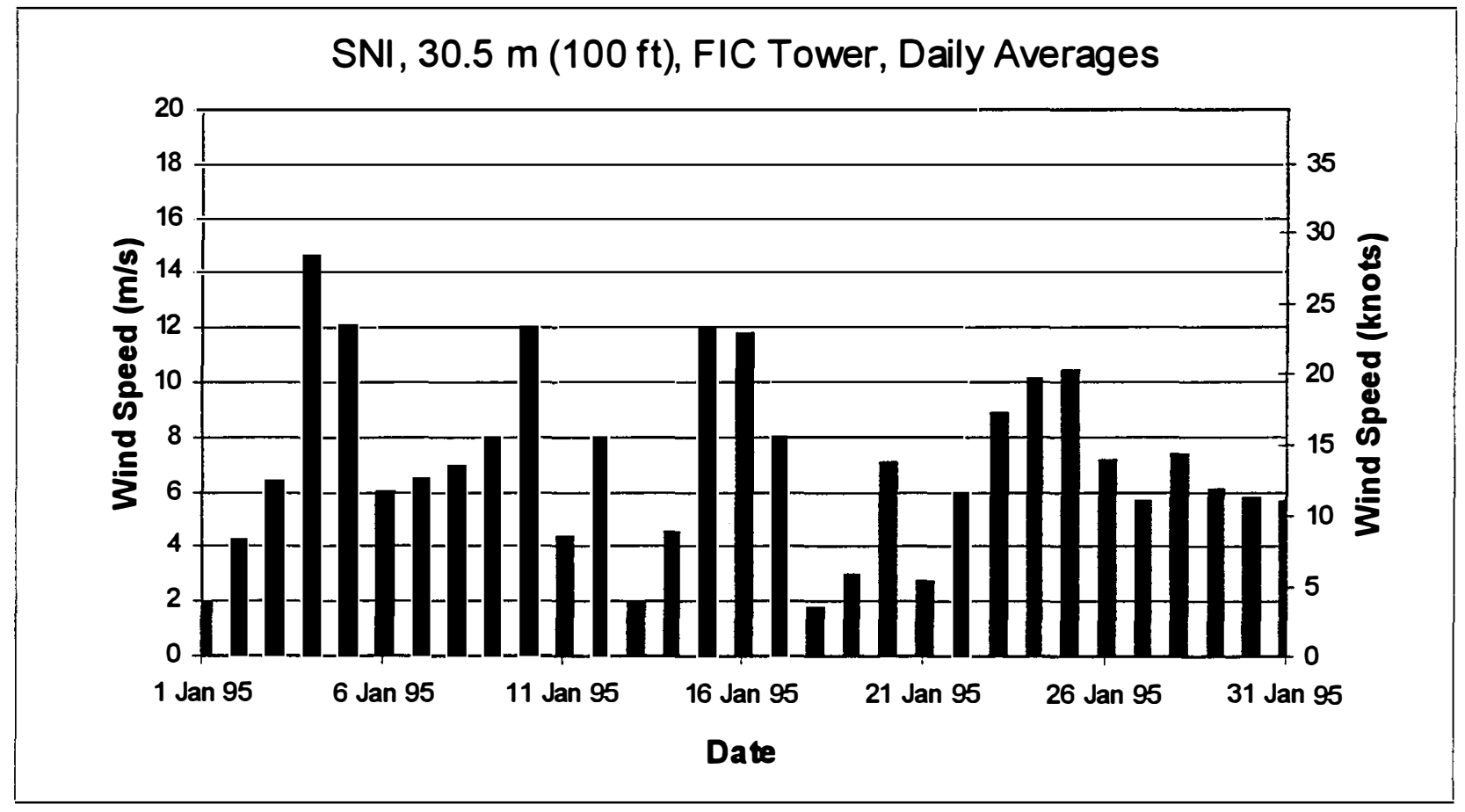

Figure B6: Wind Speed Record, January 1995 


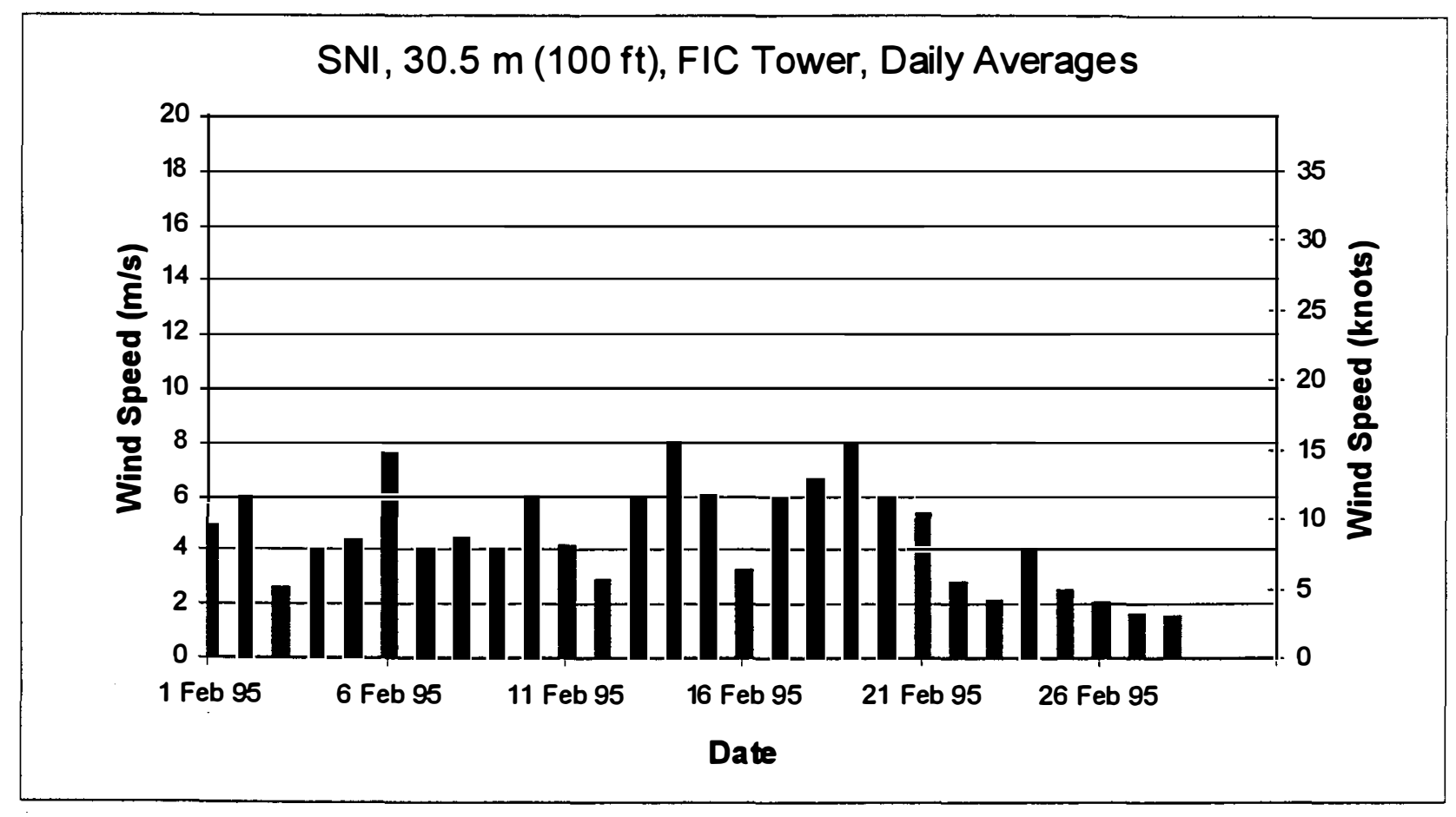

Figure B7: Wind Speed Record, February 1995

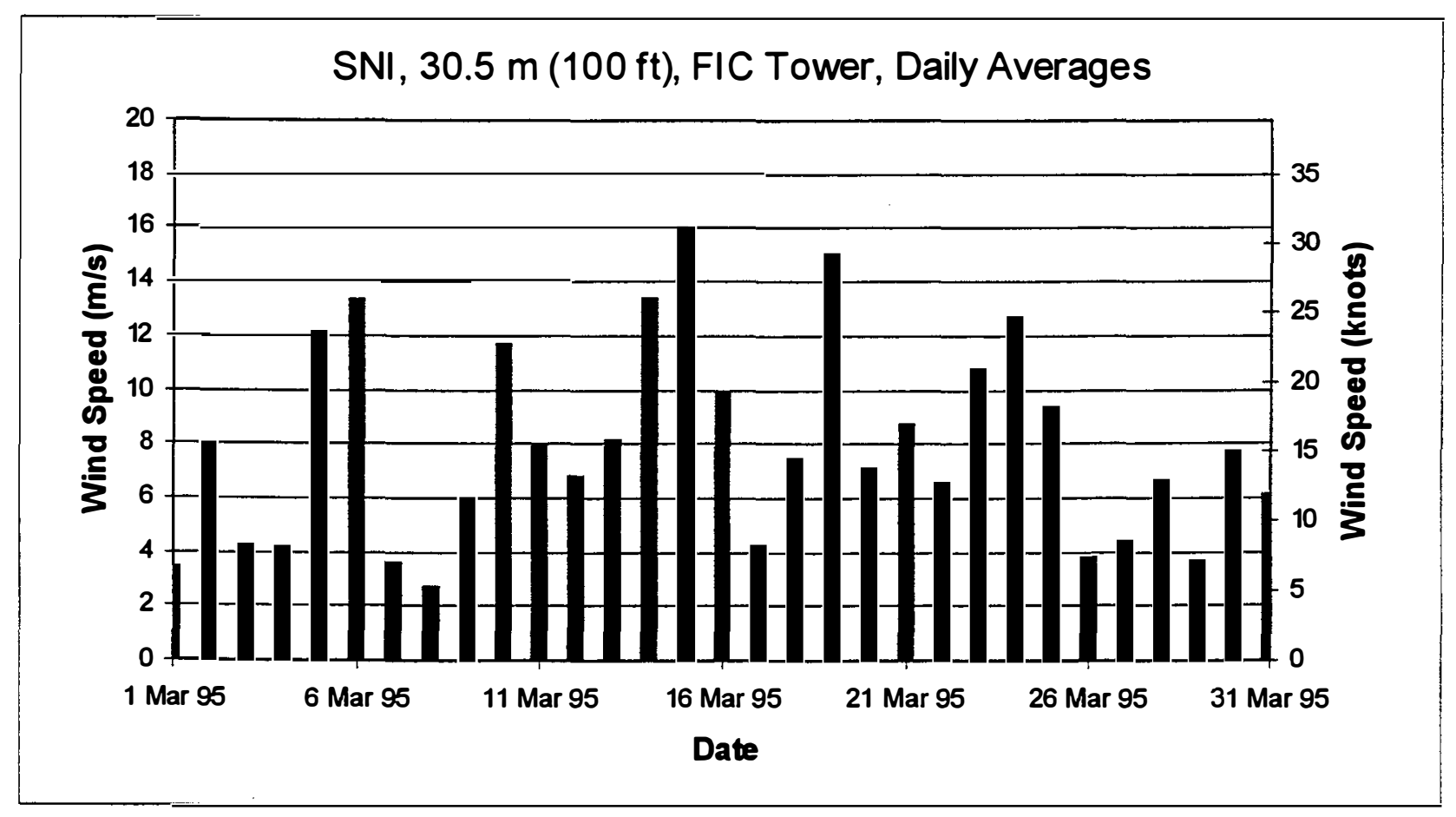

Figure B8: Wind Speed Record, March 1995 


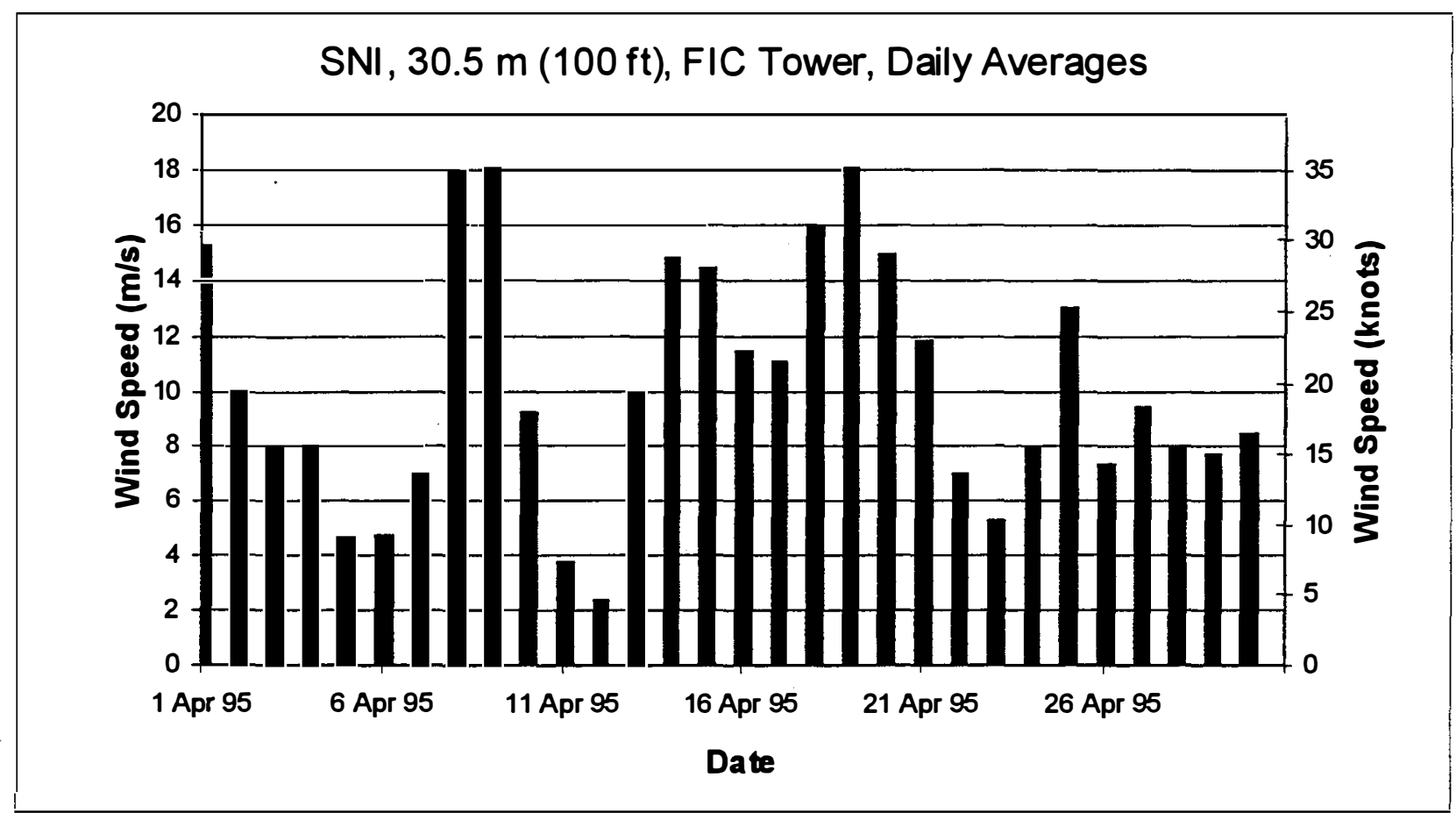

Figure B9: Wind Speed Record, April 1995

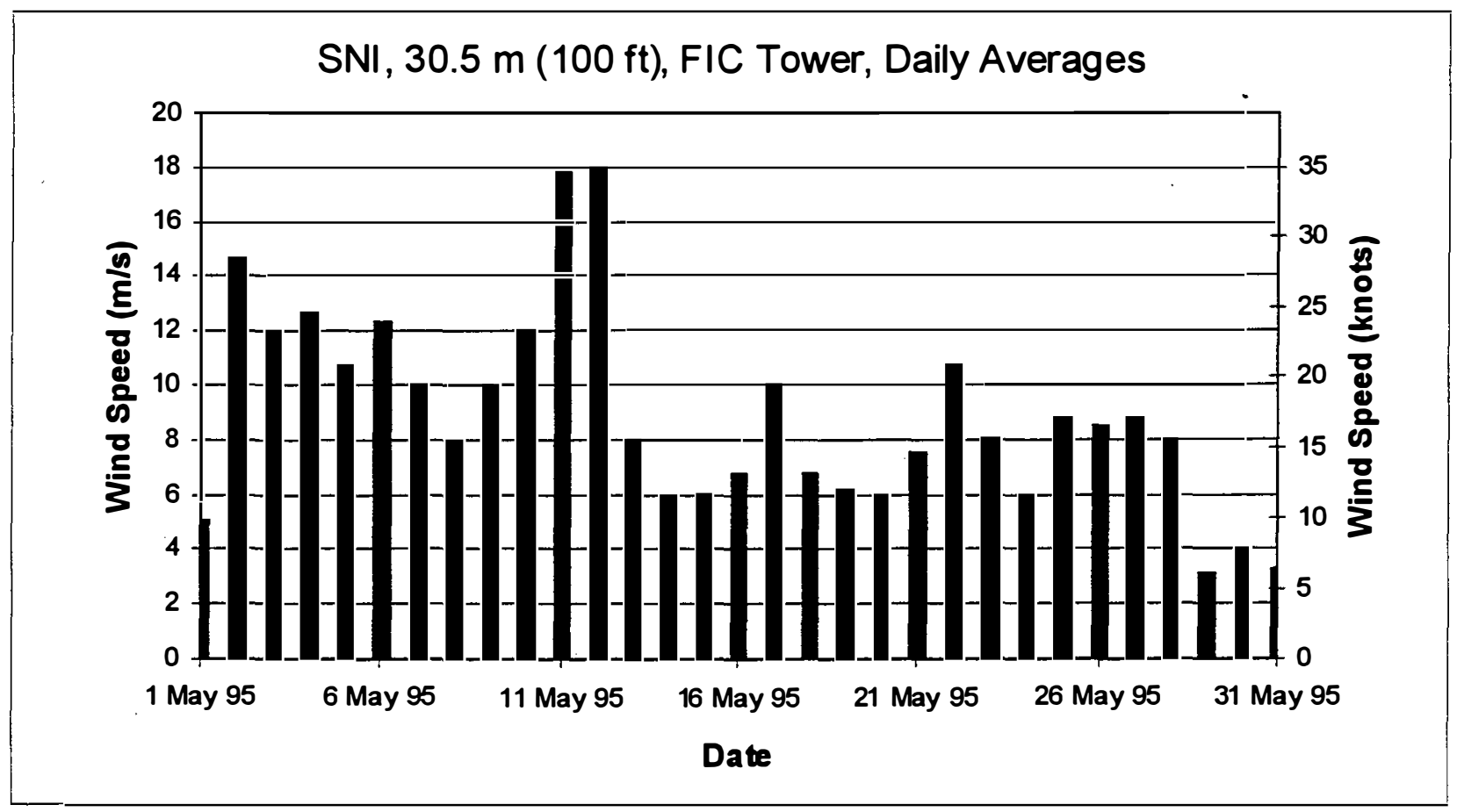

Figure B10: Wind Speed Record, May 1995 


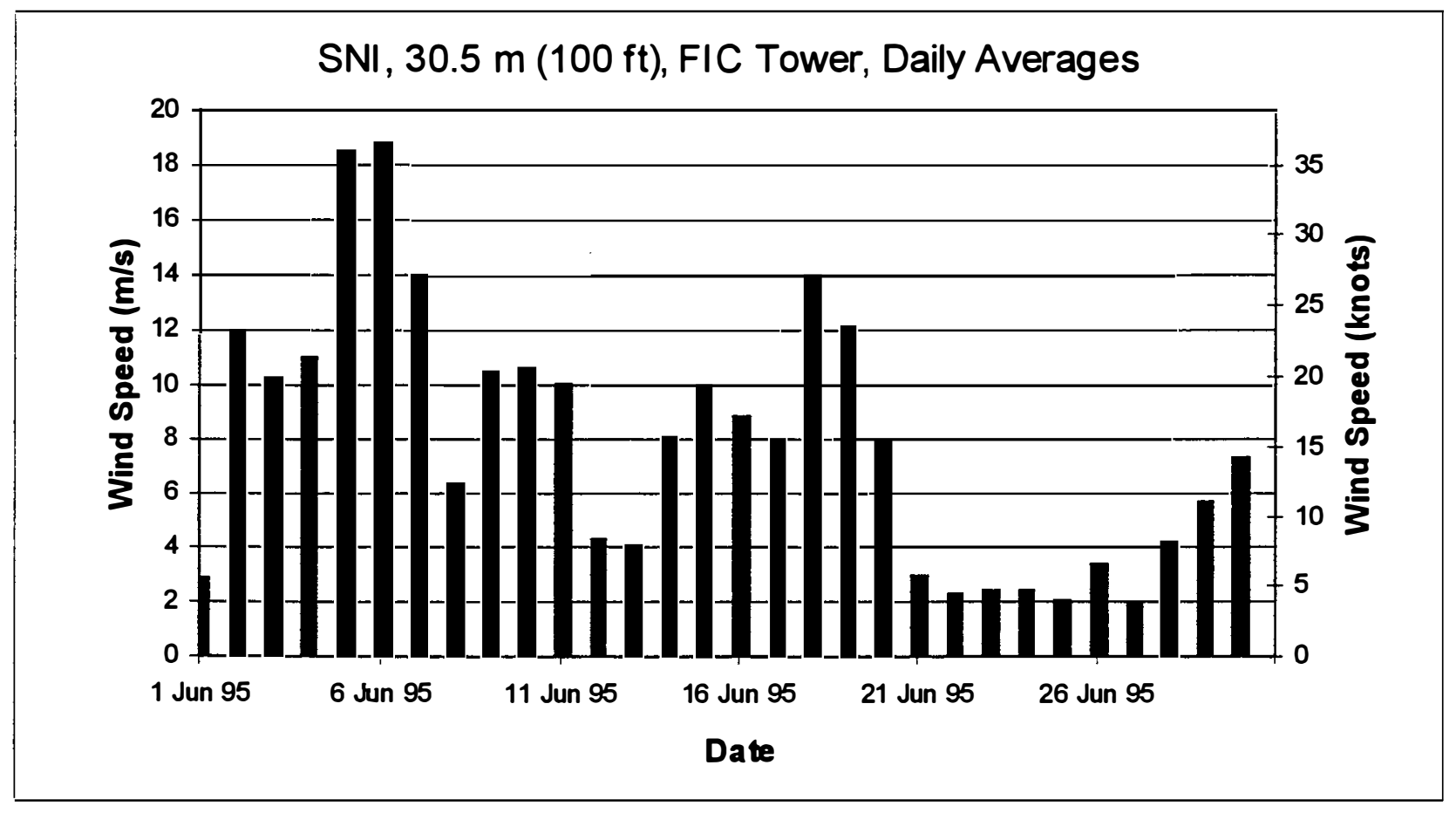

Figure B11：Wind Speed Record, June 1995

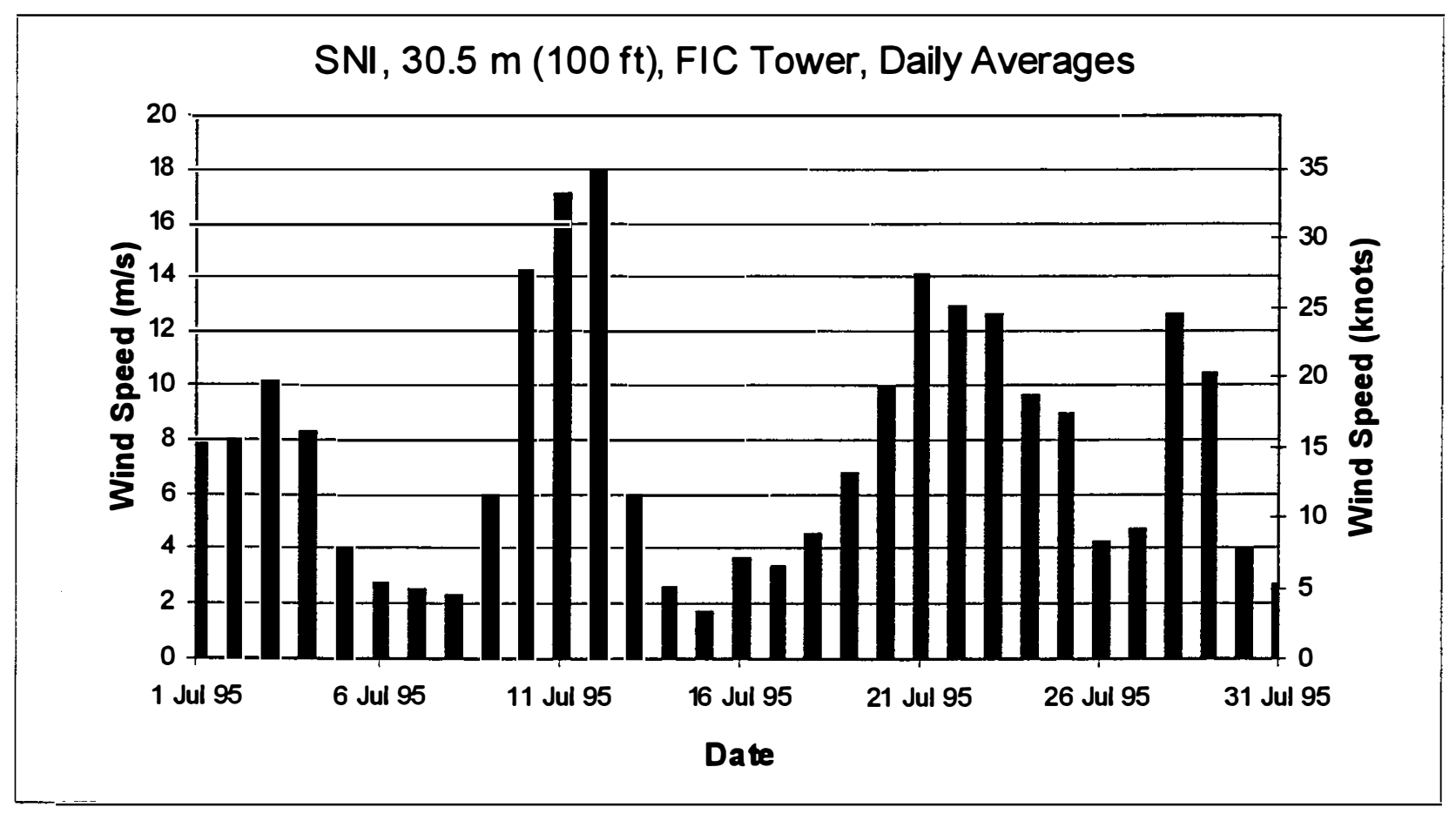

Figure B12: Wind Speed Record, July 1995 
APPENDIX C: Monthly Average Diurnal Wind Speeds 


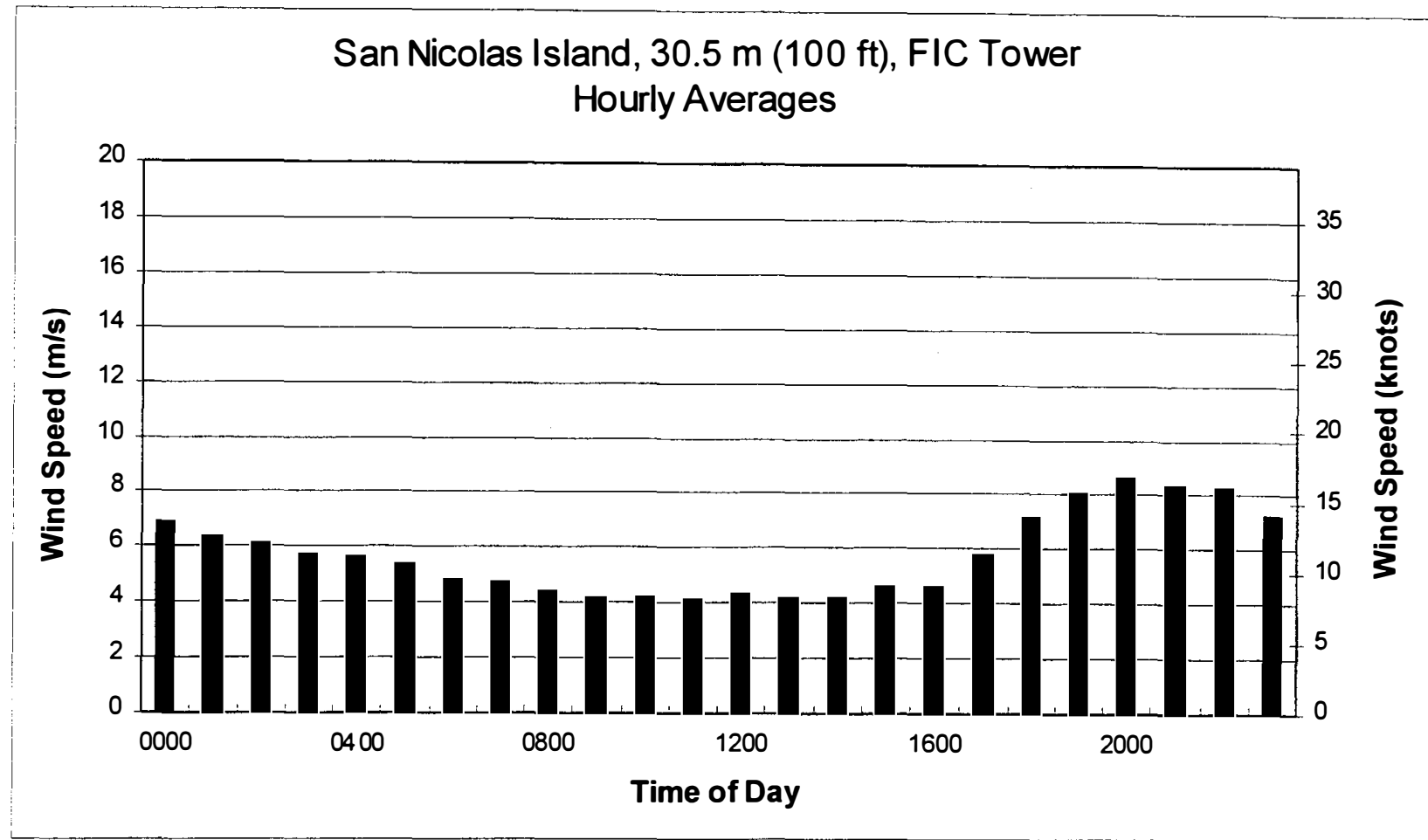

Figure C1: Diurnal Wind Speed, August 1994

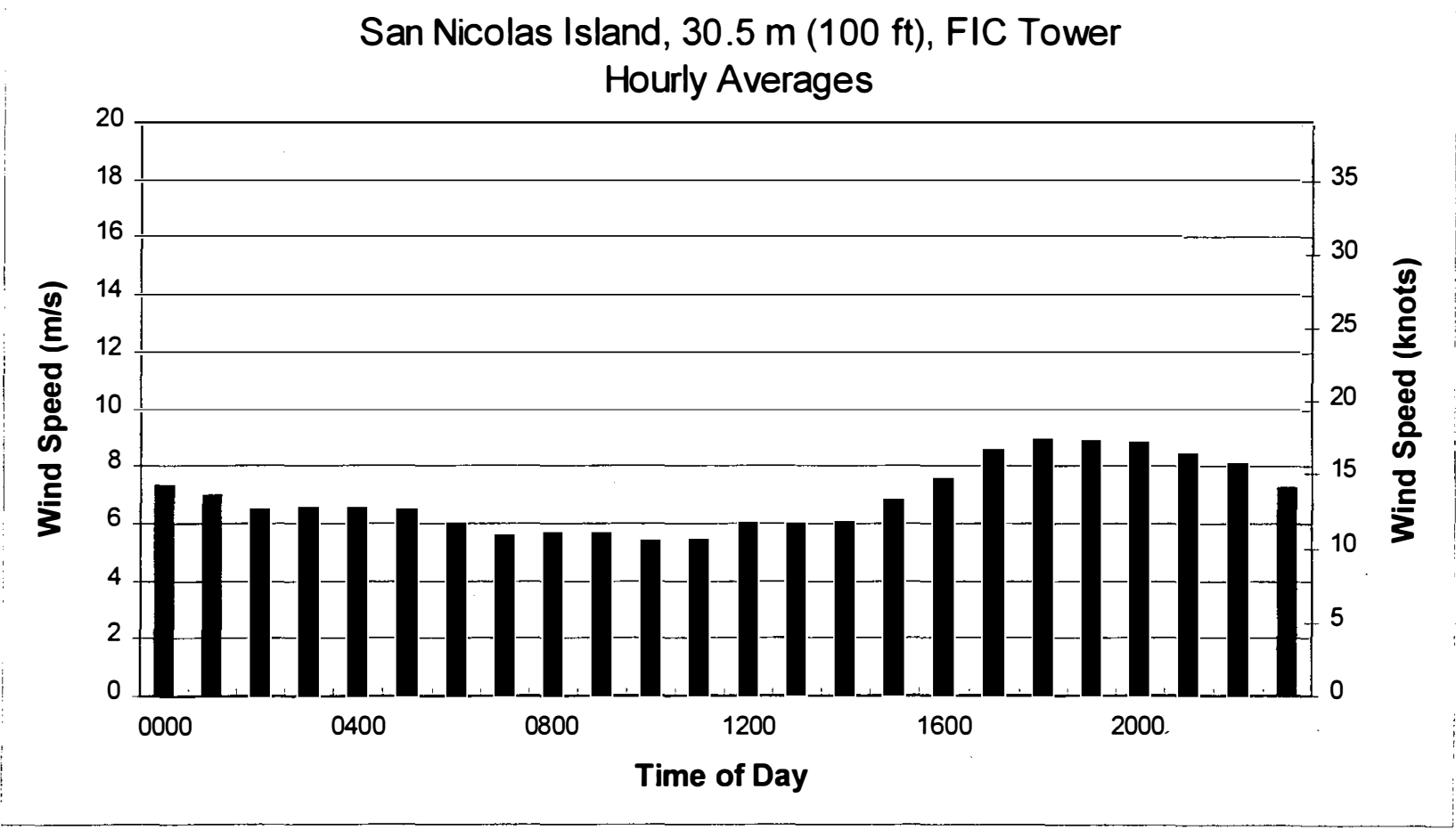

Figure C2: Diurnal Wind Speed, September 1994 


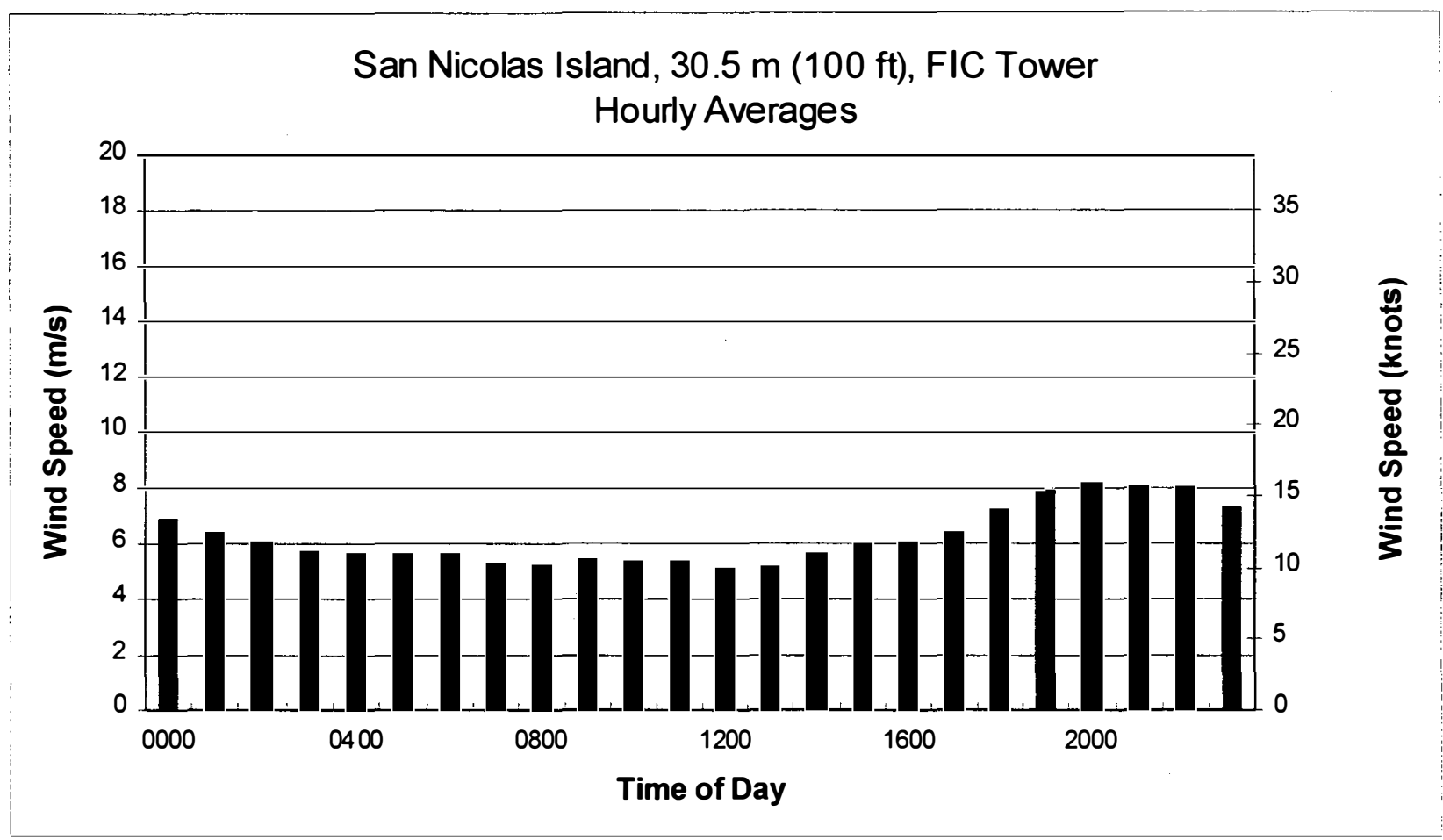

Figure C3: Diurnal Wind Speed, October 1994

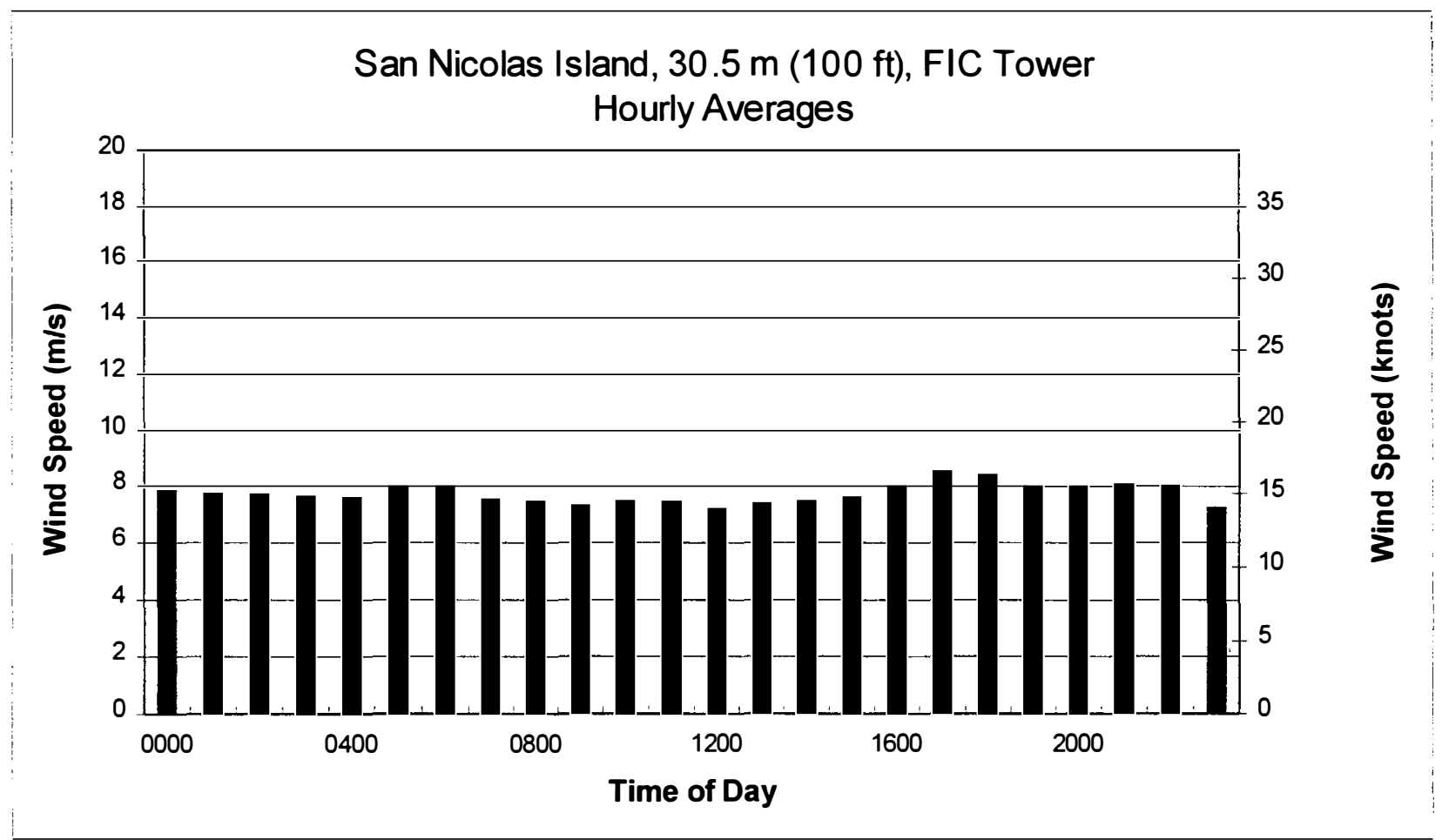

Figure C4: Diurnal Wind Speed, November 1994 


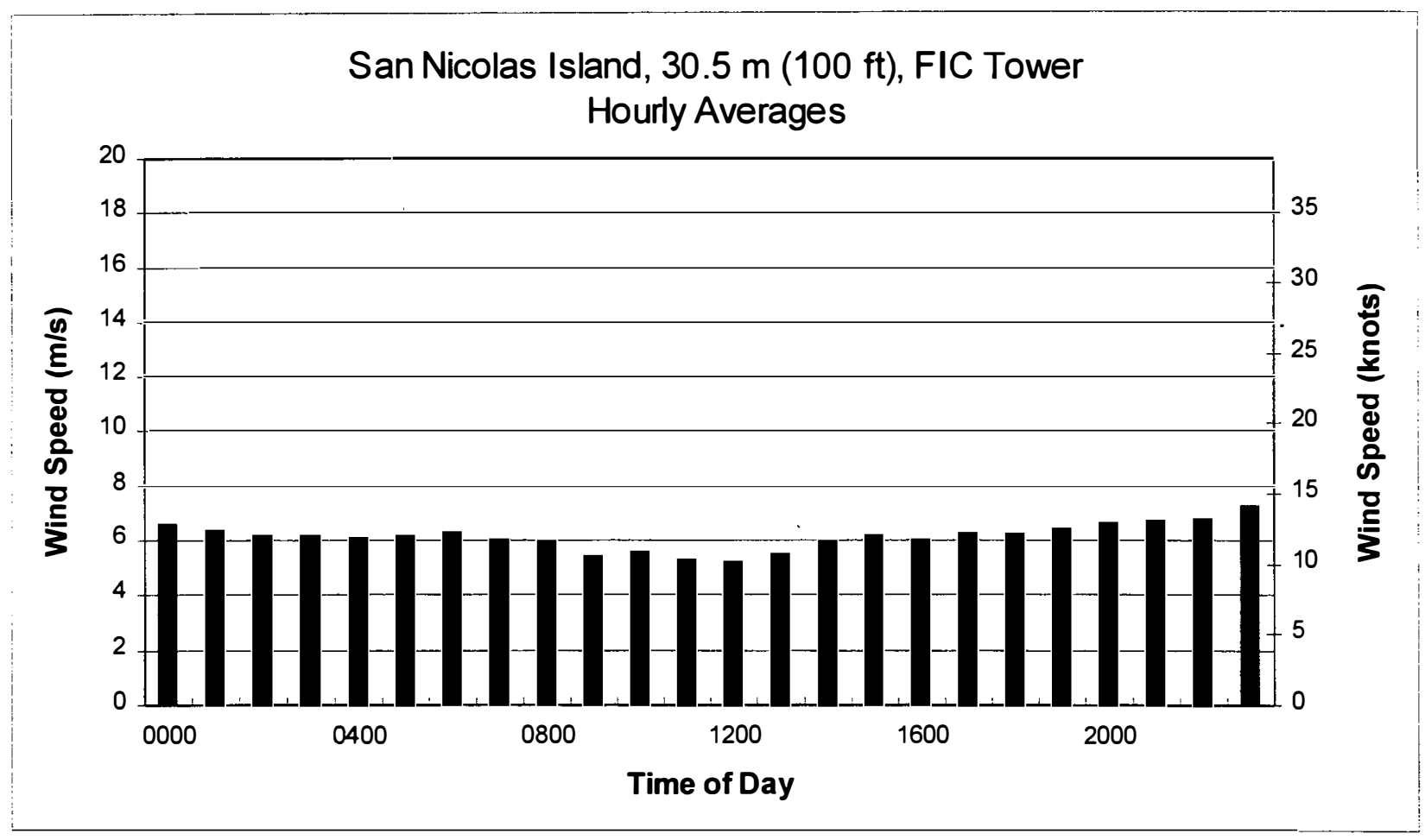

Figure C5: Diurnal Wind Speed, December 1994

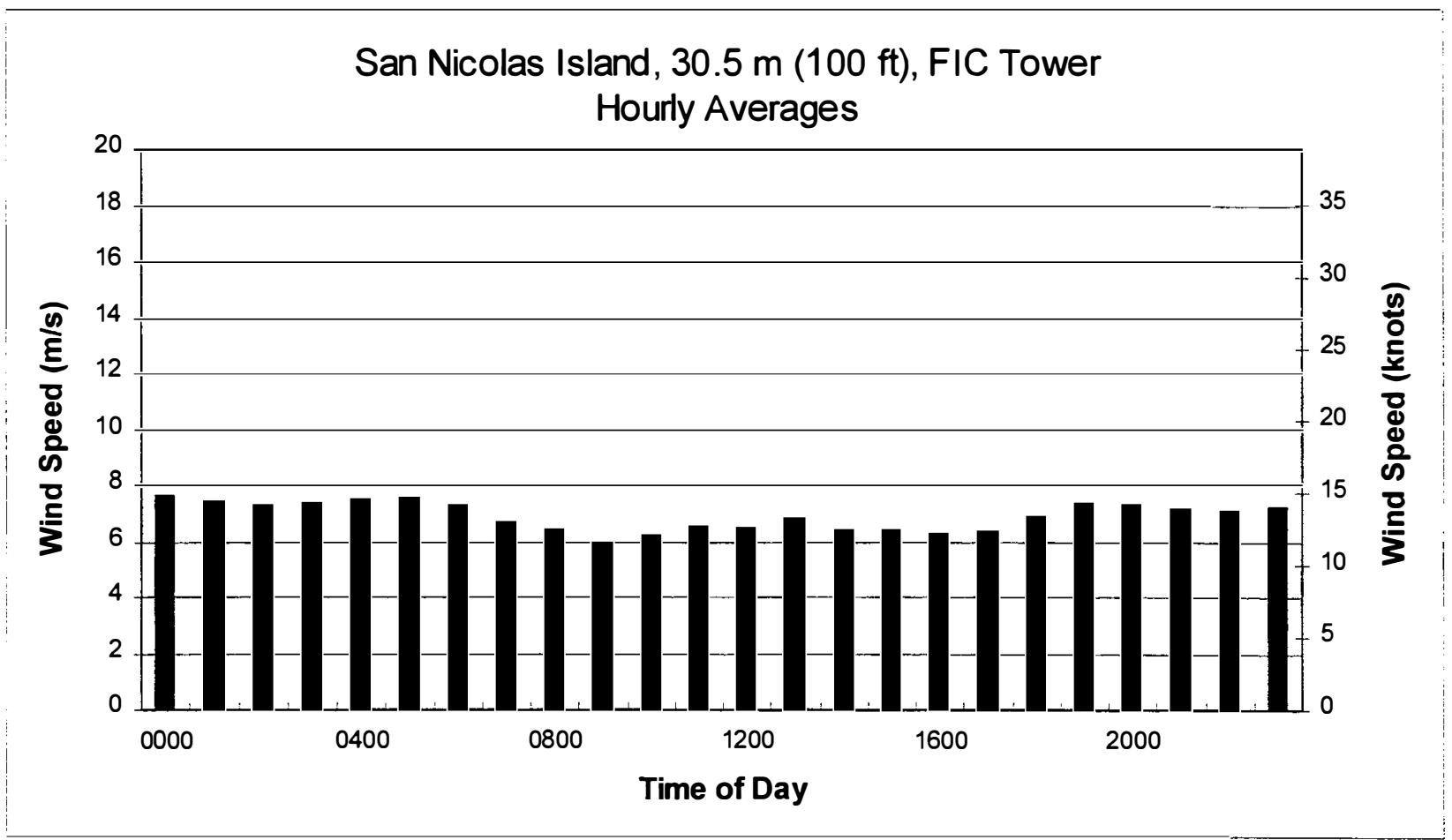

Figure C6: Diurnal Wind Speed, January 1995 


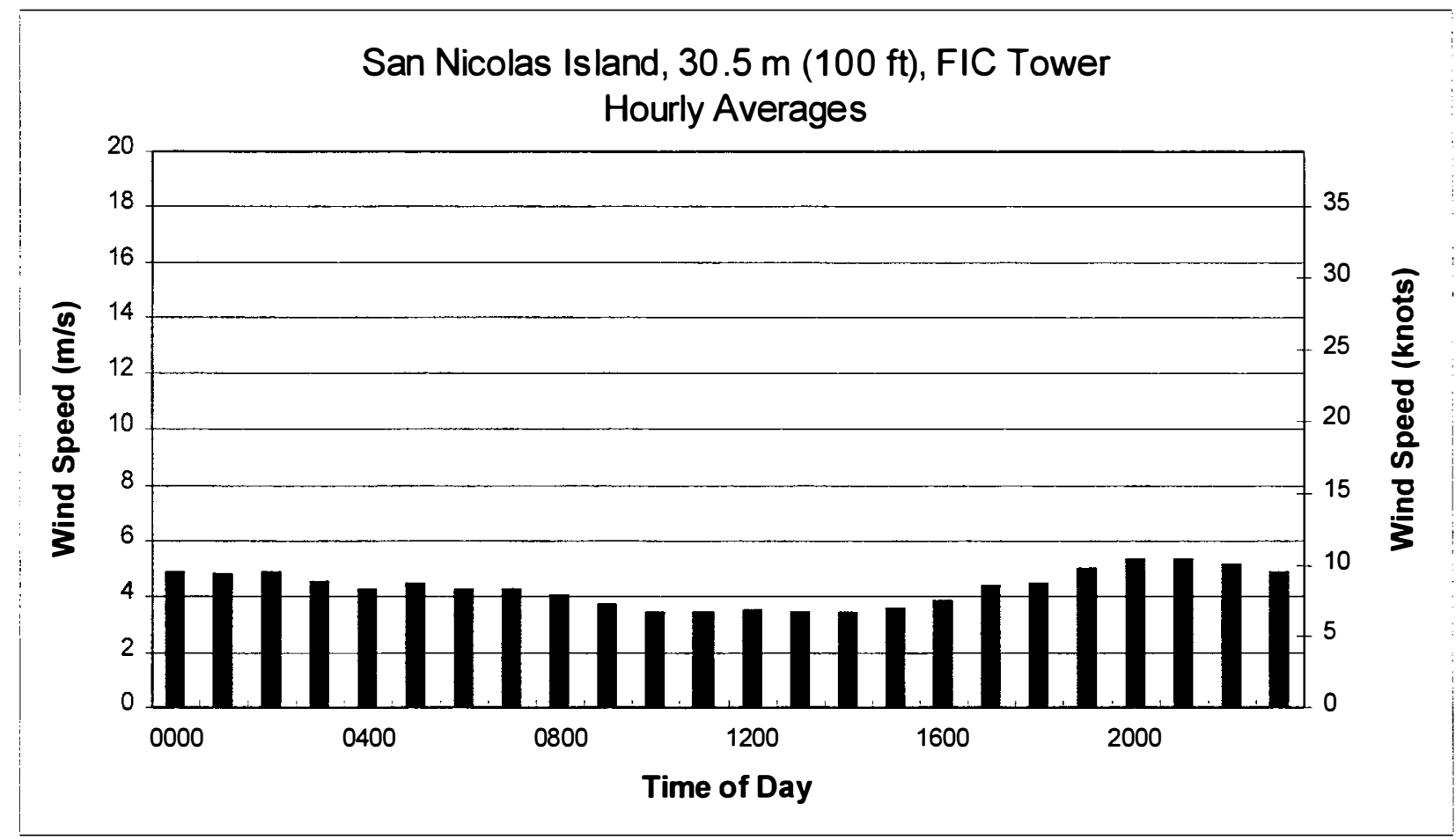

Figure C7: Diurnal Wind Speed, February 1995

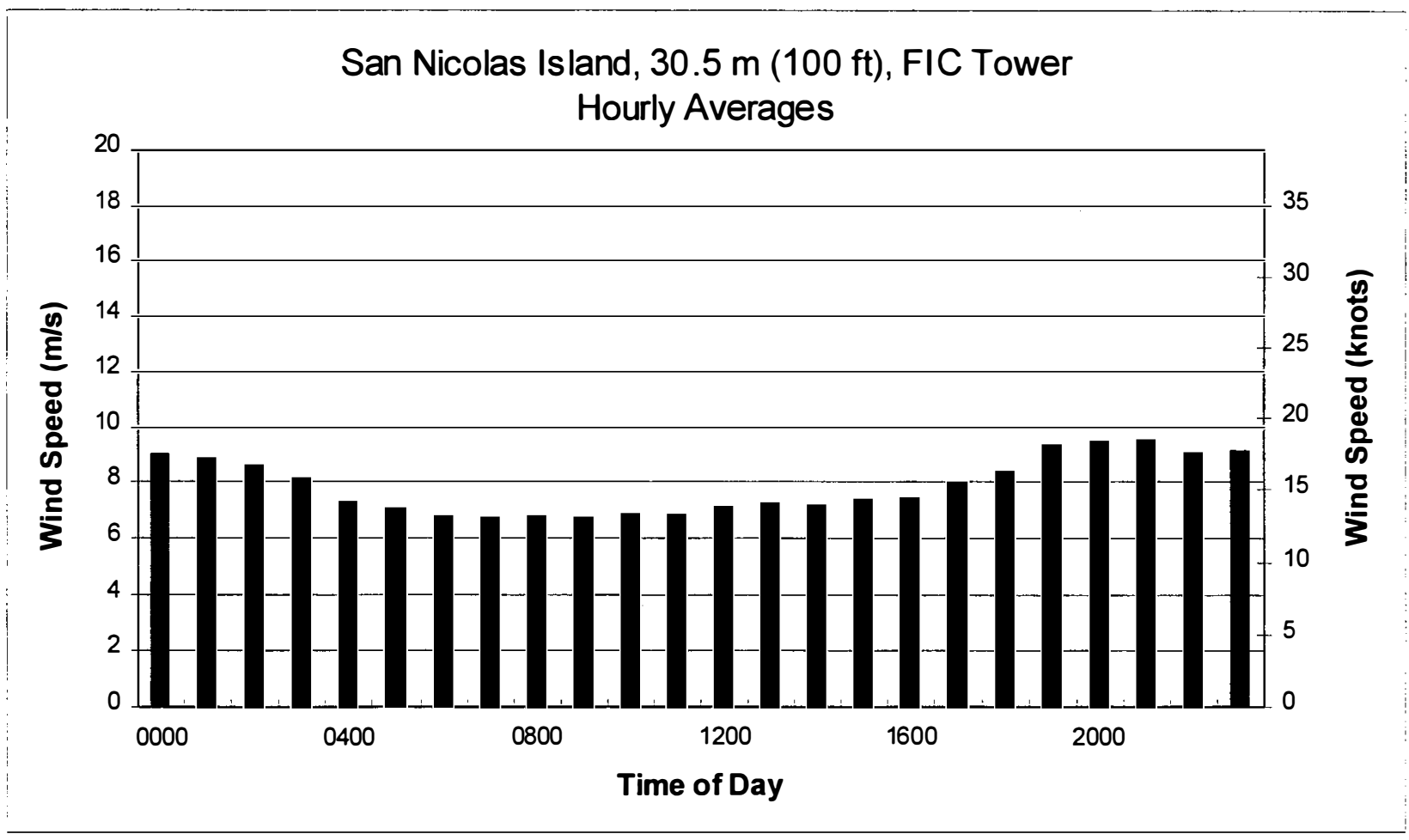

Figure C8: Diurnal Wind Speed, March 1995 


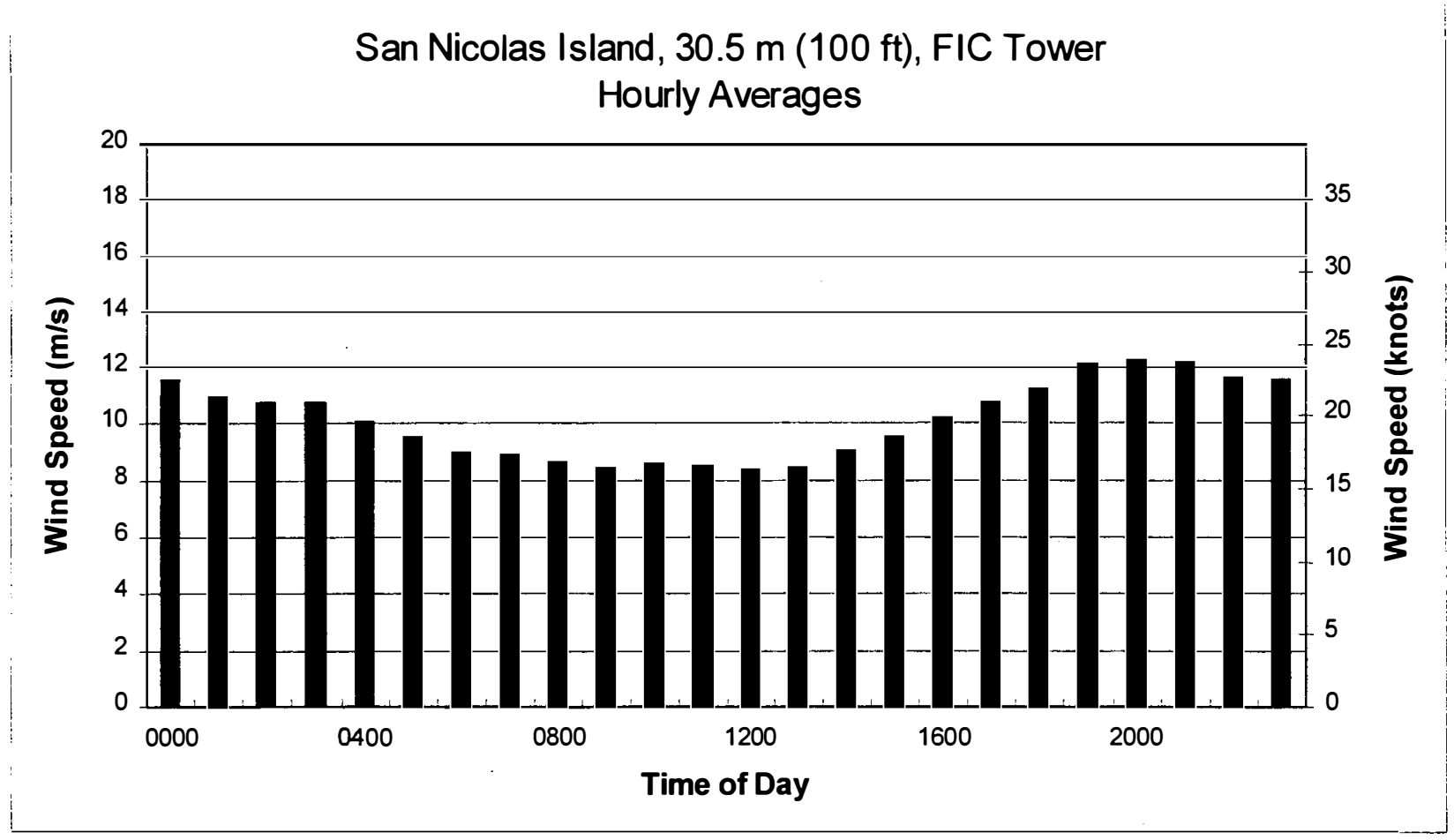

Figure C9: Diurnal Wind Speed, April 1995

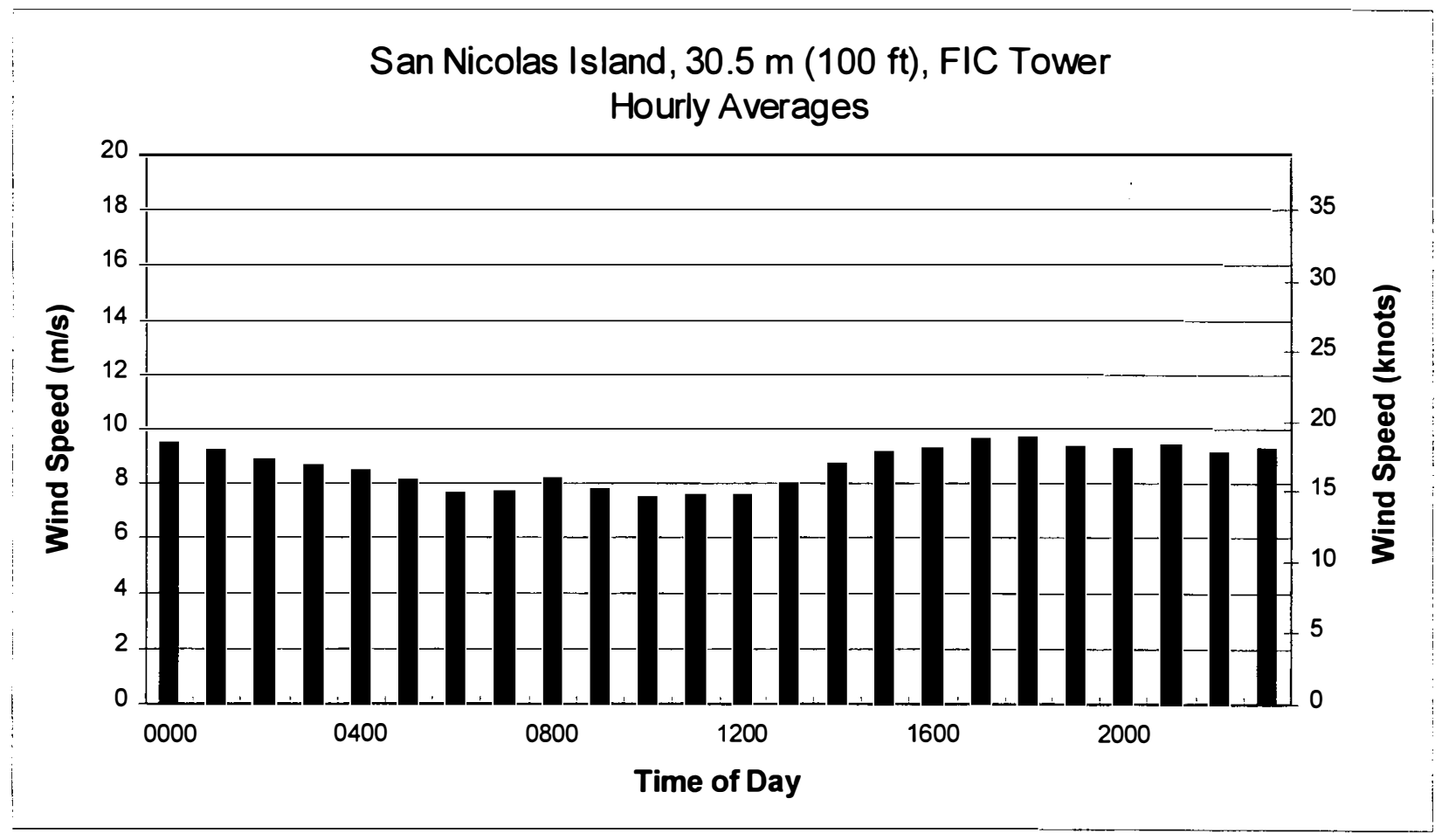

Figure C10: Diurnal Wind Speed, May 1995 


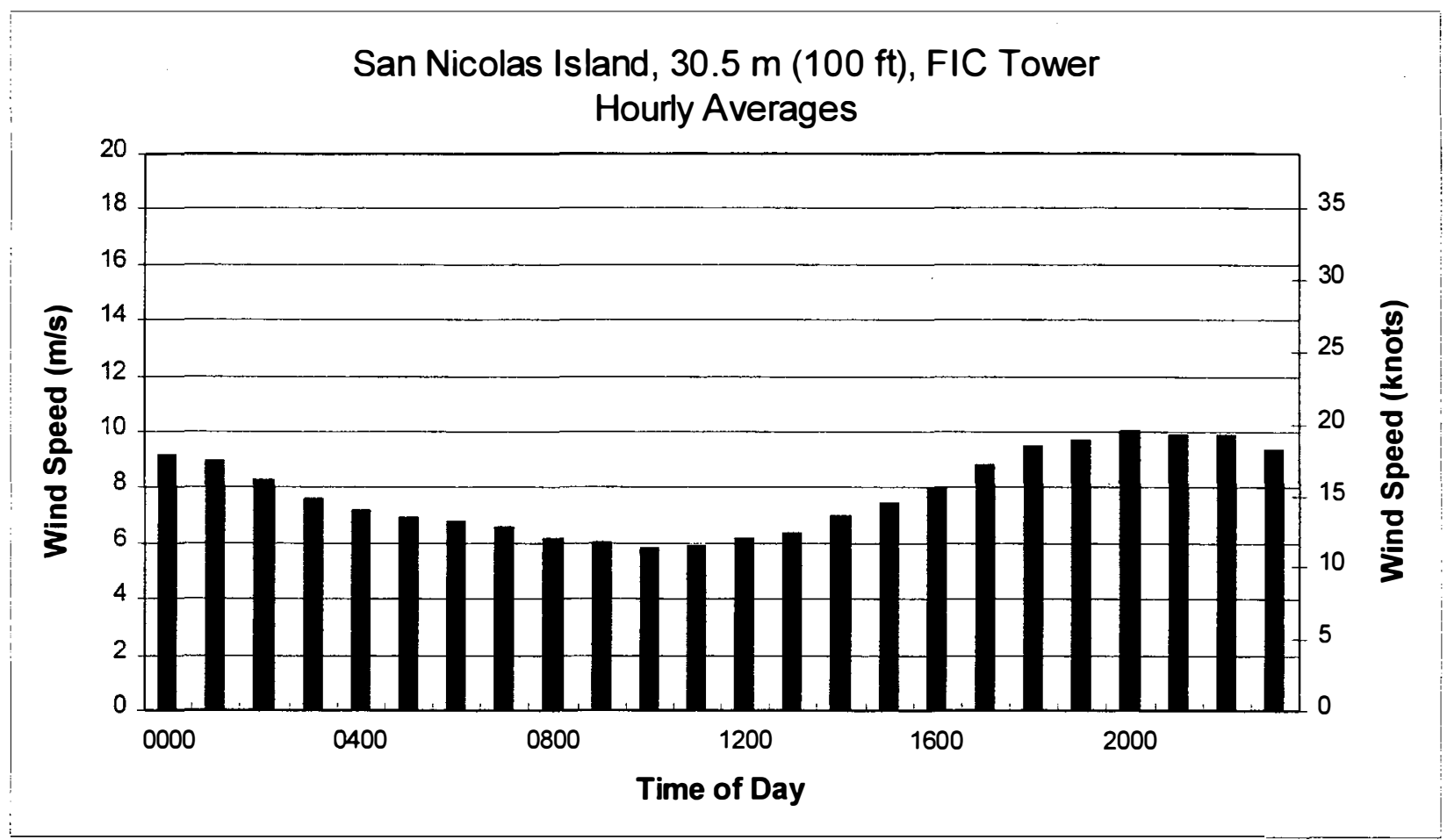

Figure C11: Diurnal Wind Speed, June 1995

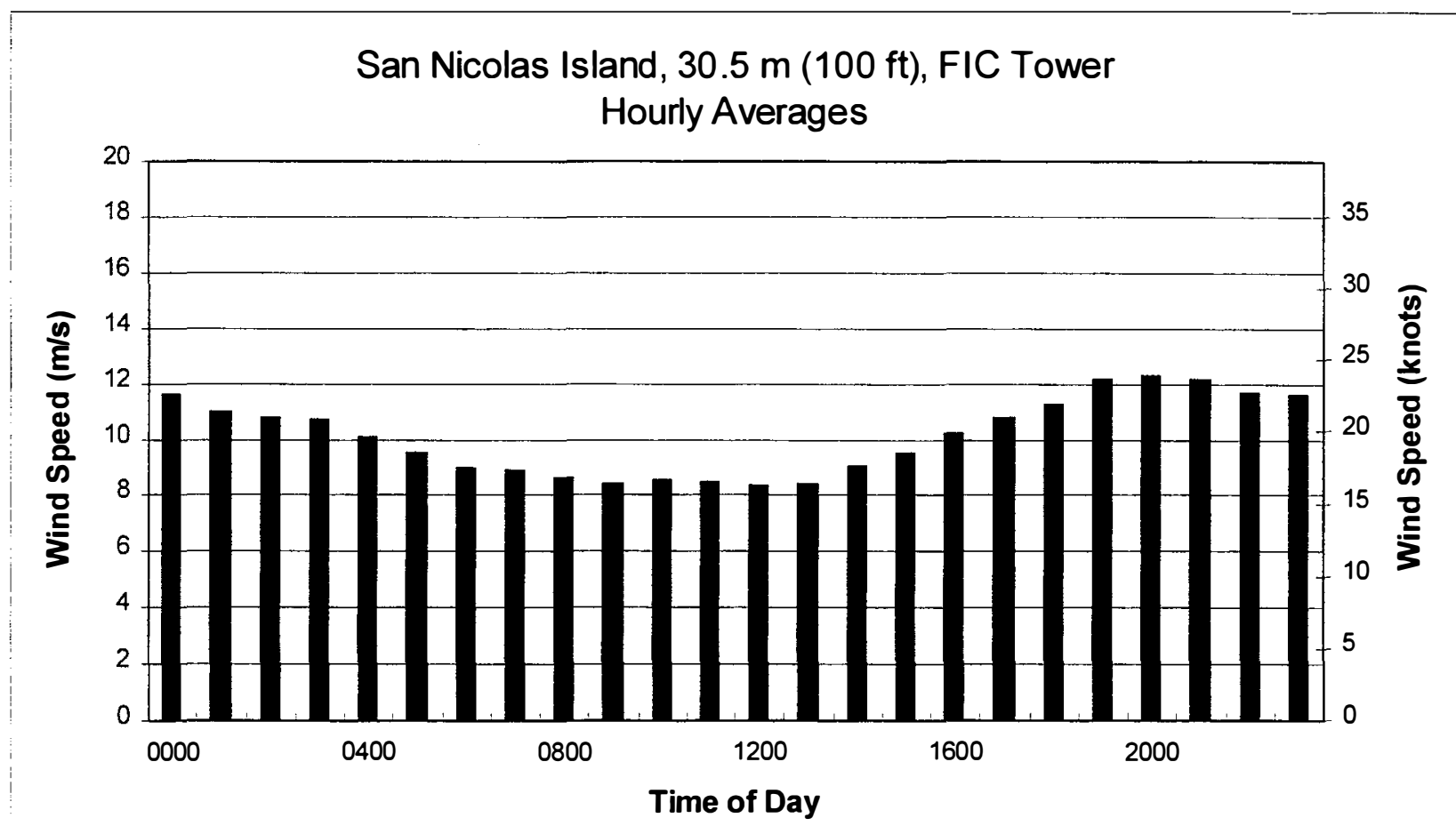

Figure C12: Diurnal Wind Speed, July 1995 


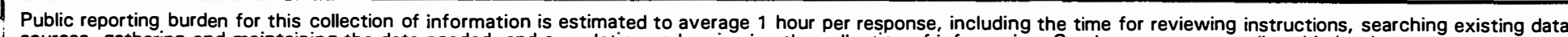

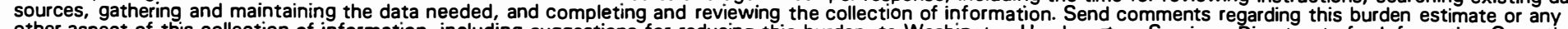

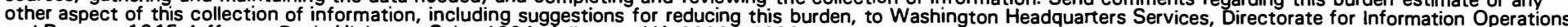

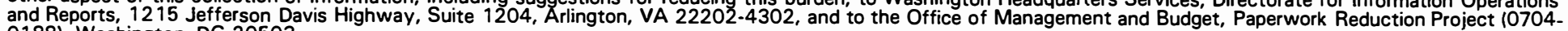
0188), Washington, DC 20503.

\begin{tabular}{|l|c|}
\hline 1. & $\begin{array}{c}\text { 2. REPORT DATE } \\
\text { January } 1996\end{array}$ \\
\hline
\end{tabular}

4. TITLE AND SUBTITLE

Wind Resource Assessment: San Nicolas Island, California

6. AUTHOR(S)

Ed McKenna, NREL

Timothy L. Olsen

Timothy L. Olsen Consulting

1428 S. Humboldt Street

Denver, CO 80210

7. PERFORMING ORGANIZATION NAME(S) AND ADDRESS(ES)

Timothy L. Olsen Consulting

1428 S. Humboldt Street

Denver, CO 80210

9. SPONSORING/MONITORING AGENCY NAME(S) AND ADDRESS(ES)

National Renewable Energy Laboratory

1617 Cole Blvd.

Golden, CO 80401-3393
3. REPORT TYPE AND DATES COVERED Subcontract Report

5. FUNDING NUMBERS

C: $C C D-5-15223$

TA: WF234401

8. PERFORMING ORGANIZATION REPORT NUMBER

1

\section{SUPPLEMENTARY NOTES}

NREL Technical Monitor: Ed McKenna

12a. DISTRIBUTION/AVAILABILITY STATEMENT National Technical information Service

U.S. Department of Commerce

5285 Port Royal Road

Springfield, VA 22161

12b. DISTRIBUTION CODE

UC-1212

13. ABSTRACT (Maximum 200 words)

The joint Department of Energy (DOE) and National Renewable Energy Laboratory (NREL) report was prepared as an account of work for others funding contract, sponsored by the Department of Defense (DoD) Strategic Environmental Research and Development Program (SERDP) under DOE Contract \#DE-AC02-83CH10093.

This report documents the wind resources on San Nicolas Island (SNI) from detailed field measurements collected for one year and coarse historical data collected over 32 years. This report will be used by DoD/United States Navy (USN) Naval Facilities Engineering Service Center (NEFSC) as input for additional economic and feasibility studies for a Wind-Diesel installation for SNI.

Timothy L. Olsen, Engineering Consultant, was contracted to provide data reduction analysis, research historical wind resource data, and assist with generation of this report.

14. SUBJECT TERMS

wind resource assessment; wind energy

17. SECURITY CLASSIFICATION OF REPORT

Unclassified
18. SECURITY CLASSIFICATION OF THIS PAGE Unclassified
19. SECURITY CLASSIFICATION OF ABSTRACT Unclassified
15. NUMBER OF PAGES

16. PRICE CODE

20. LIMITATION OF ABSTRACT

UL 